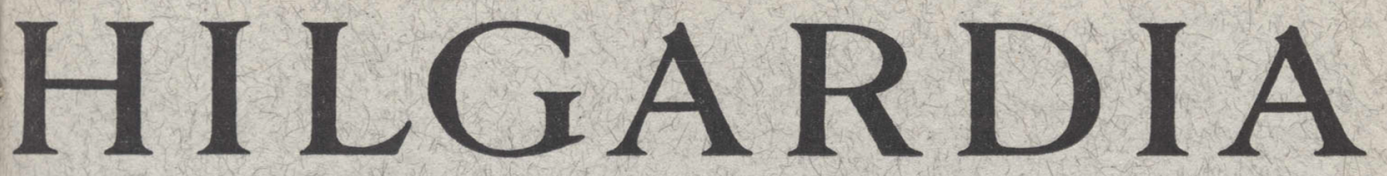

A Journal of Agricultural Science Published by the California Agricultural Experiment Station

\title{
ECOLOGY OF POCKET GOPHERS WITH EMPHASIS ON THOMOMYS BOTTAE MEWA
}

\author{
WALTER E. HOWARD \\ and \\ HENRY E. CHILDS, JR.
}

UNIVERSITY OF CALIFORNIA - BERKELEY, CALIFORNIA 
The life history and ecology of the Digger pine pocket gopher (Thomomys bottae mewa) are here reported. Most of the data were obtained by live-trapping for five years 330 marked individuals 1,798 times on a 3.7-acre study plot at the San Joaquin Experimental Range, O'Neals, California. In all, more than 1,000 gophers were studied, many of which were maintained in various types of laboratory cages.

Body weight is not a reliable indication of age since males continue to grow throughout their life and the alimentary tract of seven gophers averaged one fifth of their gross body weight.

Males do not live as long as females, which often live for three or four years.

Gophers apparently are frequently polygamous. The adult sex ratio of males to females varied from about $1: 1$ to $1: 4$. Females predominated (1:4) when the population density was high.

The home range of a pocket gopher is also its "territory," for adults vigorously defend their entire burrow system from others of both sexes, except during the breeding season. Male territories occupied an average surface area of 2,200 square feet, whereas females only one half that, or 1,300 square feet.

Young gophers often left home by dispersing aboveground. More than 200 were captured in funnel traps on the ground surface along hardwarecloth drift fences. Gophers released 200 or more feet from their burrow were able to return home by traveling through existing burrow systems.

The ecological factors responsible for creating fluctuations in the density of gophers are discussed. Also discussed are the signifiance of pocket gophers with respect to animal associates, soil and forage relationships, effect of burrows, and importance to man. 


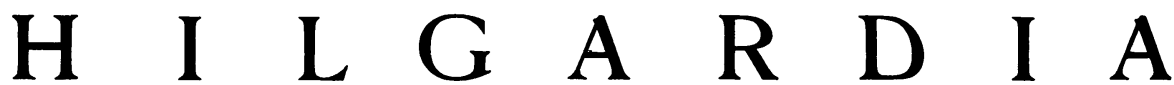

A Journal of Agricultural Science Published by

the California Agricultural Experiment Station

\begin{tabular}{lll}
\hline VoL. 29 & NOVEMBER, 1959 & No. 7 \\
\hline
\end{tabular}

\section{ECOLOGY OF POCKET GOPHERS WITH EMPHASIS ON THOMOMYS BOTTAE MEWA ${ }^{1}$}

\section{WALTER E. HOWARD ${ }^{2}$ and HENRY E. CHILDS, JR. ${ }^{3}$}

\section{INTRODUCTION}

Fossorial mammals are widely distributed throughout the world. In North America they are best represented by moles of the family Talpidae and by pocket gophers of the family Geomyidae. Both groups are of considerable economic importance, yet little is known of their population dynamies in comparison with the information available about other small mammals that spend more time aboveground.

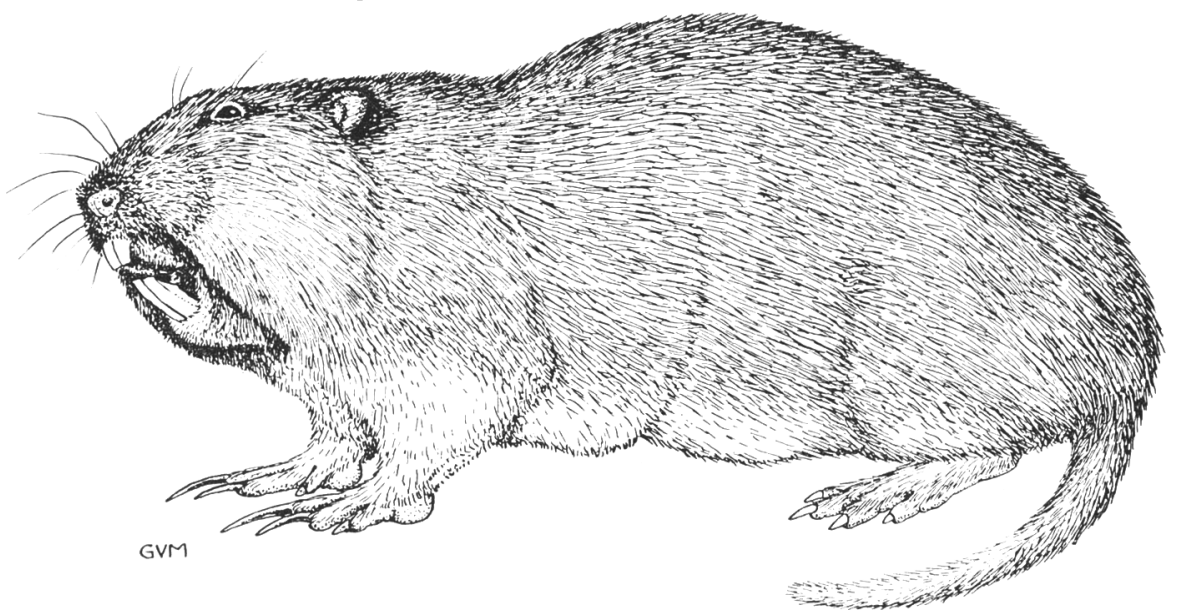

Fig. 1. A pocket gopher, Thomomys bottae. (Drawn by G. Victor Morejohn.)

There are three genera of pocket gophers in the United States, all of which belong to the family Geomyidae. The western pocket gopher (Thomomys) (fig. 1) occurs over most of western North America. The eastern pocket gopher (Geomys) is found on the plains and prairies and in the eastern Gulf states. The Mississippi pocket gopher (Cratogeomys) occurs from south-

${ }^{1}$ Submitted for publication April 26, 1958.

${ }^{2}$ Specialist, Field Station Administration, University of California, Davis.

${ }^{3}$ Instructor, Life Science Department, Cerritos College, Norwalk, California. 
eastern Colorado, eastern New Mexico, and western Oklahoma south through western Texas into Mexico. There are no gophers in northeastern United States.

Pocket gophers of the genus Thomomys are widely distributed over almost all of California from sea level to 13,000 feet. They are most abundant in better soils where food and cover are plentiful. In alfalfa fields populations of more than 50 adult gophers per acre may build up within a few years; on less favorable sites, such as foothill ranges, less than 10 adults per acre or none at all may be present. There are about 40 recognized kinds of gophers in California. Hooper (1941) lists the type localities of 266 forms of pocket gophers of the genus Thomomys.

An outline of information needed for an ecological life history of pocket gophers has already appeared (Howard and Ingles, 1951), and many of the references listed there are not cited here.

\section{GENERAL CHARACTERISTICS AND BEHAVIOR OF GOPHERS}

A pocket gopher is well adapted for life in burrows, having short, stout legs and powerful forearms (Holliger, 1916). It has three long claws on each forefoot for digging (fig. 2), fairly small eyes set far apart and high up on the head, and small external ears. The hairs on the tail are short except for a few guard hairs. There is a sparse scattering of long guard hairs over the rest of the body, particularly in the rump region. They presumably serve as sensory hairs that, along with the nearly naked tail, guide gophers in their dark tunnel systems, even when going backward. A detailed account of the morphology of the pocket gopher is provided by Hill (1937).

The pocket gopher gets the first part of its name from a pair of external, fur-lined cheek pouches, which they can turn inside-out. This is accomplished by muscles and the forefeet (Merriam, 1906). Two caged gophers have been observed with an everted pouch while asleep. Observations on gophers in glass-sided, dirt-filled cages revealed that when fighting in a burrow, pouches are sometimes everted. They are primarily used for carrying food and nesting material, but not for removing dirt.

The curved incisors of the pocket gopher are an amazing set of continuously growing, chisel-like teeth (fig. 2). They are located outside the mouth cavity, the lips encircling them in such a manner that they are still exposed even when the mouth is closed (Merriam, 1906). This adaptation enables an animal to cut roots or dig burrows without at the same time "eating" dirt. In adults the replacement growth of each upper incisor was found to be 9 inches a year, and 14 inches for each lower (Howard and Smith, 1952). The center three nails of each forefoot grow about 3.5 inches per year, which is almost twice that of all remaining fore and hind nails (Howard, 1953b).

Not much pertinent information was obtained to indicate food preference. All types of forage occurred in caches along with seeds, tubers, bulbs, and acorns. Gophers apparently eat a considerable amount of roughage; at least the gopher caecum is proportionately much larger than that of Citellus, 


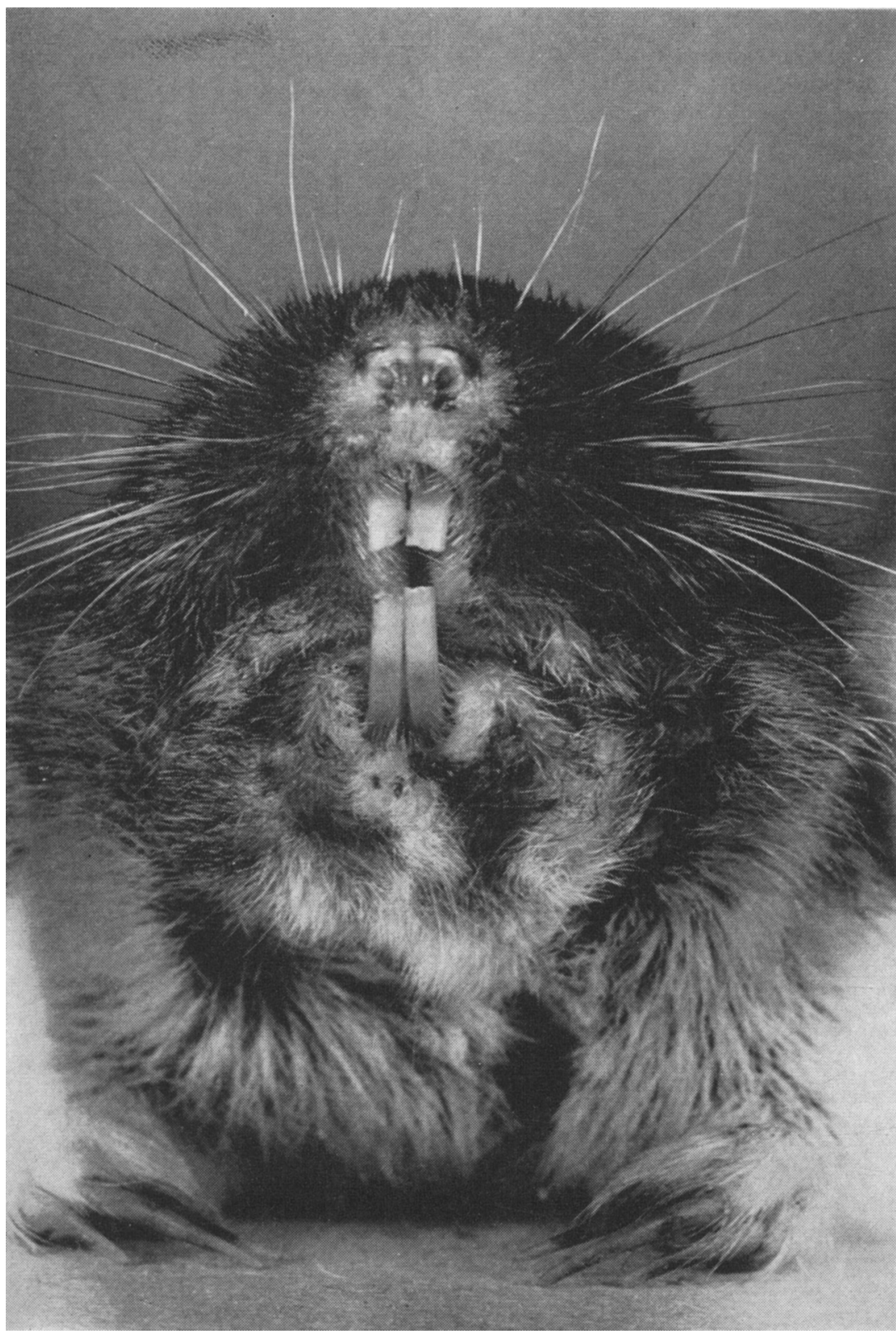

Fig. 2. The lips of a pocket gopher close behind the incisors.

Dipodomys, Perognathus, and Peromyscus. In a laboratory experiment it was found that the stomach contents of a gopher still retained some greenish color (grass?). after the animal had been fed exclusively on rolled oats for 
the previous 72 hours. Observations of caged gophers living in burrows under glass indicate that food caches are usually placed in sealed compartments, the short tunnels leading to such food being plugged with soil.

It was learned that gophers can be kept without water if some green or succulent food is supplied; on a diet of only rolled oats without water they would die, unless they were provided with a moist burrow system. One individual, for example, when caged and fed only rolled oats and no water, in a 10-day period dropped in weight from 76 grams to 54, a loss of 29 per cent. With the addition of water, however, its weight returned to 70 grams within six days. Gophers were found to consume considerably more feed during cool weather than in warm weather.

Pocket gophers in captivity seldom make vocal sounds. Occasionally they utter rather soft murmurs and squeaks; otherwise, the principal sound produced is a clicking of the teeth. Several dozen animals were confined in the laboratory in individual cages for a number of months. Occasionally, when one animal started to click its teeth, many others would also begin. It seemingly provides some form of communication. It may be only a warning signal, since a largely solitary subterranean mammal would not be likely to require an extensive means of communication.

Juveniles molt into all or much of their first adult summer pelage in April or May; breeding occurs from January to May at the Experimental Range, although most of the young are born about the first of March. After this molt is completed, it is no longer possible to determine age by the appearance of the pelage. Even though molt patterns are irregular and there is variation between individuals, there usually is a distinct summer pelage and a separate winter coat in the animals of this population. Frequently a new winter coat begins to replace summer hair in the head region before summer hair has replaced all of the previous winter coat on the rump, so that for a short time such animals possess parts of three coats. Sometimes the rump region never molts into a summer pelage and once a year changes from winter pelage to winter pelage (Morejohn and Howard, 1956).

There is a lack of burrowing activity during the dry summer period. The animals retreat to their less extensive but deeper tunnels, closing off the shallower ones to escape the heat. We suspect that the animals also estivate for short periods in this season, although this has not been proved.

Three different caged gophers were observed in a profound sleep. Unfortunately, in each instance the animal appeared dead rather than sleeping, so no records of heart beat, respiration, or body temperature were obtained to substantiate the presence of a torpid condition. One of these gophers was taken from its cage, carried across the room, placed on a scale, and its individual record withdrawn from the files before it awoke. Each animal awoke quickly and became fully active, indicating that it may have been asleep rather than torpid. English (1932) also reports that gophers (Geomys) sleep soundly.

The behavior of a trapped pocket gopher upon release is of interest. Unless placed directly in front of the entrance to the burrow, these animals often have difficulty locating it. Even then they sometimes fail to recognize their 
burrow and turn away and start out through the grass. Yet sometimes when this happens they seem to be able to locate a tunnel by some unknown means, for they quickly dig down to one. When released in their own tunnel they quickly disappear but return promptly with a load of soil. They usually plug the exposed opening to their tunnel system immediately after being released. This requires several loads of soil gathered but a short distance back in the tunnel.

\section{THE DIGGER PINE POCKET GOPHER}

An intensive investigation was made of one subspecies of gopher, the Digger pine pocket gopher, Thomomys bottae mewa (Merriam), in the fall of 1947 to the summer of 1954 at the San Joaquin Range, O'Neals, California.

According to Grinnell (1933), the range of the Digger pine pocket gopher is the "digger pine belt along western base of Sierra Nevada, from Chinese, Tuolumne County, south to vicinity of Kernville, Kern County (Bailey, N. Amer. Fauna, No. 39, 1915:50; Mus. Vert. Zool.). Altitudes of capture extend from 300 feet (as at La Grange, Stanislaus County) up to 5,300 feet (at Shaver Ranger Station, Fresno County). Life zone, characteristically Upper Sonoran, but the subspecies invades Transition locally. For most part, lives in gravelly or rocky ground on open or sparsely wooded slopes." The Digger pine gopher is a little smaller than most representatives of the genus, being about 6 to 8 inches long and weighing 3 to 4 ounces.

\section{THE STUDY AREA}

The San Joaquin Experimental Range at O'Neals is located in the granitic foothill area of the Sierra Nevada on the east side of the San Joaquin Valley, approximately in the geographical center of the state. A detailed description of the Experimental Range and its purpose is provided by 20 authors in a publication edited by Hutchison and Kotok (1942). The Range is maintained by the Forest Service, U.S. Department of Agriculture.

\section{Weather}

The climate is characterized in general by mild winters (with green forage) and high summer temperatures (with dry forage), and by a distinct winter rainy season from December through March and a comparatively rainless period from May through September (fig. 3). Snow is rare. Maximum daily temperatures often exceed $100^{\circ} \mathrm{F}$ from early June to the middle of September. In the winter, daily minimum temperatures are frequently as low as 20 to $25^{\circ} \mathrm{F}$. In the years 1934 to 1954 , inclusive, precipitation averaged 19.4 inches annually, but there is considerable annual variation in rainfall. For example, the minimum rainfall during this period was 12.25 inches in 1938-39; the maximum precipitation was 32.09 inches in 1937-38. The monthly mean air temperatures and accumulative monthly rainfall are compared for the different years during this study (fig. 4). 


\section{Vegetation}

The Experimental Range location is in the Digger pine-blue oak association of the Upper Sonoran Life Zone, a woodland-grass association with scattered shrubs and dense patches of brush. There are fields of open grassland, several of which were formerly cultivated, but for the most part the area is characterized by a scattering of blue oak (Quercus Douglasii H. \& A.), in-

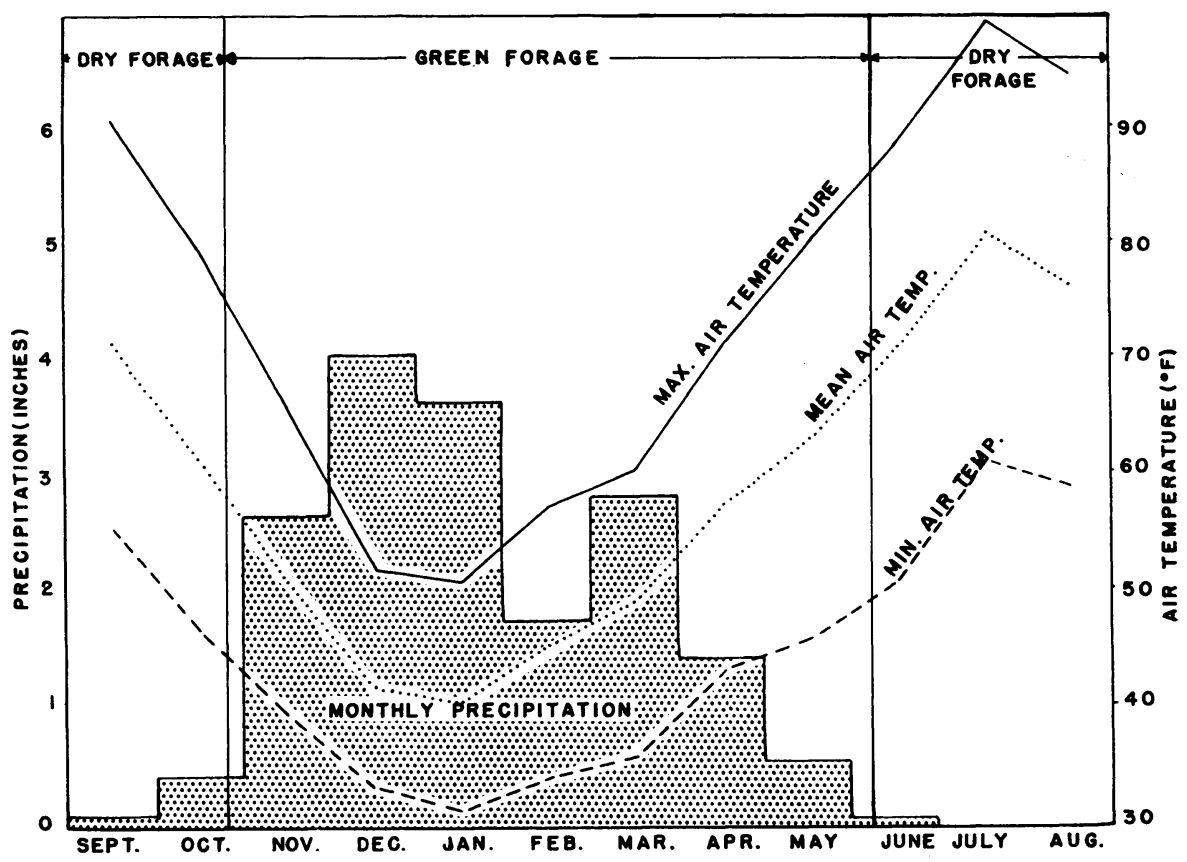

Fig. 3. The relation of green and dry forage to monthly precipitation and air temperatures at the San Joaquin Experimental Range. This is an average of five years-September, 1948 to August, 1953. (After Bentley and Talbot, 1951.)

terior live oak (Quercus Wislizenii A. DC.), Digger pine (Pinus sabiniana Dougl.), and brush consisting mainly of wedgeleaf ceanothus (Ceanothus cuneatus (Hook) Nutt.) and some Mariposa manzanita (Arctostaphylos mariposa Dudley).

Annual plants constitute about 99 per cent of the herbaceous cover at the Experimental Range. Over 60 per cent of these are introduced from the Old World (Talbot and Biswell, 1942). More than half of the herbaceous forage consists of broad-leaf filaree (Erodium botrys Bertol), soft chess (Bromus mollis L.), and foxtail fescue (Festuca megalura Nutt.), although at least 250 species of grasses and forbs are represented. The forage cover on much of California's foothill range differs from that on other western rangelands in that it is essentially of an annual type (Bentley and Talbot, 1948). It differs in species composition, time of growth, and utilization by 

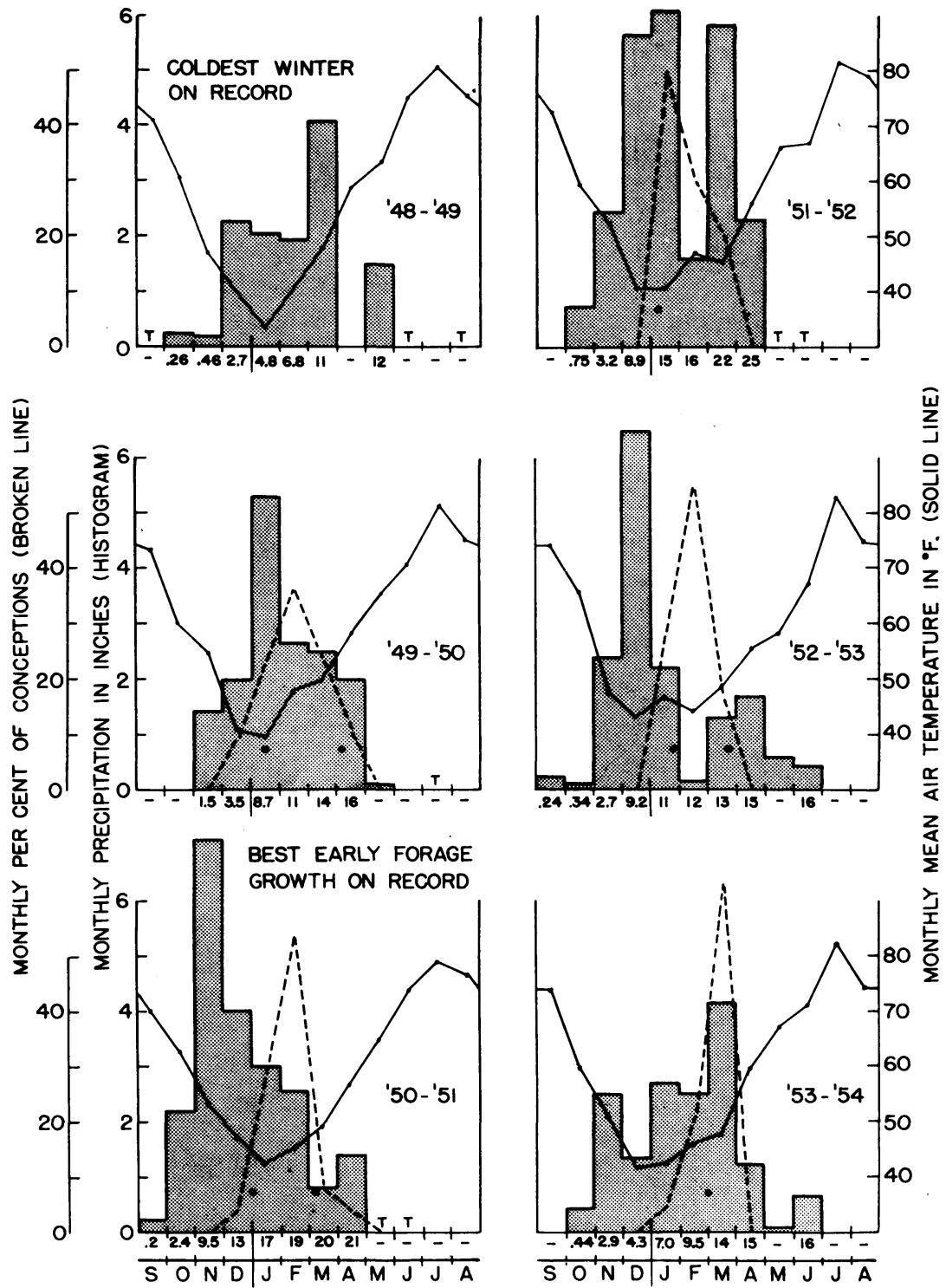

Fig. 4. Monthly precipitation and monthly mean air temperature at San Joaquin Experimental Range and per cent of conceptions occurring each month in female gophers on plot. Accumulative precipitation in inches for each of the six 12-month periods beginning with 1948-1949 was: $12,16,21,25,16$, and 16 . Note exceptionally low rainfall of 12 inches in 1948-1949. Dots indicate mean dates when vaginas of gophers were first observed open and when they were found open for the last time that season.

livestock. Foothill ranges supporting this distinctive herbaceous cover occur in a continuous belt around the Central Valley and in other areas in the north and south Coast ranges of California. 


\section{METHODS}

\section{The Field Plot}

After preliminary studies were completed, a special area, 3.7 acres in extent, subsequently called the "plot," was chosen for intensive study of pocket gophers (fig. 5). Most of the data upon which this report is based was obtained there. Trapping was intensive from May, 1949, to April, 1953.

From the fall of 1947 to the summer of 1954, about 1,100 individual pocket gophers were handled at least once at the San Joaquin Experimental

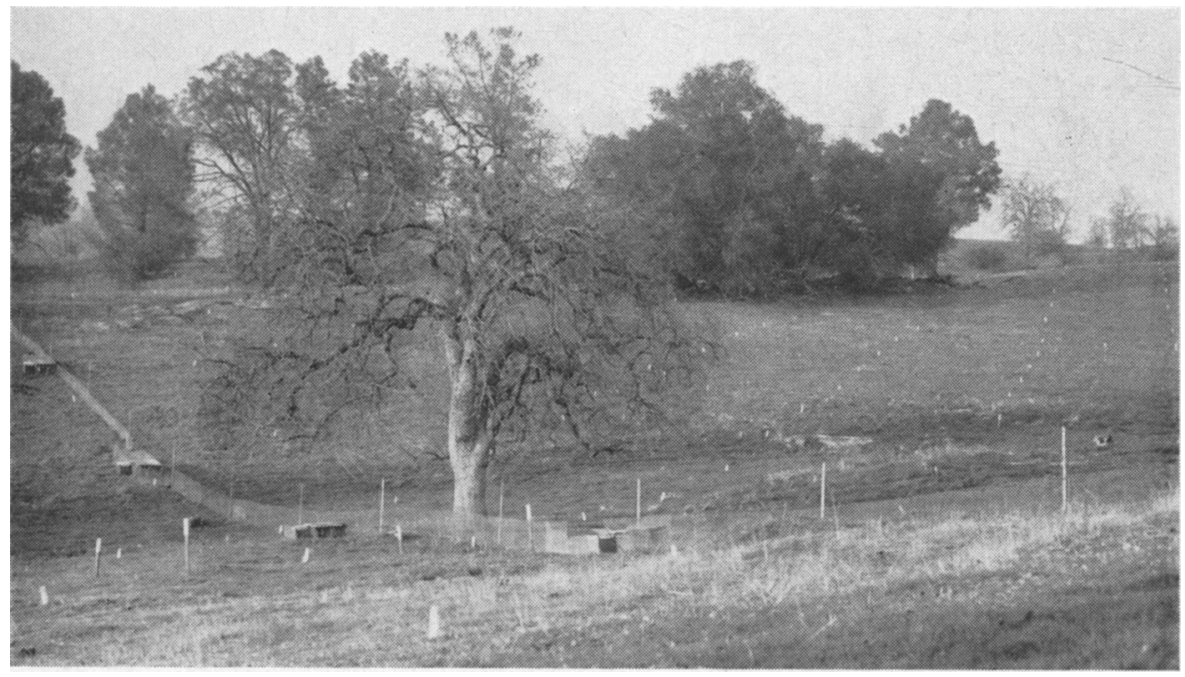

Fig. 5. About one third of the 3.7-acre, pocket gopher study plot is visible. Short stakes are at 20 -foot intervals. Four of the six drift traps and the drift fence can be seen.

Range. On the plot, 330 gophers were live-trapped 1,798 times, averaging 5.4 captures per gopher. As an adjunct to the live-trapping, more than 500 pocket gophers were kill-trapped in the last two years of the study. Most of them were collected adjacent to the study plot. They provided information on reproduction, food habits, and molt-data that could not be obtained from living animals. Many gophers also were studied while confined in various types of cages and pens.

To determine the size of the home ranges and territories of small mammals, a study area should be large enough to keep results from being affected too much by movements on and off the plot, and to furnish an adequate number of individuals. Blair (1941) recommends an area 10 to 20 times the size of the home range. Chitty (1952) thought an area about 40 times the size of the home range was desirable for his study on vole mortality. In the gopher study the plot was about 80 times the size of the female home range and about 40 times that of the male. In addition, considerable trapping was also done around the periphery of the plot. A larger area 
would be impractical to operate, and analysis of data indicates that the plot was sufficiently large to provide enough animals for obtaining reliable averages.

The plot was intended to represent conditions found in the vicinity of the Experimental Range. Slopes differing in direction of exposure are included in the plot as are swales and hilltops. Trees of the dominant species, Digger pine and blue and live oaks, are present as well as wedgeleaf ceanothus, which is the most common brush species. A swale in which water runs during some winters passes through the plot in a southwesterly direction. In addition to this swale, there is another smaller one in the northwest corner. A lightly used dirt road runs through the plot from north to south. In elevation the plot ranges from 1,187 to 1,230 feet.

The gopher plot presumably was uncultivated before 1938 and was used only as pasturage. During the next few years portions of the plot were used in reseeding trials; cork oaks were unsuccessfully tried in part of the area east of the road. Any effect these plantings had on the soil and forage growth seemed to have been completely dissipated long before the gopher project was started. During the course of the gopher study and for the five years preceding it the entire plot was used as a range for eattle. It was grazed intentionally each year so that it would resemble surrounding rangelands. This was thought desirable because most foothill land is now grazed or put to some form of agricultural use, with but a small percentage found in parks or other preserves.

\section{Grid System}

The pocket gopher presents problems of study peculiar to all fossorial rodents. Most of its activities are restricted to a burrow system, and to eatch the animal one must place a trap in that system. Thus it is impossible to space traps at uniform intervals in a quadrat, as has been done by Blair (1941) and others in their trapping of small nonfossorial rodents. To avoid excessive disturbance of the soil, traps were set only where gophers were known to be active. The easiest means of locating occupied burrow systems was to probe with a stiff wire where there had been recent digging activity by a gopher.

The plot was staked in a grid pattern with the stakes spaced 20 feet apart; one coördinate was indicated on the stakes by numbers, the other by letters. Exact trap sites could thus be recorded. When a gopher was captured, the trap position was carefully estimated to the nearest foot on both coördinates and written on the aluminum trap in ink or pencil. By beginning the grid system with letter $\mathrm{C}$ and number 19, animals that had moved only a few squares off the plot could still be trapped and recorded without ('hanging the system.

\section{Trapping}

The Macabee gopher trap was used for kill-trapping. The model of live trap used has been described by Howard (1952). The primary advantage of this particular live trap is that part of the trigger mechanism projects 
through the top, making is possible to tell whether or not the trap has been sprung without uncovering it. It takes longer to set live traps than Macabees, but live-trapping provided more animals per day per trap set than did the kill traps. However, one person cannot effectively operate more than about 40 of these live traps at one time, even during the peak of activity when fresh mounds are easy to locate. If the traps are checked several times a day, the number used must often be less.

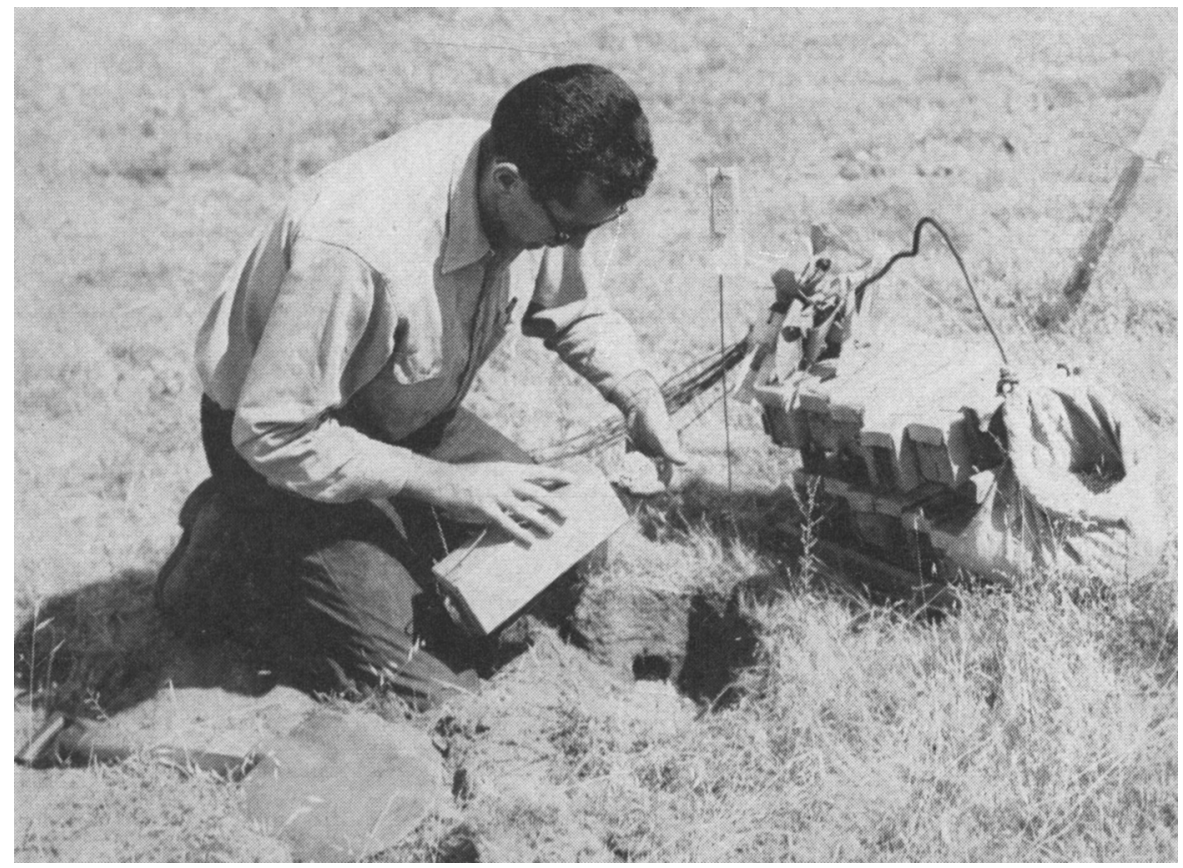

Fig. 6. Placing rolled grain in a pocket gopher live trap prior to setting it opposite exposed burrow.

Active burrow systems are recognized by the conspicuous mounds of fresh earth gophers bring to the surface. Since burrowing is done irregularly, it often is necessary to look for burrows in the vicinity of old mounds. After a tunnel is exposed with a shovel, a small handful of rolled grain is tossed back into the burrow as "forebait" (fig. 6). Another handful of bait is placed in the trap both to attract gophers and to provide food to keep trapped individuals from dying of "cold weather starvation" which results when there is insufficient food to maintain body temperature (Howard, 1951). Even if bait is not used when trapping gophers, animals are still captured as they attempt to fill the trap with soil; however, with bait more gophers are caught.

Gophers usually do not develop trap shyness, although a few individuals may be difficult to catch. These can sometimes be caught by plugging both 
the tunnel and trap entrance with a mixture of dirt and bait at the time the trap is set. Then, when the gopher digs for the food, he also digs himself into the trap. When setting a trap it is important to move it back and forth to work soil up through the hardware cloth floor of the trap. The trap should be placed on the level and soil carefully packed over it once it is in place.

TABLE 1

POCKET GOPHERS WHICH DIED DURING LIVE-TRAPPING OPERATIONS ON STUDY PIOT AND THOSE REMOVED FOR OTHER REASONS

IN 1953 AND 1954

\begin{tabular}{|c|c|c|c|c|c|c|}
\hline \multirow{3}{*}{ Year } & \multicolumn{4}{|c|}{ Died in traps } & \multirow{3}{*}{ Total } & \multirow{3}{*}{$\begin{array}{l}\text { Per cent } \\
\text { of total } \\
\text { population }\end{array}$} \\
\hline & \multicolumn{2}{|c|}{ Adults } & \multicolumn{2}{|c|}{ Young of year } & & \\
\hline & Males & Females & Males & Females & & \\
\hline May-Dec., 1949. & 0 & 2 & 0 & 0 & 2 & 2.7 \\
\hline $1950 \ldots \ldots \ldots \ldots$ & 2 & 1 & 7 & 2 & 12 & 8.6 \\
\hline $1951 \ldots \ldots \ldots$ & 0 & 2 & 2 & 1 & 5 & 3.3 \\
\hline $1952 \ldots \ldots \ldots \ldots \ldots$ & 0 & 0 & 1 & 3 & 4 & 3.1 \\
\hline \multirow[t]{2}{*}{ Total............ } & 2 & 5 & 10 & 6 & 23 & 4.6 \\
\hline & \multicolumn{6}{|c|}{ (Removed for other experiments) } \\
\hline \multirow[t]{2}{*}{1953.} & $3(1)$ & $3(4)$ & $5(8)$ & $6(8)$ & 38 & 28.1 \\
\hline & \multicolumn{6}{|c|}{ (Kill-trapped) } \\
\hline To May, $1954 \ldots \ldots \ldots$ & $1(8)$ & (30) & $(47)$ & (57) & 143 & $100 ?$ \\
\hline
\end{tabular}

It makes little difference what time of day traps are set or examined as far as catching gophers is concerned. As a rule we set traps in the late afternoon and checked all of them in the early morning. When daytime temperature was not likely to reach 90 to $100^{\circ} \mathrm{F}$, we often reset in the morning and examined the traps again around noon, uncovering only those that the trigger indicated had been entered by an animal. During cool weather one trap set with care should thus catch two or three gophers in a 24-hour period. Traps undisturbed by gophers were usually moved once a day.

There is little gopher activity in the hot summer months from June through September on the nonirrigated, dry ranges. In fact, on the plot, most burrow systems opened at this time of year were not plugged by the gopher for several days, a week, or even longer. In this season we waited to set traps until after an animal had first plugged its exposed tunnel. For example, from the middle of July to the middle of October of one year, out of 410 holes opened, only 47 per cent were later plugged and only 35 per cent of the traps set at the plugged holes caught a gopher. Sometimes a day's trapping effort at this time might produce only one or two animals 
even if 20 or 30 traps had been set. Traps could not be left set during hot days, for the heat would kill the animals.

Trap mortality was not excessive. From May, 1949, through 1952, the period of the most intensive trapping, only 23 gophers, 4.6 per cent of the population (table 1), died in traps; hence, less than 1 per cent of the captures resulted in fatalities. Several drowned during wet weather. Even though the traps were insulated with a covering of soil, a few animals were left in the traps too long when the temperatures approached or exceeded $100^{\circ} \mathrm{F}$, and they became overheated and died. The maximum air temperature they could tolerate was not determined. An occasional animal dug under the trap and removed all the food, then died of "cold weather starvation" when it subsequently entered the trap. Several deaths were caused by bobcats or other predators dragging a trap containing a gopher into the open and spilling out the food during cold weather. We do not believe the trapping technique or the slight trap mortality materially affected the population density, for new individuals soon moved into vacated areas; to a small extent, however, it may have affected the population turnover.

\section{Marking and Recording}

Clipping off various combinations of toes proved successful in marking as individuals the live-trapped pocket gophers; it was accomplished with little apparent discomfort to the gophers and with little loss of blood. The three middle toes on the forefeet were not cut as they are important to gophers for digging and fighting.

The usual procedure for processing trapped animals was to bring them to a table in the field where they were weighed on a dietary scale (fig. 7). They usually sat docilely on the exposed scale pan without trying to jump off. We know of no other wild rodent so easy to handle. While they were on the scale, their molt pattern and weight were recorded on a $5 \times 8$-inch card on which had been mimeographed an outline of the surface area of a gopher. A new molt card was used each time an animal was handled. The molt data have been treated separately (Morejohn and Howard, 1956).

After being weighed, the gophers were picked up by their tails and put into a wire holding-sock (fig. 7) modified after Emlen's (1944) device for holding live wild rats. The animals were confined in the device by plugging the entrance with a rag so the operator could have both hands free. The gopher's feet were pulled between the wires for identification purposes and toe clipping. If it was a repeat capture, the individual's record, also on a $5 \times 8$-inch card, was then taken from the file. By checking the previous data on sex, trap site, date, and weight, errors in identification were kept to a minimum. The animal's number was then placed on the molt card completed earlier, and the weight data from the molt card were transferred to the individual record card. With both new individuals and recaptures the following types of additional data were always entered on the record card: young, sub-adult, or adult; sex; vagina open or closed; pubic symphysis open or closed; nipples small, medium or large ; lactation ; and testes abdominal or scrotal. 
After each batch of trapped gophers had been examined and records completed, the gophers were returned to the place of capture. Before they were released, however, the capture location that had been written on the trap was again carefully checked. Then the dirt that had been dug in order to set the trap was replaced.

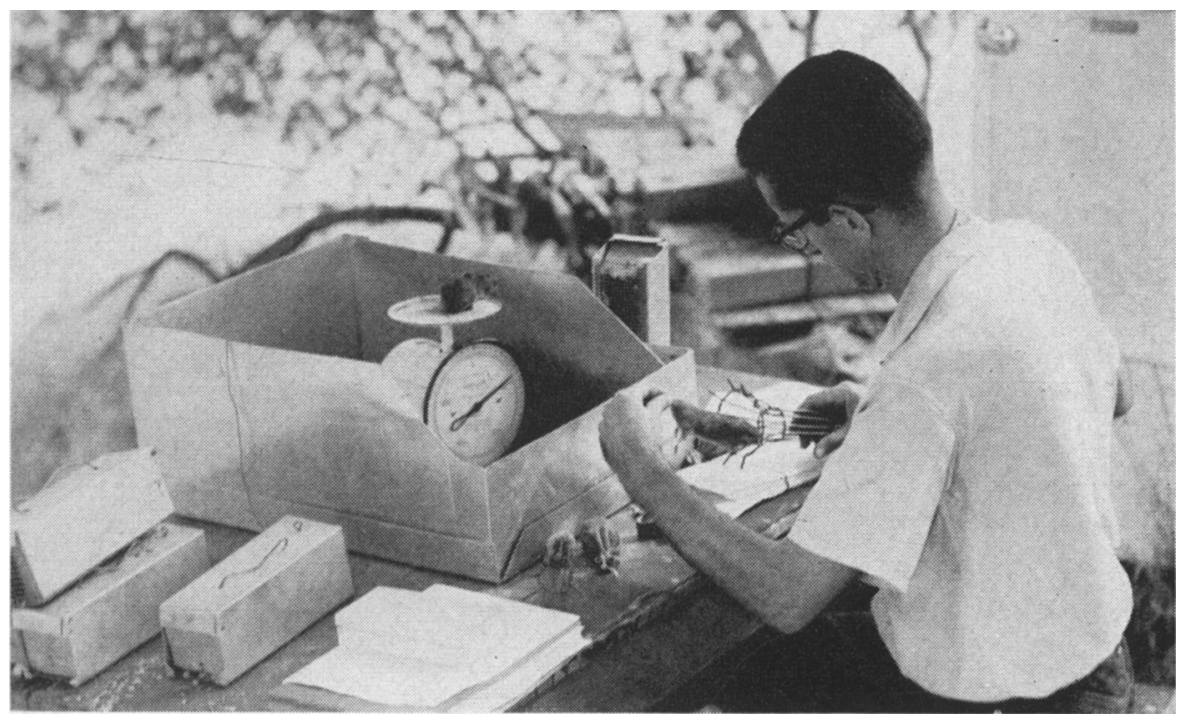

Fig. 7. Pocket gophers live-trapped on or adjacent to the study plot were examined at a table in the field, then promptly returned to their burrows, where captured.

\section{CAPTURE FREQUENCY}

The density of gophers of all ages known to be living on the plot ranged from 20.3 per acre in 1949 to 40.8 per acre in 1951 (figs. 8 and 9). A total of 330 pocket gophers were live-trapped on the plot 1,798 times, or an average of 5.4 captures per gopher. Of this number 141 individuals (722 eaptures) were males, 151 (1,025 captures) were females, and 38 (51 captures) were not sexed. Analysis by sex of the number of captures of individuals taken two or more times from December, 1948, to December, 1952, showed that 96 males had been caught $7.06 \pm 0.72$ times and 105 females $8.78 \pm 0.65$. Apparently both sexes are taken with equal ease, as there is no signficant difference in the average number of captures for males and females. Only individuals trapped two or more times are used in this analysis to avoid including dispersants and juveniles.

Few gophers showed trap shyness and adult individuals were readily trapped regardless of their age. Even though we attempted to reset traps far enough away to avoid recatching the same individuals on the following day, six females and four males were caught twice the same day and 86 individuals were retrapped 155 times on successive days of trapping. Fe- 


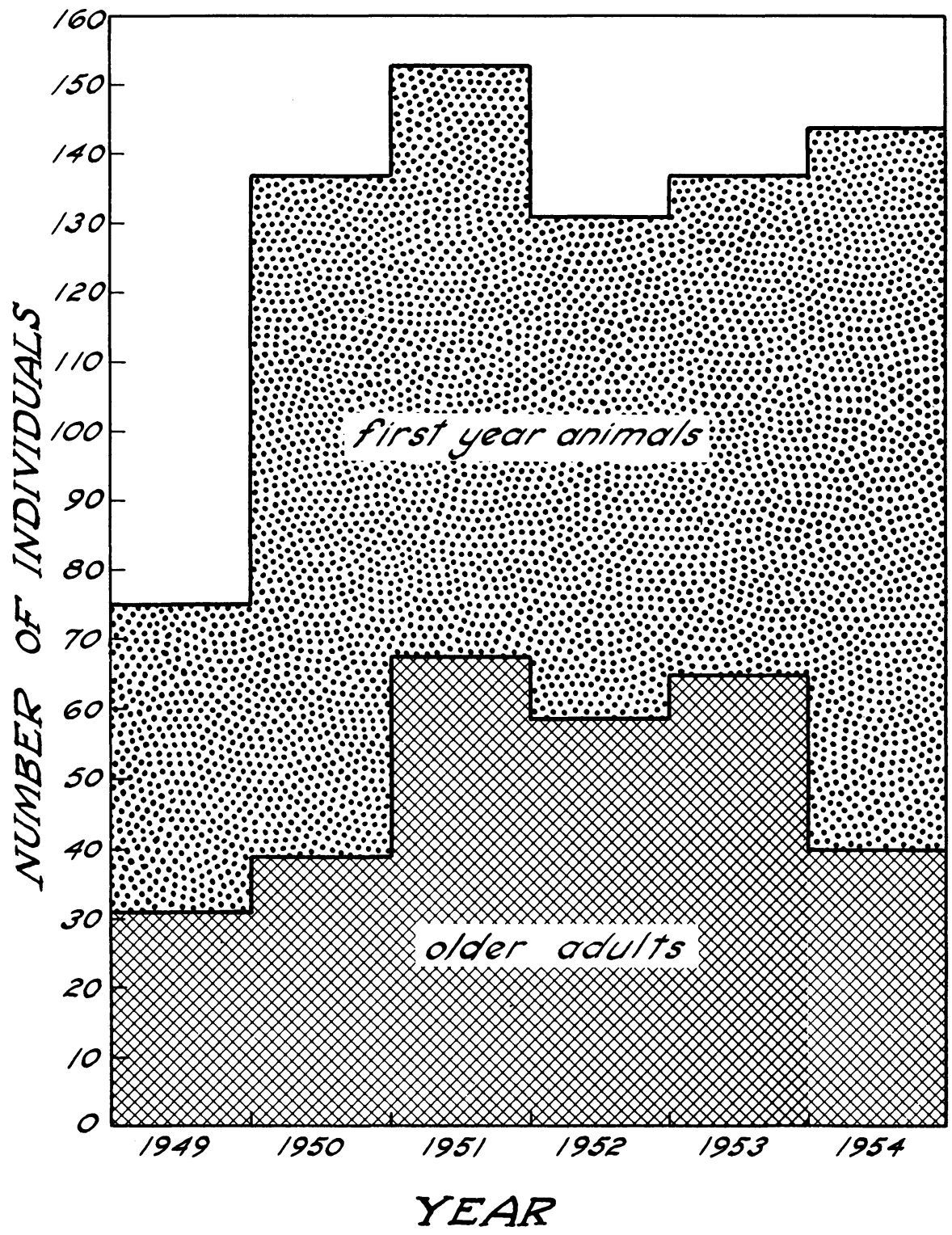

Fig. 8. The number of yearling ( 9 to 11 months old) and adult pocket gophers estimated as being present on study plot during each year from 1949 to 1954 , inclusive.

male 569 was trapped a second time two hours after the first capture. Females 248, 260, and 267 each gave birth to one or more young while in a trap. Practically all individuals were captured within a year of birth. It did not seem necessary to catch every gopher each month after the middle of 

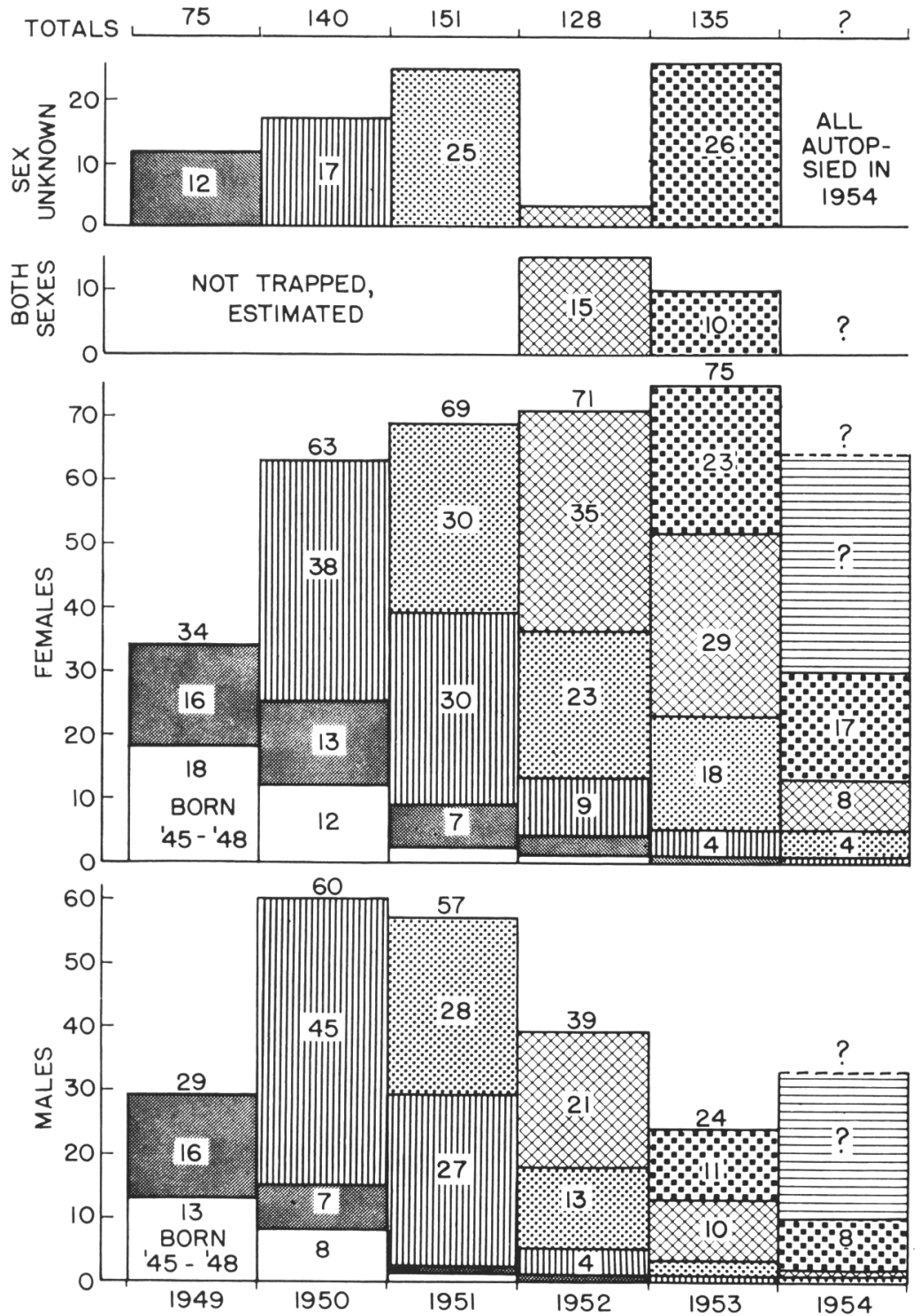

Fig. 9. Total number of pocket gophers inhabiting the plot during calendar years 1949 to 1954, inclusive, classified according to the year of birth and subsequent survival.

1951, so much less trapping was done thereafter (fig. 10). All but a very few adults were still captured more than once each year of the study, unless they lived along the edge of the plot, and no animal missed being retrapped at least once during each calendar year of its known life. 


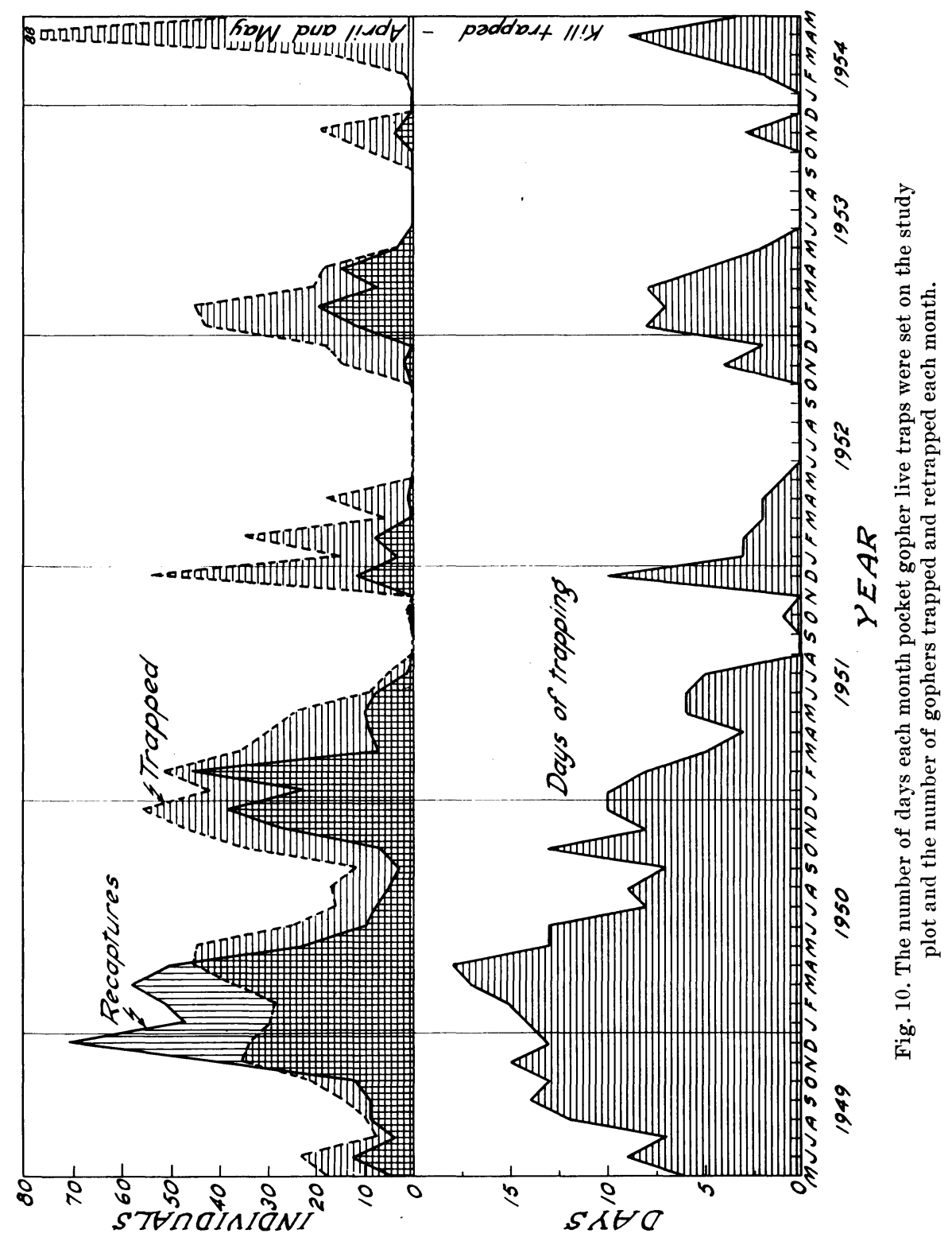




\section{AGE CRITERION}

To segregate the pocket gophers into different age groups, we have used the following definitions, which combine physiological maturity and calendar age. Immatures or juveniles are still under maternal care. Young adults or sub-adults have left home, usually have at least some gray (juvenile) pelage and have not bred; the females have a closed pubic symphysis. Sub-adult males that have lost all their gray pelage cannot be accurately distinguished

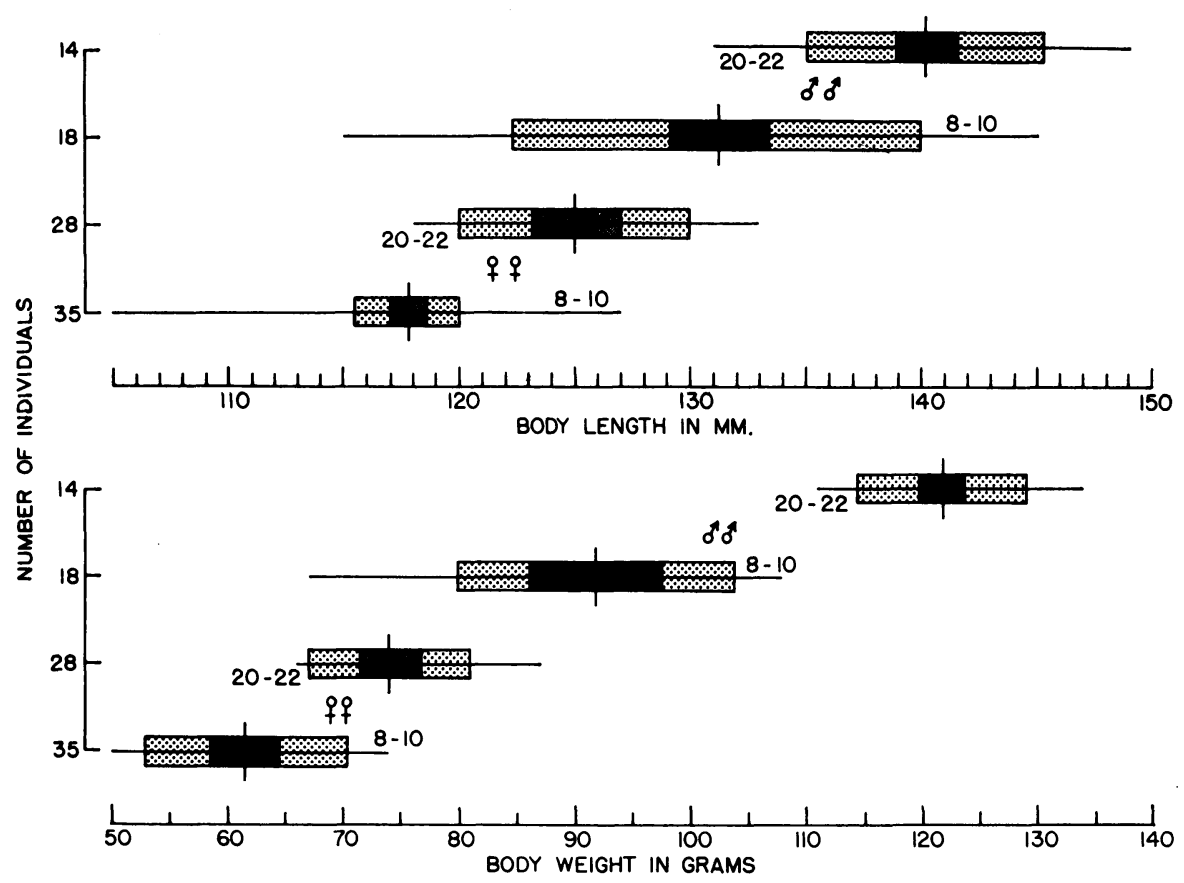

Fig. 11. A comparison between the age classes 8 to 10 months and 20 to 22 months for both sexes of pocket gophers with regard to their body length (upper) and body weight (lower). The perpendicular line is the mean, the solid portion is twice the standard error on each side of the mean (if they do not overlap, $t$ value is in excess of the 5 per cent limit), the spotted portion is the standard deviation, and the horizontal line, the extreme limits. (Method is after Dice and Leraas, 1936.)

from adults, although they seldom weigh as much as older males. Our data suggest that only a few females breed the same season they are born; but when this does occur, such an animal then becomes an adult when it is only three or four months old. Otherwise, adults were always at least 10 to 12 months of age.

To determine the sex of live pocket gophers that are not in breeding condition is sometimes difficult, particularly in gophers less than six months old. Many errors were made early in this study in sexing immature individuals, although they were corrected when the animals became older. In 
the analysis of the data all questionable cases are listed as sex unknown.

Body weight is better than body length for separating males between the age classes 8 to 10 months and 20 to 22 months, but body length is more diagnostic for females of these two age classes (fig. 11). All individuals used in this analysis were kill-trapped to keep weight loss while in traps to a minimum. No pregnant or lactating females are included. They were collected on or near the plot from November to January, inclusive.

With young animals there is little apparent external difference between sexes in the urogenital region. Merriam (1906) suggests that the external genitalia are hidden on gophers as an adaptation to prevent those parts from becoming injured during the animal's repeated travels backward through the tunnels. The scrotum is not recognizable on young males, and the mammary glands are not distinctive on the females until the animals approach sexual maturity. The extrusion of the penis, or the failure to do so, proved to be the best method of determining the sex of gophers that were under six to seven months of age.

The sex of older animals can be determined more easily. Mammary glands on females and the scrotal region of males are diagnostic even during the nonbreeding season. Males also begin to weigh more than females after they become a year old. Adult females can usually be easily recognized by palpating to determine whether or not the pubic symphysis is open. In the adult male gopher the pubic symphysis is normally well developed, whereas in the sexually mature female the two pubic bones are widely separated. Hisaw (1924 and 1925) has demonstrated the influence of the ovary on the permanent absorption of the pubic symphysis of pocket gophers. The absorption of the pubic symphysis in females is correlated with the general activity of the reproductive system preceding pregnancy and is usually complete before copulation.

\section{REPRODUCTION}

In males during the breeding season there is conspicuous enlargement of the testes and seminal vesicles, and sometimes the testes protrude into a scrotal-like sac. From observation of kill-trapped and live-trapped female pocket gophers, the vagina opens following follicular development. Whether ovulation is spontaneous or induced we do not know. Nipples enlarge during pregnancy, but with animals two years old or more, which have bred before, they may enlarge during follicular development.

A visible copulatory plug of coagulated semen often is present in the vagina. However, since it is soon lost, vaginas usually are open during pregnancy. In general, the appearance of the vagina seems to be the best external indication of breeding activity in the females even though it is not completely reliable. Except for one individual, the 89 kill-trapped female gophers having an open vagina also possessed one or a combination of the following conditions; nipples enlarged (85 per cent), lactating (30 per cent), developing follicles ( 17 per cent), corpora lutea (38 per cent), embryos (40 per cent), and embryonic scars (40 per cent). Of the 133 killtrapped animals that possessed a closed vagina, the following conditions 
were found: no indication of breeding (74 per cent), nipples enlarged (22 per cent), lactating ( 7 per cent), follicles ( 2 per cent), corpora lutea (4 per cent), embryos ( 8 per cent), and embryonic scars (14 per cent).

By November the genital tract of virgin females begins to enlarge, and in January and February many vaginas are open. Most young are born from the first of February to the middle of April (fig. 12). In this study, March 1 has been taken as the date of birth if no other information is available. We found no yearling or older females which did not breed. Sev-

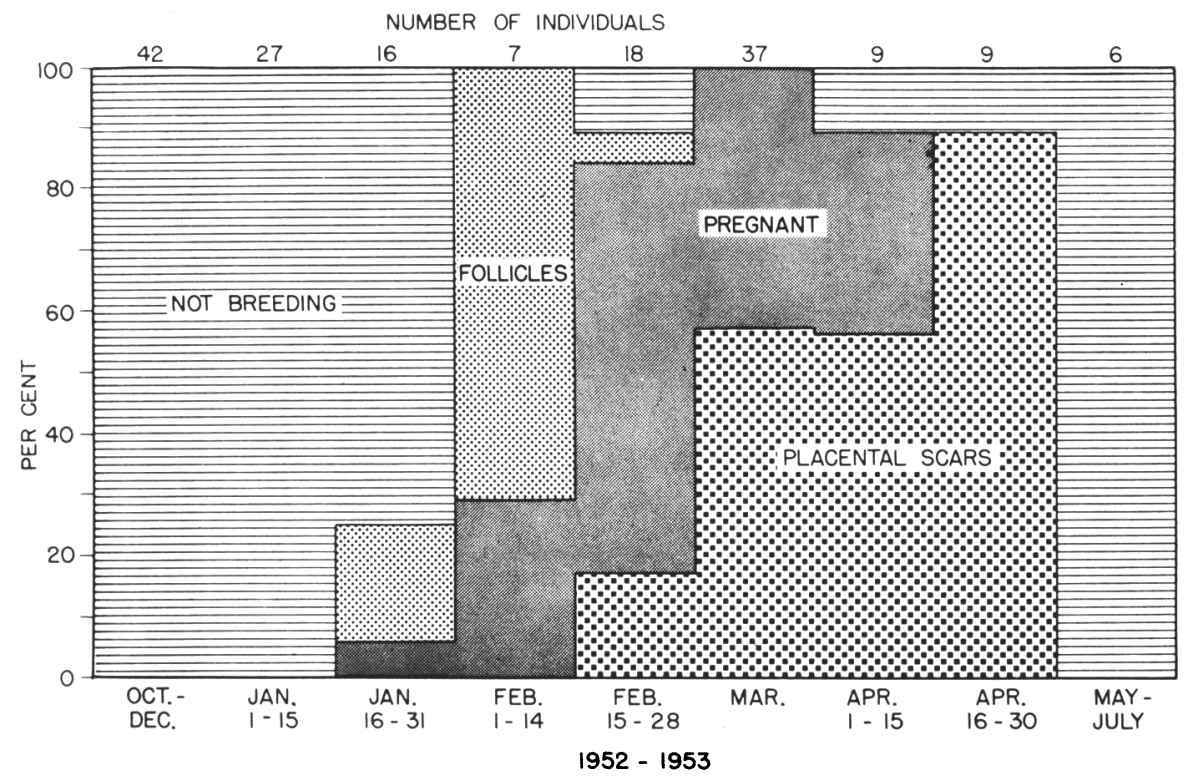

Fig. 12. Monthly status of breeding activity of 171 adult pocket gophers kill-trapped around study plot in 1952-1953. In March and early April three individuals listed under pregnant possessed corpora lutea but no embryos.

eral females born in January may have produced litters in April or early May of the same year, but they were not recaptured frequently enough to prove it conclusively. Females usually had only one litter a season, although occasionally their reproductive conditions indicated they had had two. Sex ratio is probably about equal at birth, but in older age classes there are more females (fig. 13).

The gestation period is estimated as about 30 days. No field-caught females gave birth to young after being held in captivity 30 or more days. The average litter size is 4.6 (fig. 14). In 1953 it was 4.69 and in 1954, 4.59, but these differences are not significant. Sagal (1942) found a litter of Thomomys bottae born in captivity to be weaned in about 35 to 37 days, and Wight (1930) estimates the weaning period for T. bulbivorus to be about one and one-half months. Drawings and photographs of the reproductive organs of T. talpoides are presented by Tryon (1947), and the repro- 
ductive cycles in $T$. bottae from irrigated alfalfa fields are discussed by Miller (1946). Gunther (1956) reports on the male reproductive system of T. bottae.

In the breeding season a male and a female and sometimes two females were occasionally caught in the same burrow on the same day. Sometimes we set two traps side by side, but most multiple catches of adults from the same burrow were obtained by holding a trapped animal for a short period

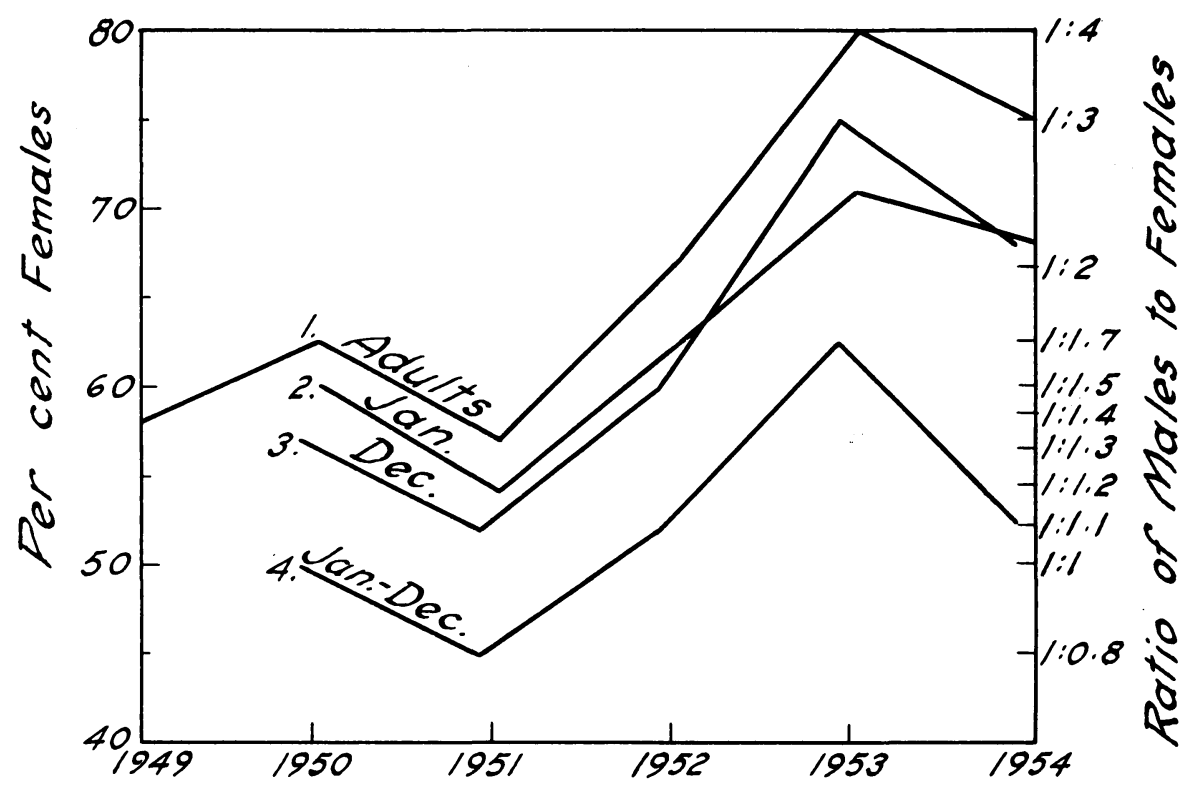

Fig. 13. The percentage of the pocket gophers on the study plot each year that were females (also ratio of males to females) are given for the following age classes: (1) the entire adult breeding population present in January; (2) breeding adults in January only 9 to 11 months of age; (3) sub-adults 8 to 10 months of age present in December; and (4) juveniles and sub-adults 1 to 10 months of age present at any time.

while another trap was set in the same hole. This practice was often followed when a second gopher had plugged the burrow behind a trapped animal or if the hole was plugged during the short time while a trapped individual had been removed for weighing and other examinations.

Our data indicate that mate selection is apparently determined anew with each breeding season; it seems to be governed primarily by what individuals happen to have adjacent territories that season. This is the same situation as found in deer mice (Peromyscus maniculatus bairdi), which pair anew each breeding season (Howard, 1949). Whenever a male gopher occupied the former territory of a smaller gopher, the adjacent female or females that year presumably mated with the new and larger male even though the apparent former mate was still living. The home range (territory) distribution indicates that one male would occasionally mate with three or four females living next to his territory. 
Since many of the old males were much larger than the females and probably too large to enter the smaller burrows of newly excavated systems made by females, it seems likely that the females in these situatious must. enter the burrows of males for mating. Most gophers live in systems partially excavated by other gophers formerly living in the area.

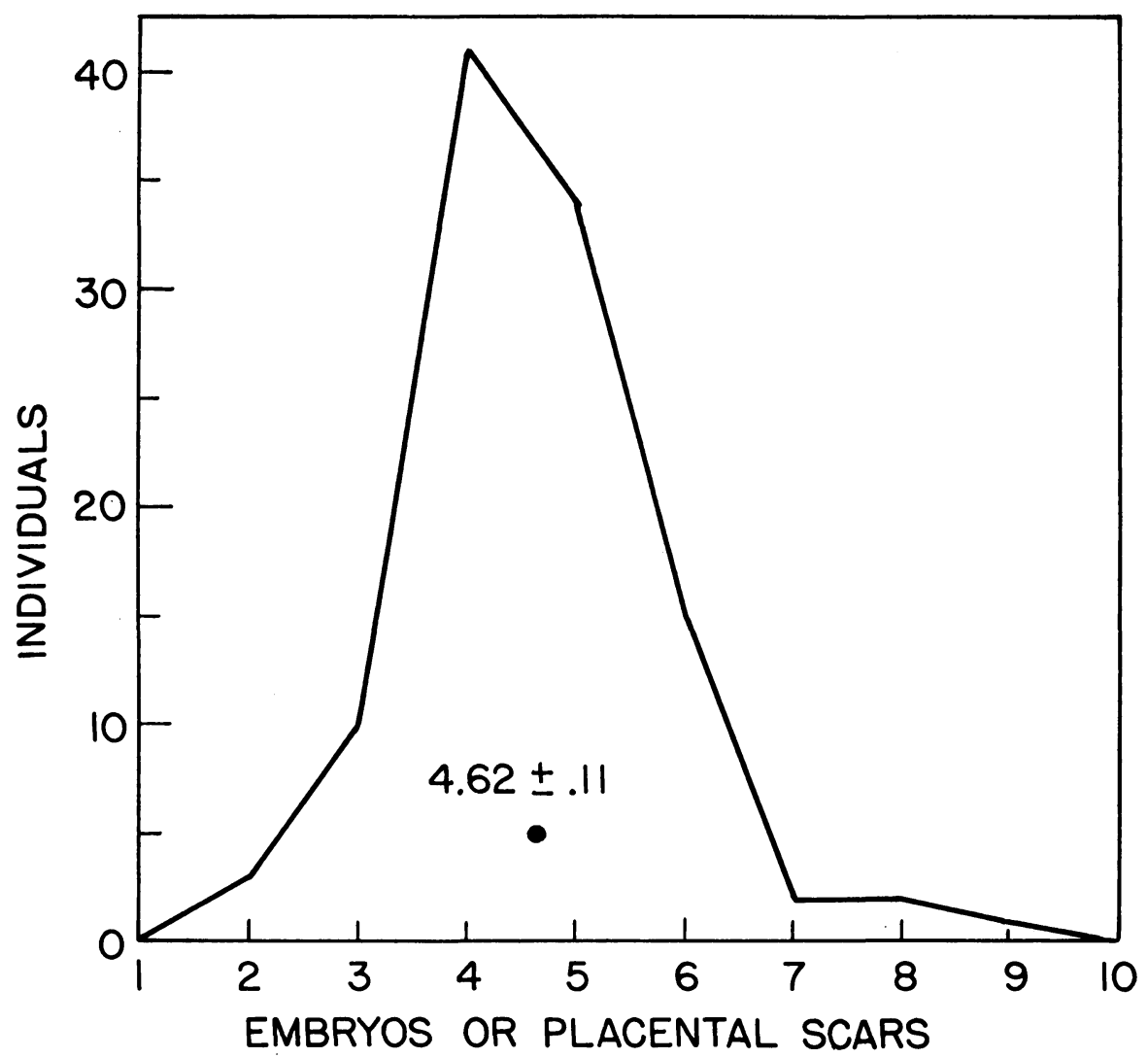

Fig. 14. The mean number of embryos of the kill-trapped pocket gophers around the study plot, and its standard error.

The gopher's intolerance of other gophers usually makes it impossible for two or more mature gophers to be successfully caged together, although English (1932) reports that he has been able to cage Geomys bursarius together. The heavier animal generally kills the lighter one regardless of sex. If the cage is large enough to permit one animal to avoid the aggressor, the smaller one then dies of starvation because the larger one hoards all the food. This occurred repeatedly in laboratory experiments, even in the largest cage, which was 7 by 12 feet. It was a glass-topped cage with several inches of soil, and partitioned with 2-by-4-inch boards to form a continuous strip of dirt about 70 feet long. When animals were placed at each end of 
this cage, there was no difficulty until their tunnels met. Then the larger one either killed the other animal or drove it from the burrow system.

Breeding has not been accomplished in the laboratory even though young females with swollen vulvas and open vaginas have been placed with males; the females were always killed by the males. Three young females were successfully caged together until they matured sexually, then they fought. Two of them managed to escape by jumping over the foot-high side of the opentop cage, although jumping over such a barrier is very unusual for gophers.

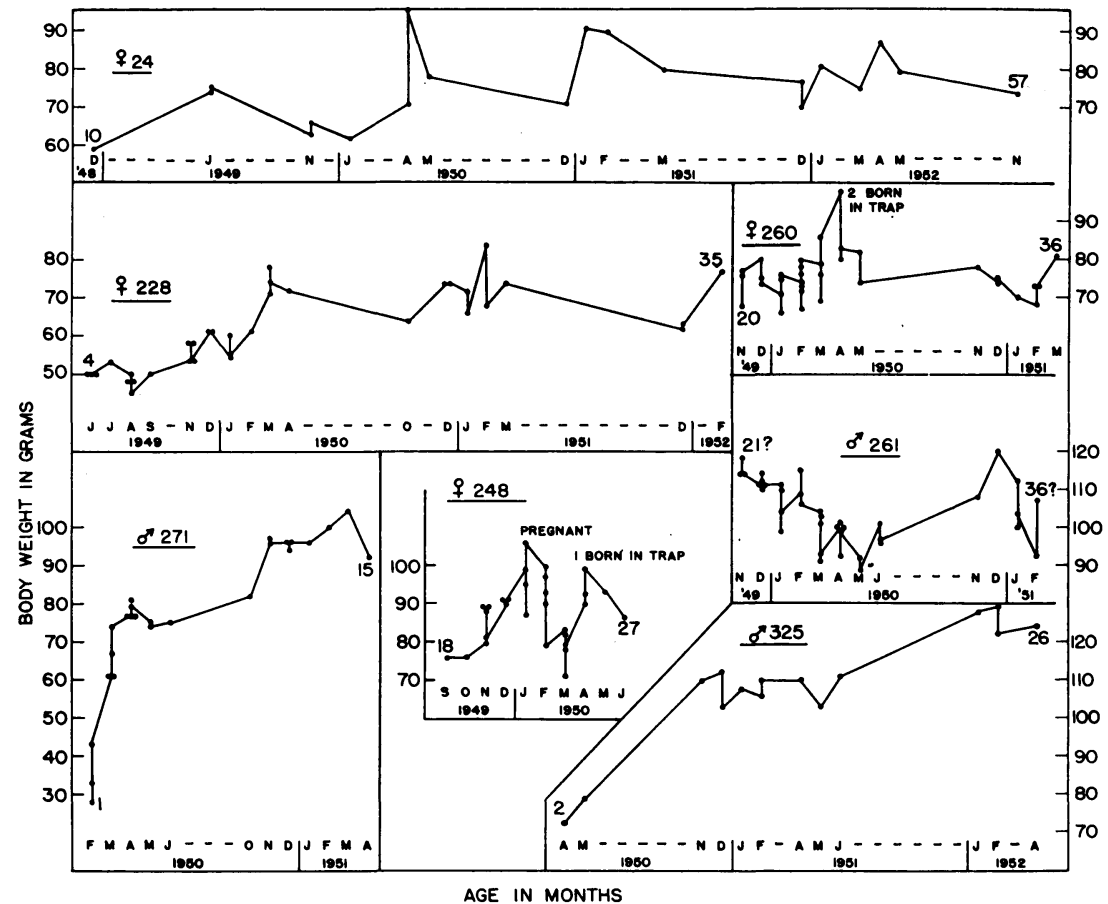

Fig. 15. Body weights of seven pocket gophers during the period they were live-trapped on study plot. Numbers at beginning and end of each curve indicate age of that animal in months. When more than one capture occurred during one month, the curve has been connected with the first and last capture weights for that month.

\section{BODY GROWTH AND WEIGHTS}

There is considerable seasonal variation in the weight of individual pocket gophers (fig. 15) and those of different age groups (fig. 11). Also, males more than females continue to grow after becoming adults (fig. 16), as has been reported by Tryon (1947), Miller (1952), and others. Even though males on the study plot added considerable weight with age and grew somewhat longer, weight alone was not reliable as a criterion of age or sex. Testes, however, are larger in two-year-old gophers than in one-year-olds (fig. 17). 


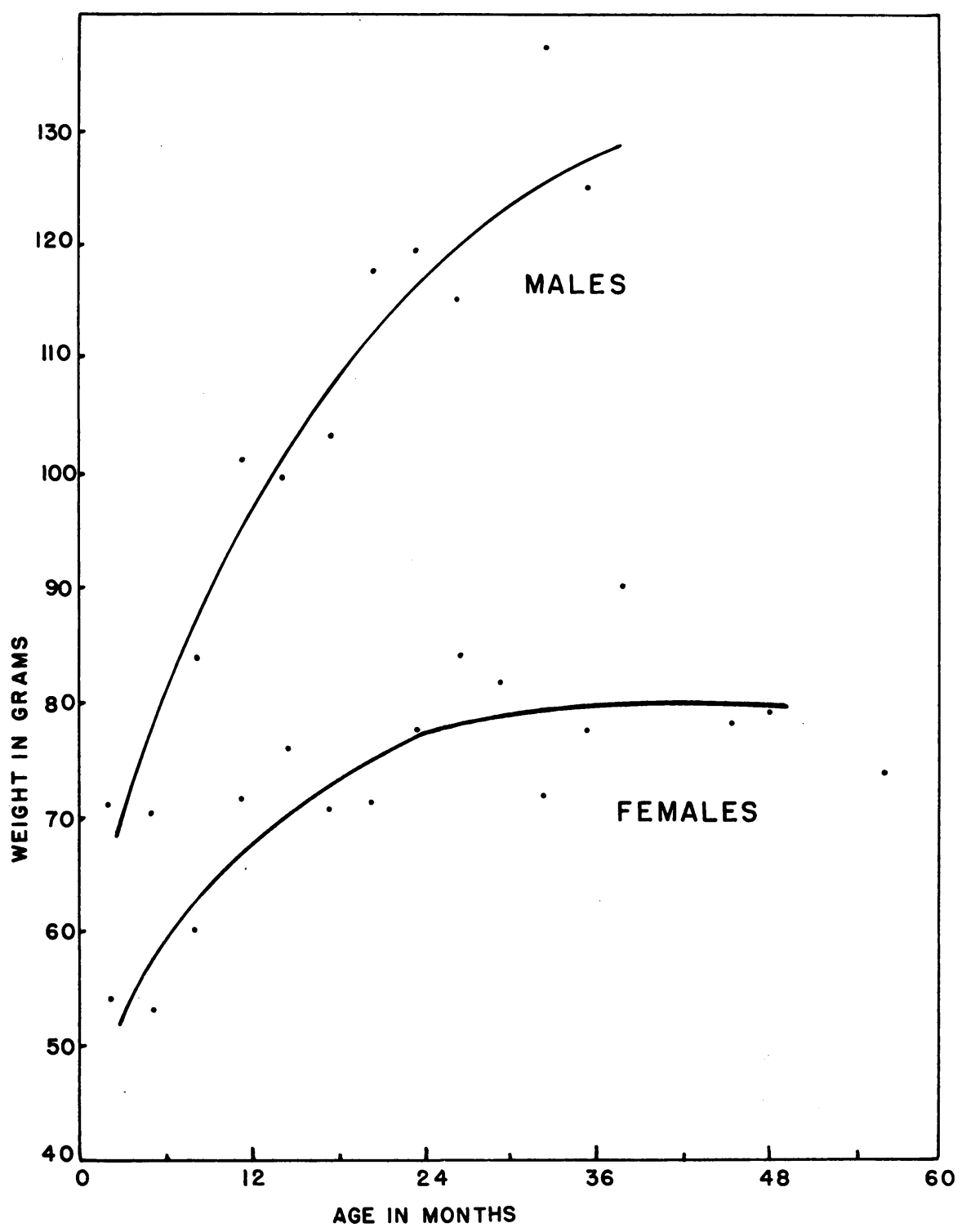

Fig. 16. Growth in weight with age of male and female pocket gophers live-trapped on study plot. The points represent the mean weights taken at three-month intervals from a total of 1,063 monthly gopher weights. Whenever an animal was captured more than once during the same month, the average of such weights is used.

A total of 1,063 monthly weights for both sexes live-trapped on the gopher plot were grouped by three-month periods to compare the seasonal and age-weight differences with both sexes (fig. 18). After reaching one year of age, males were half again as heavy as the females. When an indi- 


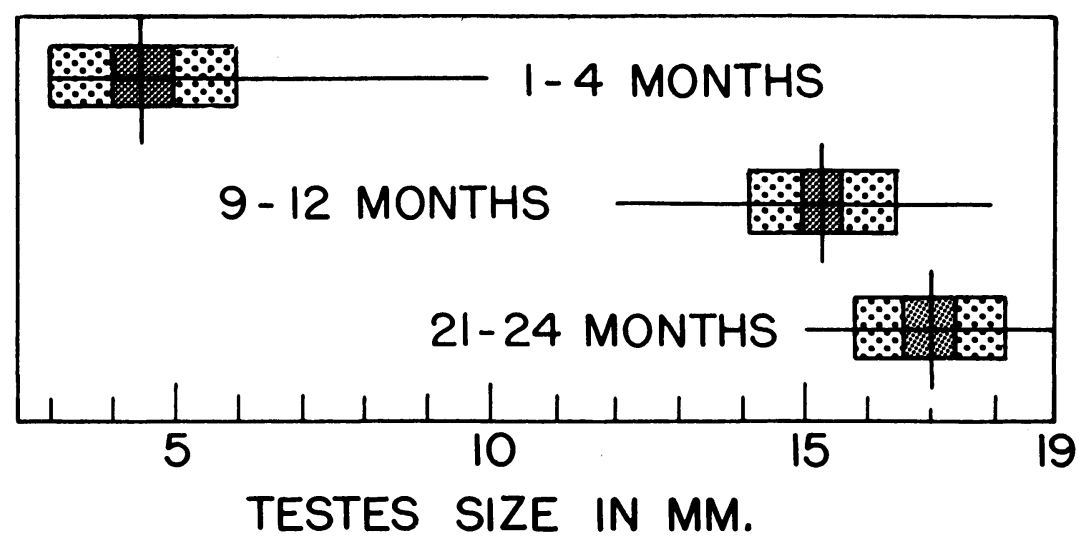

Fig. 17. Size of testes in three different age classes of kill-trapped pocket gophers. Thirty-one individuals comprised the 1 to 4 months age class, and 35 and 26, respectively, were used in calculating the other two age classes. The perpendicular line is the mean, the solid portion is twice the standard error on each side of the mean (if they do not overlap, $t$ value is in excess of the 5 per cent limit), the spotted portion is the standard deviation, and the horizontal line represents the extreme limits.

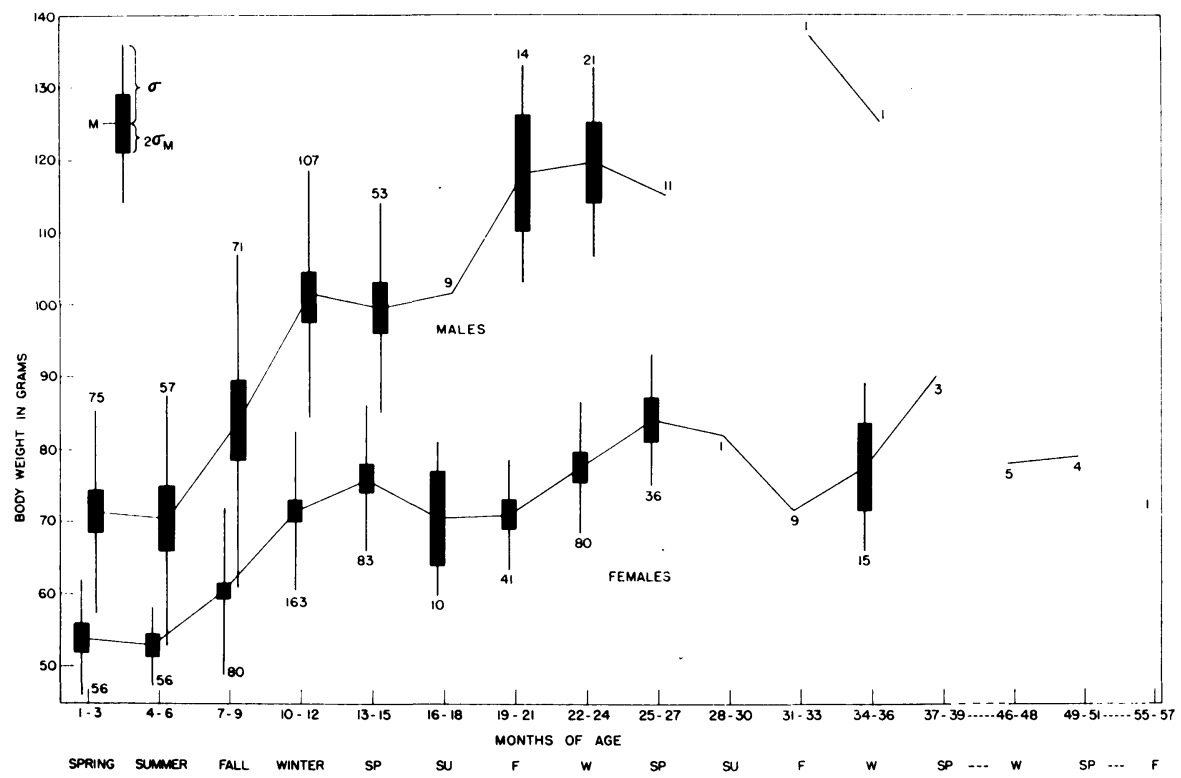

Fig. 18. Weight-age curves at three-month groupings for male and female pocket gophers live-trapped on the study plot. The numbers indicate how many monthly gopher-weight records were used. Vertical lines indicate one standard deviation each side of mean, not extreme limits. 
vidual was live-trapped more that once during the same month, the arithmetic mean weight was used, so that no gopher contributed more than one weight figure each month it was captured. This curve indicates the difficulty of ascribing any weight as the average for this gopher population or that weight alone can be used to indicate age.

Since some live-trapped pocket gophers lose considerable weight while confined in a trap even with plenty of food available, kill-trapping provides the most-reliable body-weight data. An attempt was made to learn how much

TABLE 2

CHANGE IN BODY WEIGHT OF GOPHERS CONFINED IN LIVE TRAPS AT PLACE OF CAPTURE

\begin{tabular}{|c|c|c|c|c|c|}
\hline \multirow{2}{*}{ Gopher number } & \multirow{2}{*}{$\begin{array}{c}\text { Initial } \\
\text { weight } \\
\text { (grams) }\end{array}$} & \multirow{2}{*}{$\begin{array}{c}\text { Time in trap } \\
\text { (hours: minutes) }\end{array}$} & \multicolumn{2}{|c|}{ Weight change } & \multirow{2}{*}{$\begin{array}{c}\text { Gram loss } \\
\text { per hour }\end{array}$} \\
\hline & & & Grams & Per cent & \\
\hline$\sigma^{7} 264 \ldots$ & 120 & $3: 50$ & +3 & 2.5 & +0.75 \\
\hline ๑ $393 \ldots$ & 76 & 17 & -10 & 13.1 & 0.59 \\
\hline \& 396 . & 92 & 7 & -8 & 8.7 & 1.14 \\
\hline$\sigma^{7} 400$. & 99 & $16: 15$ & -15 & 6.6 & 0.94 \\
\hline$\sigma^{7} 418$. & 108 & $24: 30$ & -9 & 8.3 & 0.37 \\
\hline$\sigma^{\pi} 436 \ldots$ & 84 & $17: 30$ & -10 & 11.9 & 0.57 \\
\hline \& 445. & 54 & $15: 45$ & -6 & 11.1 & 0.38 \\
\hline \& $446 \ldots$ & 65 & $15: 30$ & -6 & 9.2 & 0.39 \\
\hline Average. & 87 & $14: 40$ & -8 & 8.8 & 0.52 \\
\hline
\end{tabular}

weight gophers lost when confined in live traps containing surplus bait. Frequently, when we happened to hear a gopher caught while we were still setting traps, the animal was weighed immediately and then returned to the trap. Such individuals were weighed again when the rest of the traps were examined later that day or the next day. With eight animals handled in this manner (table 2), the change in weight ranged from +2.5 to -13.1 per cent of their initial body weight. The hourly change in weight ranged from +0.75 to -1.14 grams per hour $(-0.52$ average $)$ while in a trap. There was always plenty of rolled oats in traps.

The change in weight was also recorded for twelve additional live-trapped animals. They had already been in the traps for an unknown period of time, but after they were weighed they were put back in a trap, fed a surplus of rolled oats, and placed in a large barrel for four hours. During this interval the change in their weight ranged from +1.7 to -5.8 per cent of their first weight, with an average loss of 0.6 gram per hour. Another gopher, a female held by mistake in a trap for 20 hours, lost 22.5 per cent of her weight and survived to live another year. She had eaten all the food in the trap and was in a weakened condition. An example of how much weight can be lost without dying was shown by a male, on an inadequate diet, that lost 35.5 per cent of his weight in 17 days in the laboratory.

To get reliable comparative weight data of small rodents it is necessary to deduct the weight of the contents of stomach, caecum, and intestines. 
This can be done when kill-trapping, but it is impossible to adjust for this source of error in studies where animals are live-trapped and then released.

The combined weight of stomach, caecum, intestines and their contents of seven gophers ( $T . b$. navus) kill-trapped in an alfalfa field at Davis averaged 21.3 per cent (18.1 to 25.7) of the animal's gross body weight. The caecum plus contents averaged 8.6 per cent (6.9 to 10.3) of the gross body weight and 40.4 per cent (36.6 to 44.4 ) of the alimentary tract. Intestines and contents weighed nearly as much as the caecum. The stomach averaged 4.6 (3.5 to 5.8) per cent of the gross body weight and 21.8 (16.7 to 27.3) per cent of the alimentary tract. The combined stomach, caecum, and contents averaged 13.2 (10.4 to 16.1) per cent of gross body weight. Tevis (1955) found that the stomach and caecum plus contents of mantled squirrels (Citellus lateralis) averaged 13 per cent (3 to 29) of the gross body weight, and of chipmunks (Eutamias) 7 per cent (1 to 22) of the gross body weight.

There is considerable annual fluctuation in body weight. The greatest loss of weight of live-trapped gophers occurred in pregnant females. One female, for example, following parturition, lost 33 per cent of the weight maintained during pregnancy. This occurred between her first and second litter of that same year. Weights of both sexes, however, varied a great deal with different seasons. The maximum seasonal drop in weight of a male was 24 per cent, although most males lost much less than this.

\section{LONGEVITY}

Life tables for the pocket gophers on the study area were constructed after the method of Farner (1945) and others ; only individuals surviving to September 1 of the year of their birth were used. This meant that the gophers were then approximately six months old since most of them were born about March 1. This method eliminates the bias of juvenile mortality, but to obtain more nearly the real age, six months must be added. Survivorship curves using both actual and weighted mean mortality rates by the method proposed by Farner (op. cit.) were constructed (fig. 19, left) which clearly show that females live longer than males. Similar curves were also drawn using the percentage deviation from the mean length of life (fig. 19, right). By this latter means more accurate comparisons can be made between different samples or with other animals. For example, gophers have a percentage deviation from mean length of life that is quite similar to that of late fall-born prairie deer mice (Peromyscus maniculatus bairdi), using data from Howard (1949). But the situation is quite different when the gophers are compared with the deer mice that are born in the spring (some of these are also born in summer and early fall), hence breed in the season of birth, as compared with the deer mice that are born in late fall and, therefore, do not breed until the following spring (fig. 20).

Since most gophers are born about March and do not breed until the next year, we could not find a marked differential in mortality as occurred with the two seasonal populations of deer mice that matured sexually at different ages. Death rate is high during dispersal. Gophers, if they dispersed, did so when about two months of age. The fall-born mice did not disperse until 


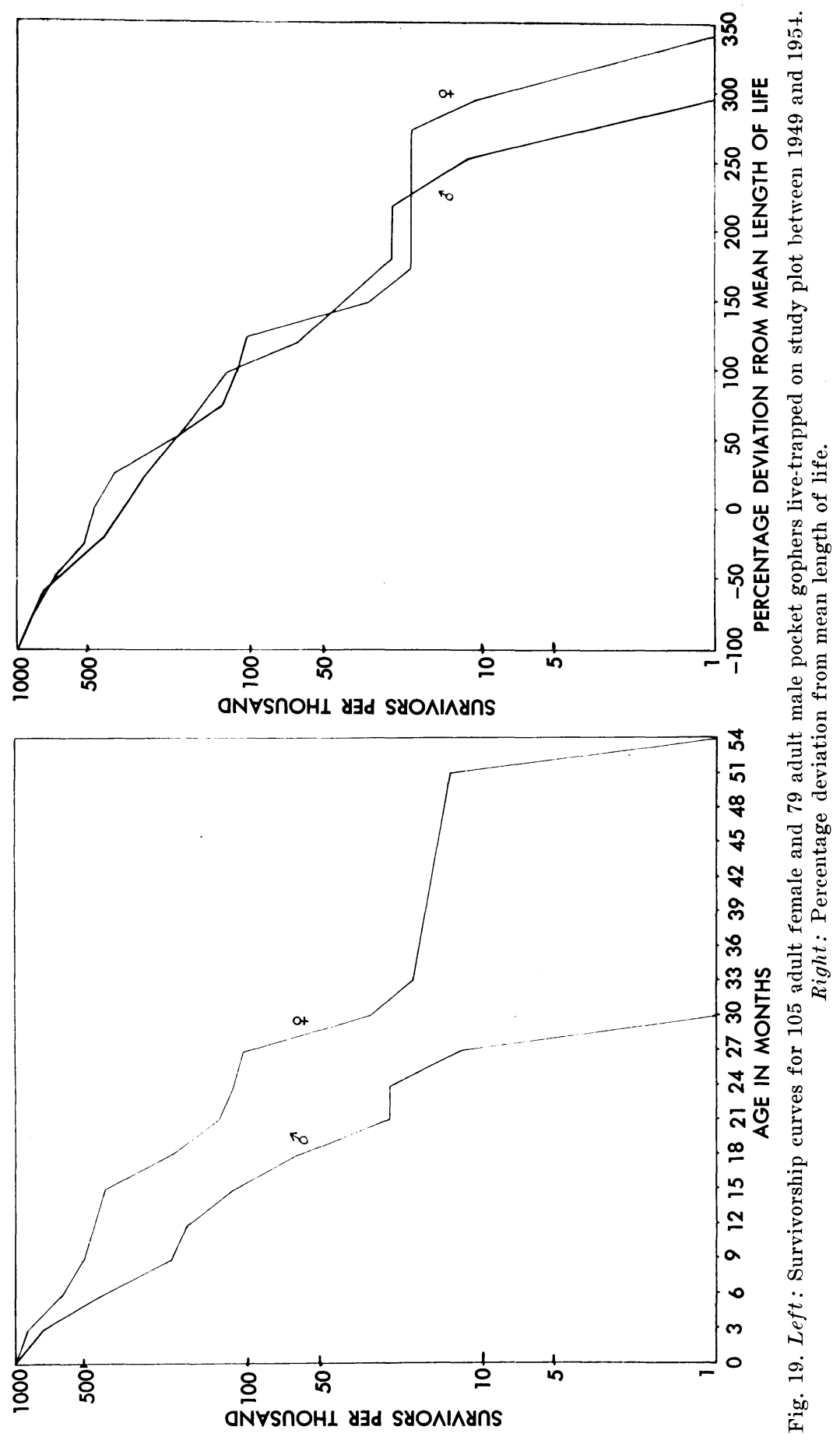




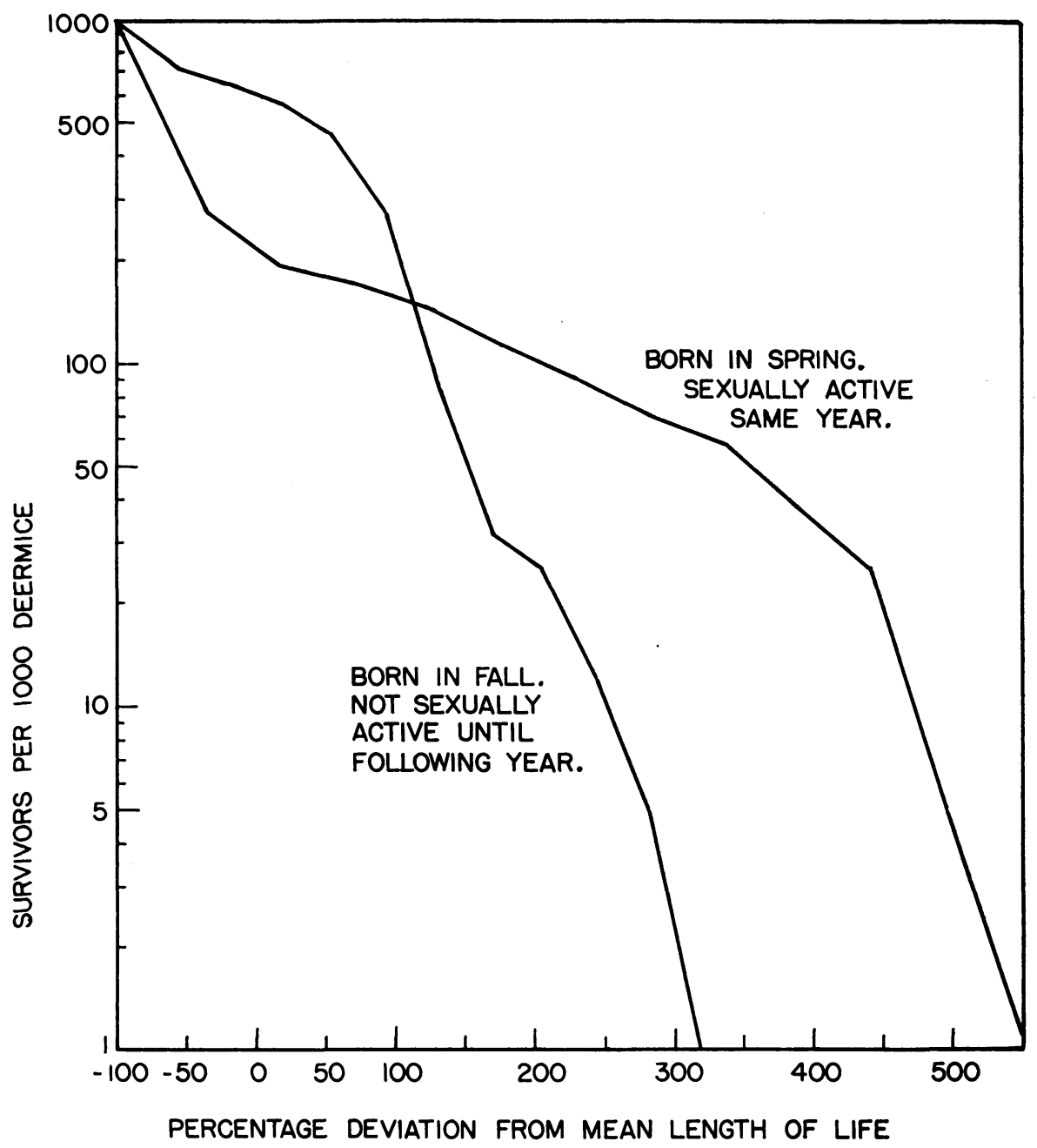

Fig. 20. The per cent deviation from the mean length of life for 152 prairie deermice (Peromyscus maniculatus bairdi) in Michigan. (Data from Howard, 1949.) 


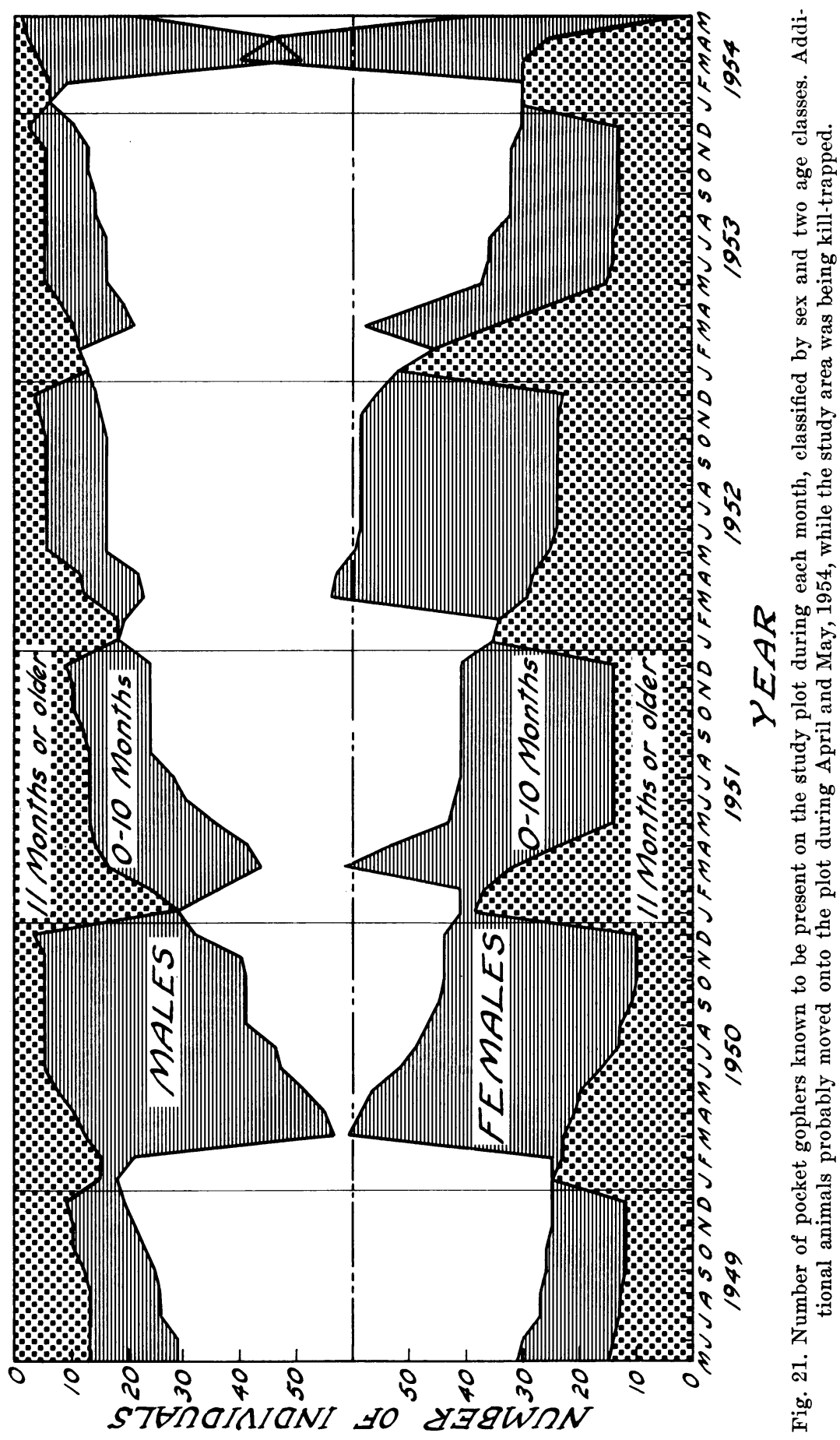




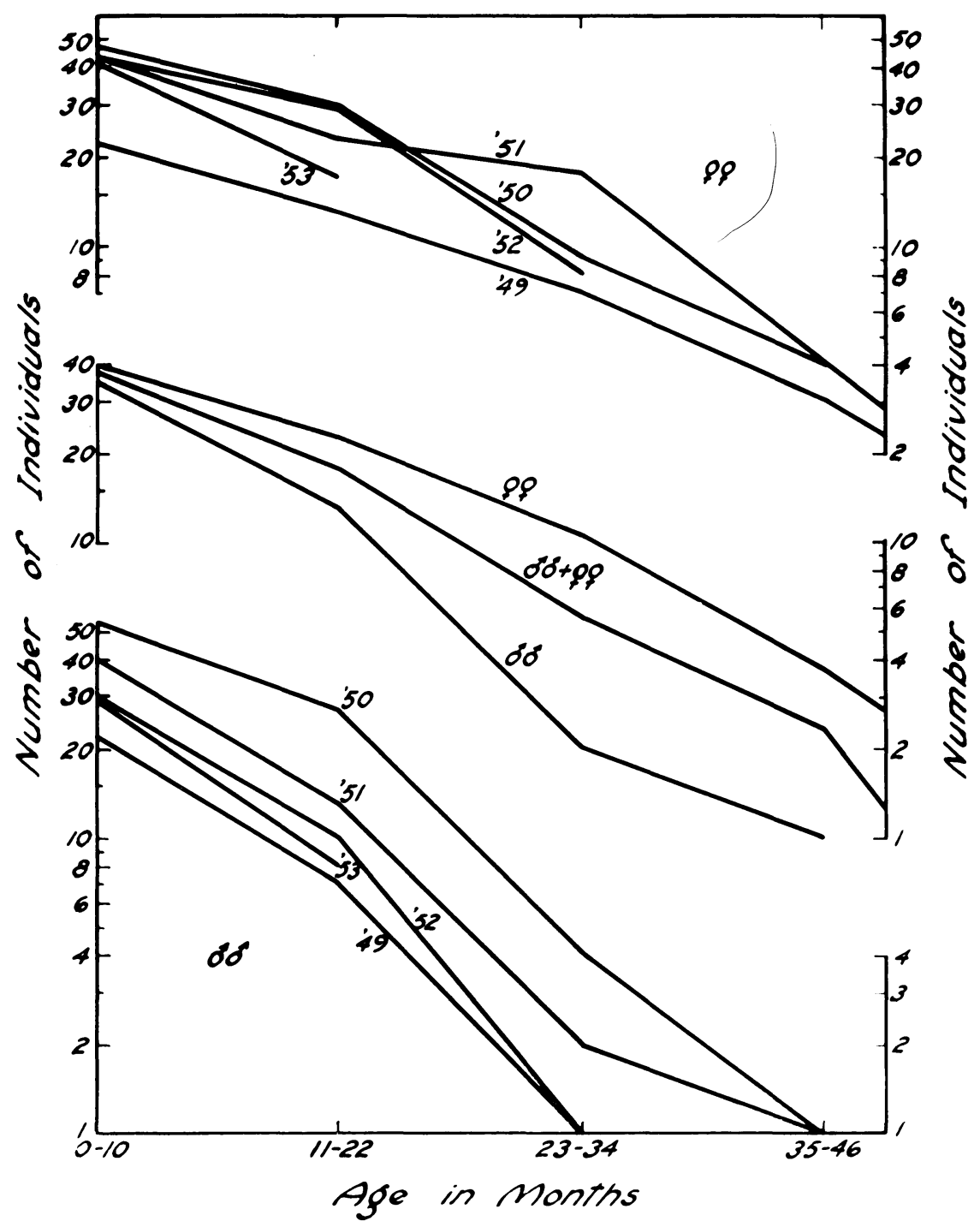

Fig. 22. Survivorship curves of pocket gophers on study plot drawn on semilogarithmic paper. The upper and lower group of curves indicate the survivorship for females and males, respectively, born on the years indicated. The center three curves are a composite of the others, the middle curve being the total of both sexes divided by two. 

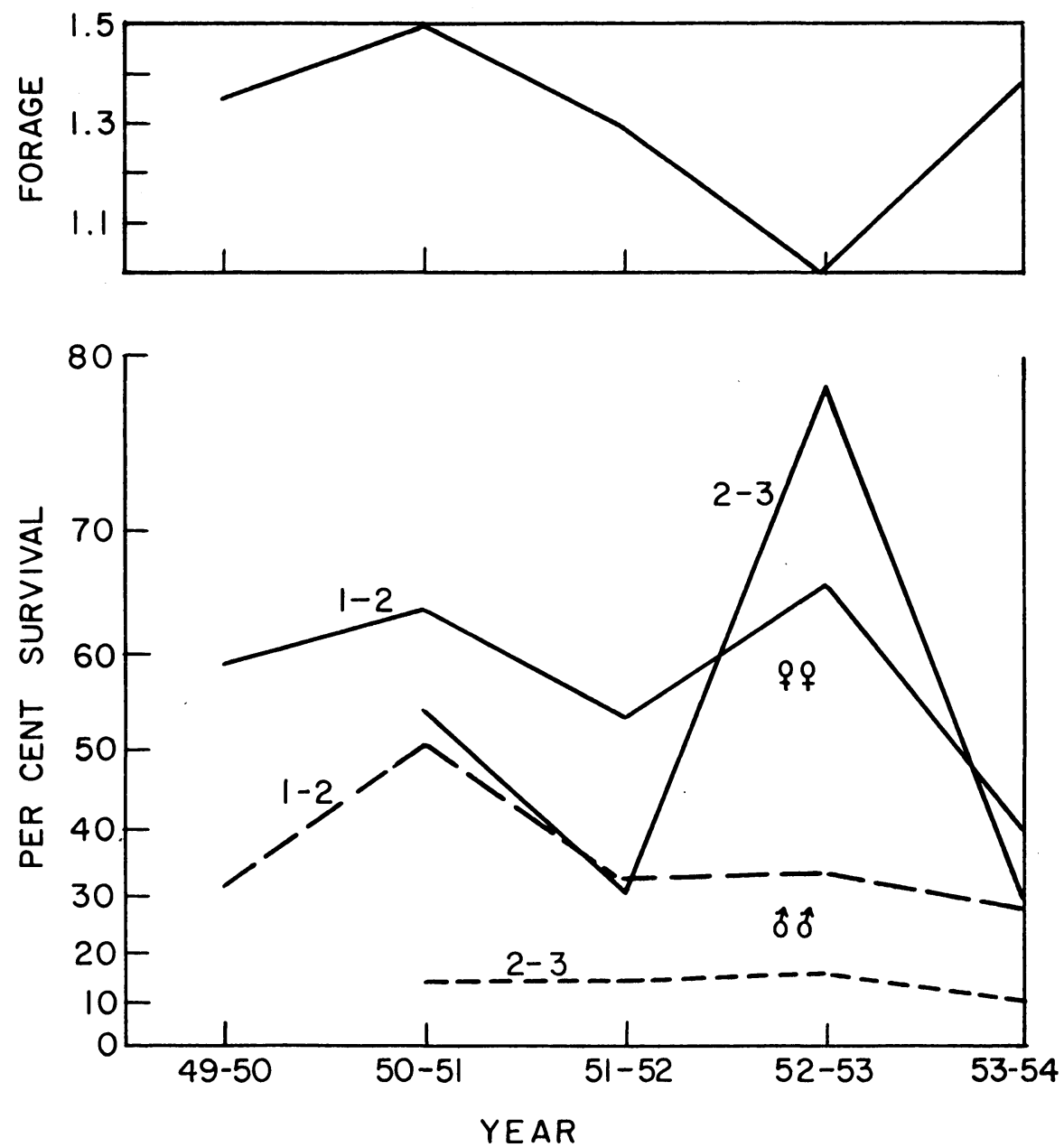

Fig. 23. Lower: A comparison of per cent survival (data from figure 22) of 1-to-2 and 2-to-3-year-old age classes for both sexes on different years, plotted on semilogarithmic paper. Upper: A comparison of the annual forage production with the 1953 yield at the San Joaquin Experimental Range. (Data courtesy Pacific Southwest Forest and Range Experiment Station, from Pastures $\mathrm{C}_{1}$ and $\mathrm{C}_{2}$.) 
spring, so that for the first six months of their lives, they had a higher rate of survival than did the other group which dispersed when they matured at 4.5 to 7 weeks of age. The population density of the gophers was highest in spring following breeding (fig. 21). In comparison with spring and summer months, the population of mice, on the other hand, was larger in winter, a time when the rate of mortality was also lowest.

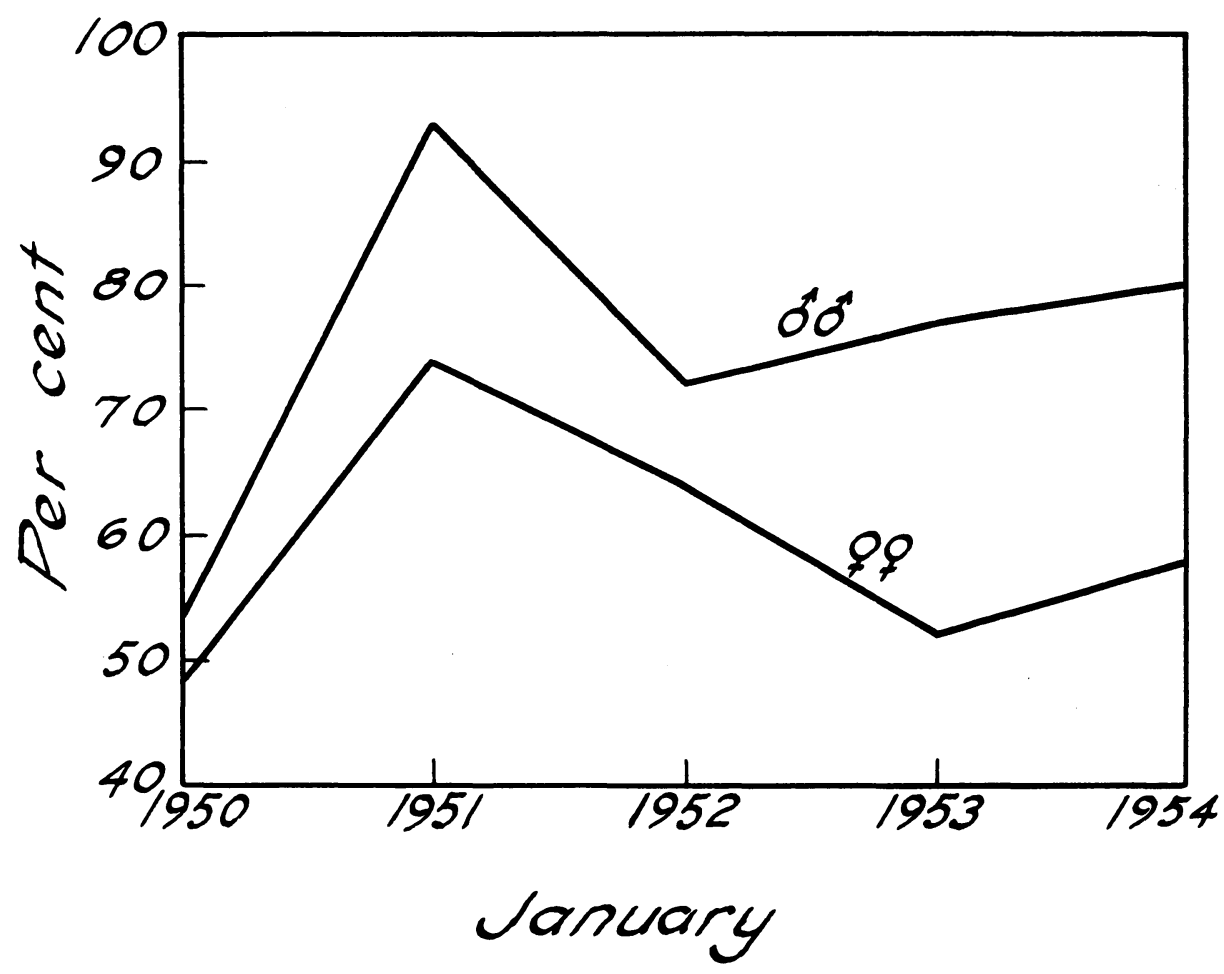

Fig. 24. Per cent of the breeding population of each sex, on January of each year, that was composed of yearlings (9 to 11 months).

The mean length of life for gophers taken after September 1 was about 7.6 months for males and about 12.3 months for females. It is, of course, necessary to add six months to these to obtain a figure more nearly approximating actual longevity. The oldest female on the plot lived to be at least four years and nine months of age, whereas the oldest male attained only three years.

Mortality, or survivorship, among all the gophers on the study plot was compared for different years of birth and by different age classes (fig. 22). The factors responsible for the irregular survival rates are probably complicated. For example, survival of females happened to be best in the year when the total herbaceous matter produced was the least of the five-year period concerned (fig. 23). Because of these annual differences in survival, there is a variation in age classes of pocket gophers on the plot from year 
to year (fig. 8). In 1950, a good forage year following poor winter survival (1948-1949), yearling gophers comprised only about half of the spring breeding population, whereas in 1951, following a good year, the yearling age class made up a much greater percentage of the population (fig. 24). A greater proportion of the males than females are yearlings because males do not live as long as females. Due to the good forage supply and low popu-

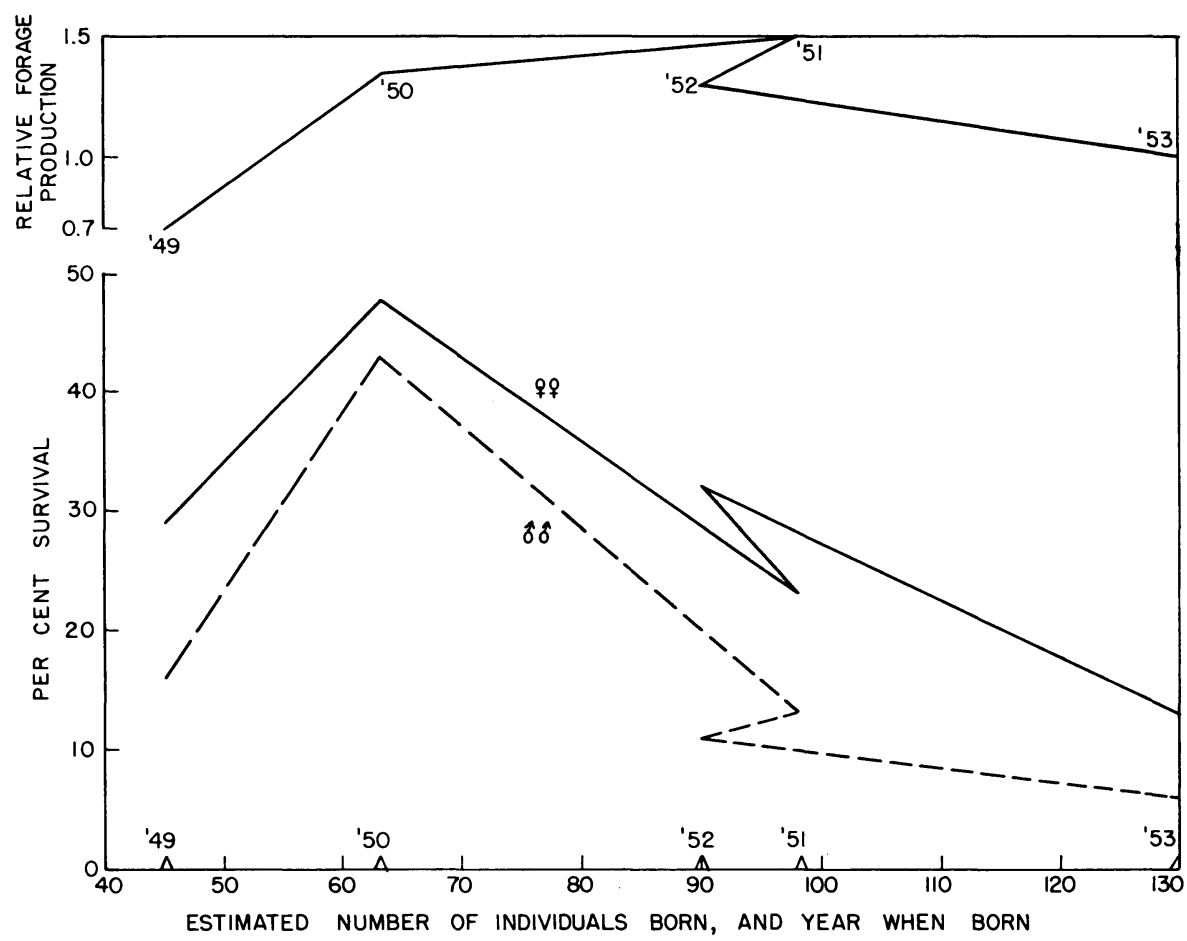

Fig. 25. Lower: Per cent survival of pocket gophers to at least one year of age for each sex in relation to both the year when born and the number of young of that sex presumed to have been born in each year. Upper: A comparison of the annual production of forage at the Experimental Range with the 1953 yield. (Data courtesy of Pacific Southwest Forest and Range Experiment Station, from Pastures $\mathrm{C}_{1}$ and $\mathrm{C}_{2}$.)

lation density in 1949, there was a high rate of survival of young in 1950 (fig. 25). There was also a marked sex difference in the survival of individuals born during a population high, when far more males than usual disappeared before becoming a year of age. After the population high of 1951, females regularly outlived males, although fewer female yearlings become two-year-olds if the population density is high, as in 1951 (fig. 26). Male survival appeared to be density-dependent, with the rate of mortality increasing as the population density increased, irrespective of food supply (fig. 23). Beginning in 1951, especially in 1952, and also in 1953, the rate or survival of male offspring to sub-adult or one year or more of age fell below that of females, presumably because of the increased population density (fig. 27). 


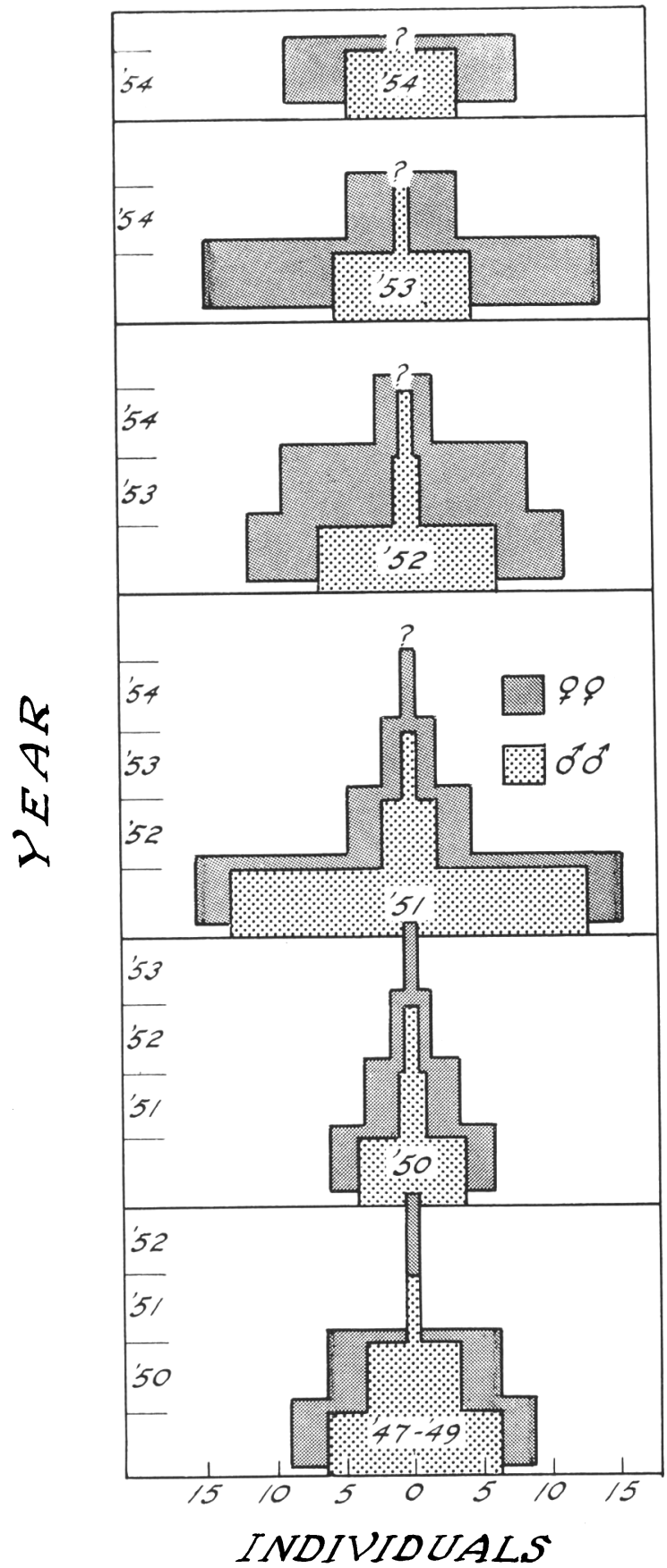

Fig. 26. The subsequent, annual survival of the yearling (9 to 11 months) gophers present on the study plot during January of each year is indicated: e.g., in the middle of the figure the base of the pyramid labeled ' 51 indicates the number of males and females 9 to 11 months of age that were present in January, 1951, and how many of these indivividuals were still alive in January of the years 1952 to 1954. 

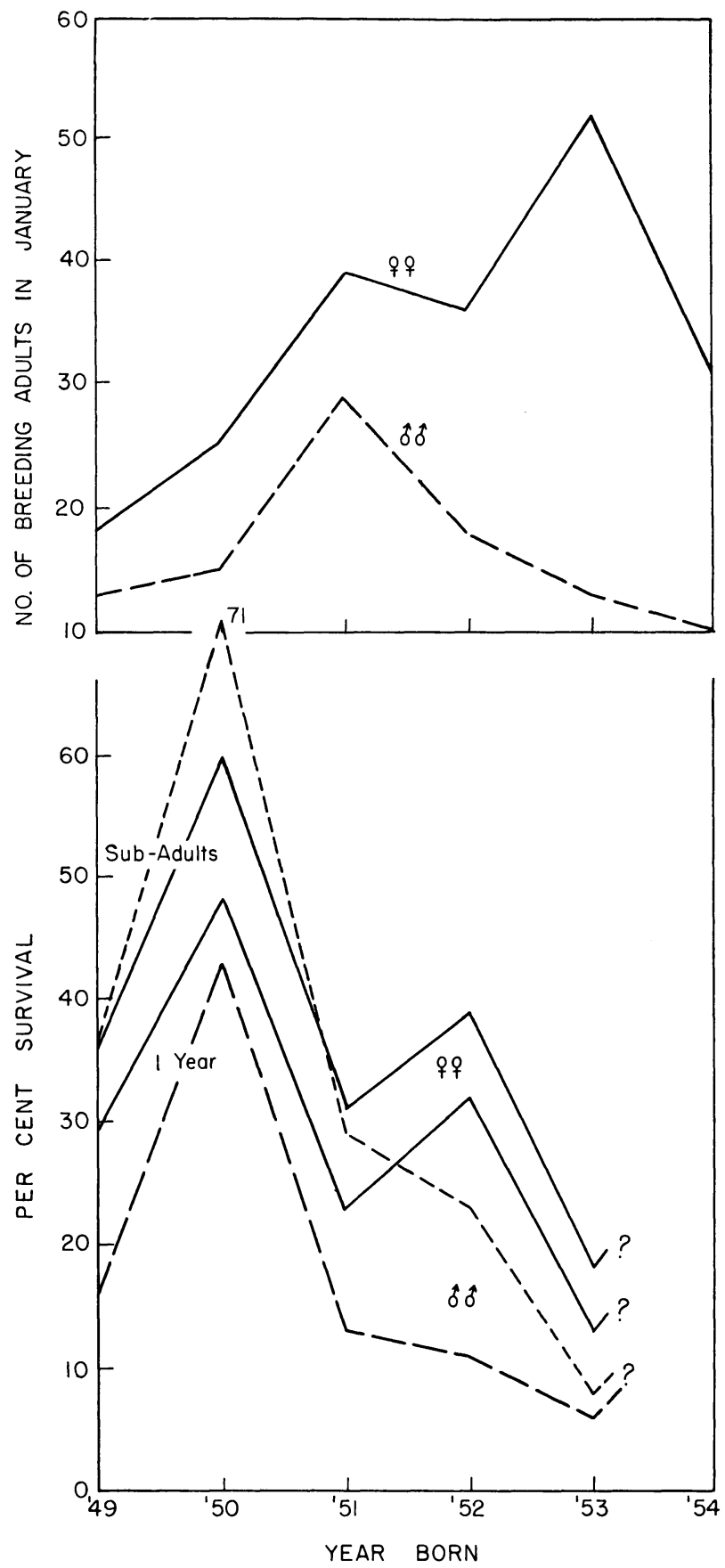

Fig. 27. Lower: A comparison of the per cent survival of all gophers estimated to have been born on the plot that lived and remained there long enough to reach sub-adult age, when they could then be live-trapped, with those that lived through at least one more breeding season to become one year of age or older. Upper: Number of breeding adults present in January of each year as an indication of population density. 


\section{DISPERSAL}

Since pocket gophers were seldom captured before they had been weaned, there was no way of knowing with certainty the area of their birthplace. Nevertheless, it was clearly evident that during March, April, and May many juveniles left home (to become sub-adults) by traveling, at least partly, along the ground surface. Scheffer (1954) and others have noted a spring and early summer dispersal of sub-adult gophers. Howell (1922) reports on surface wanderings of gophers, Bryant (1913) comments about the large number of young trapped in fresh road oil, and Imler (1945) caught gophers in the funnel traps he set for bullsnakes.

Our evidence for aboveground dispersal stems from the use of funnel traps essentially similar to Imler's (op. cit.). Seven of these funnel traps, each 6 feet long and about 2 feet wide and 1 foot high, were placed at intervals along two hardware-cloth drift fences having a total length of about 900 feet. These traps captured 197 gophers, all sub-adults, during four years (1949-1952). To verify these results, which were obtained about one-half mile from the plot, 238 feet of the drift fence and six funnel traps were moved to the study plot. During March, April, and May, 1953, 21 sub-adults were captured on the plot. Since these traps had been set so that three of them might capture gophers coming from one direction and the other three trap gophers on the other side of the fence, these six traps were equivalent to only three of those used in 1949-1952, each of which captured gophers from either side of the fence. A large number of sub-adults were captured in the funnel traps on the plot during 1954, but they are not included here since many of them were probably the indirect result of the capture station, homing, and trap-removal experiments being conducted at that time.

How far these prebreeding dispersers travel is not known. The plot was much too small to provide information about extensive movements. Fiftytwo individuals of dispersing age were captured on the plot. Since there was no way of knowing whether some of these had dispersed onto the plot before capture for the first time, it is impossible to tell what percentage of the individuals moved varying distances, as was learned with deer mice (Howard, 1949; Dice and Howard, 1951). Five moved between 100 and 200 feet; three between 200 and 300 feet; and six between 300 and 400 feet. Two of the latter group were recaptured off the plot. In all probability, gophers frequently disperse much greater distances.

\section{HOMING}

Even though pocket gophers appear to live a solitary existence, except during the breeding season, they seem to be acquainted with neighboring burrow systems. This was indicated by the results of tests conducted on the study plot to determine the ability of gophers to return to their home territory after being live-trapped and transported for varying distances (table 3 ). Twenty-three individuals were released 33 times at various release stations. 


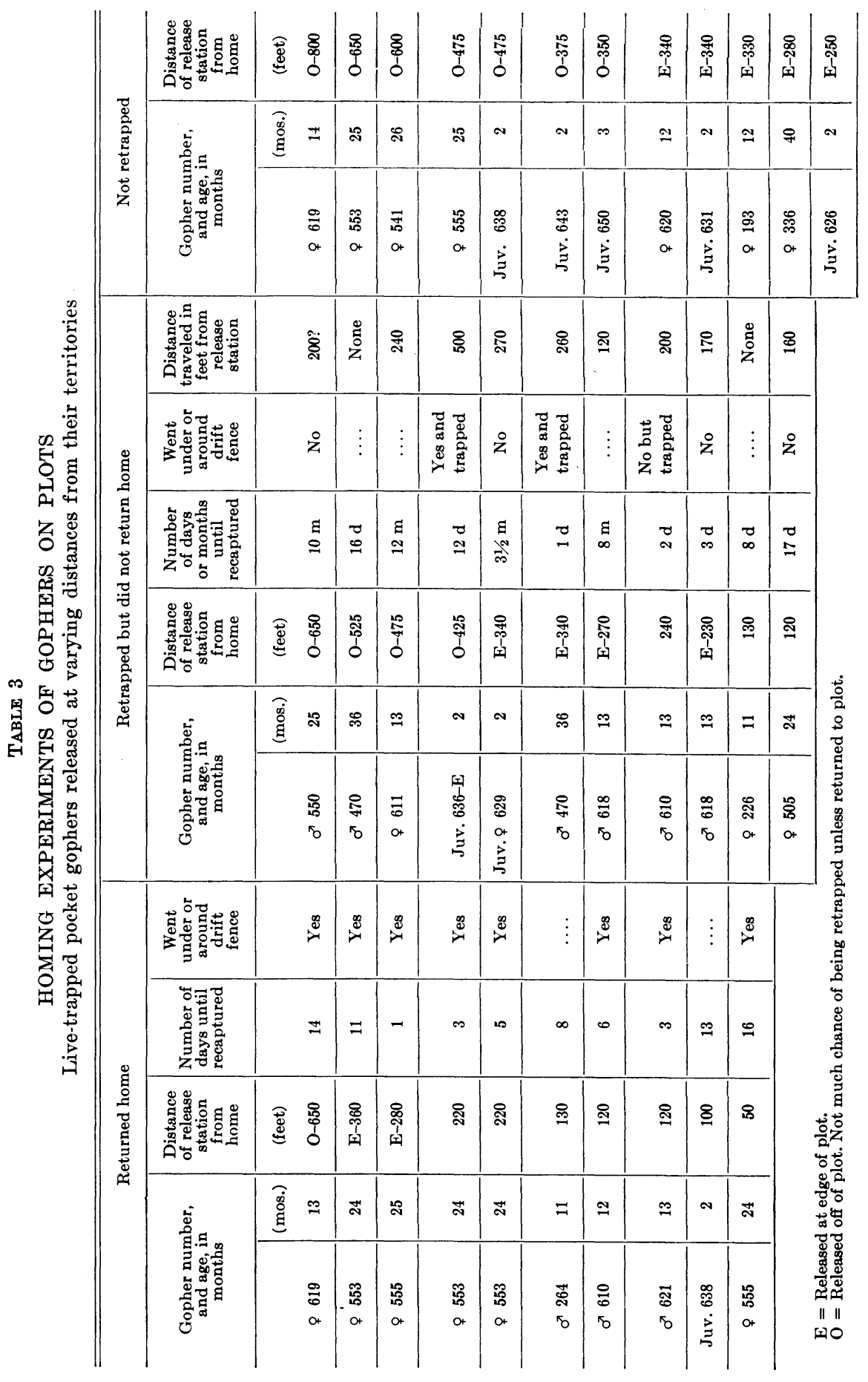




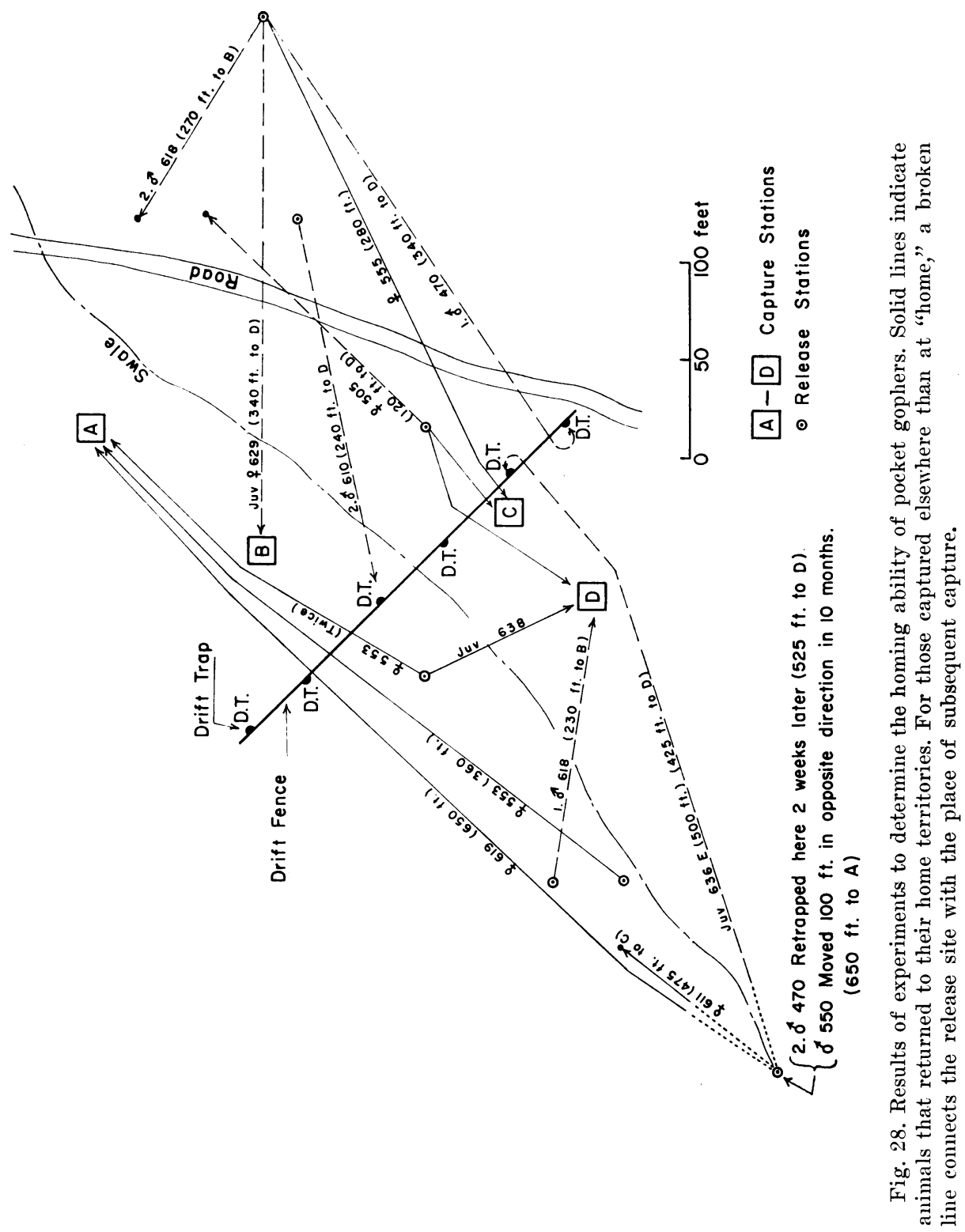


To find out whether released gophers returned home through underground passages or traveled across the ground surface, a drift fence of $1 / 3$-inchmesh hardware eloth was established on the plot. Its location is shown in figure 4. It stood 18 inches tall with several inches buried. Six funnel traps, patterned after those used by Imler (1945), were placed along the fence to catch gophers and other animals that tried to pass through the area. The

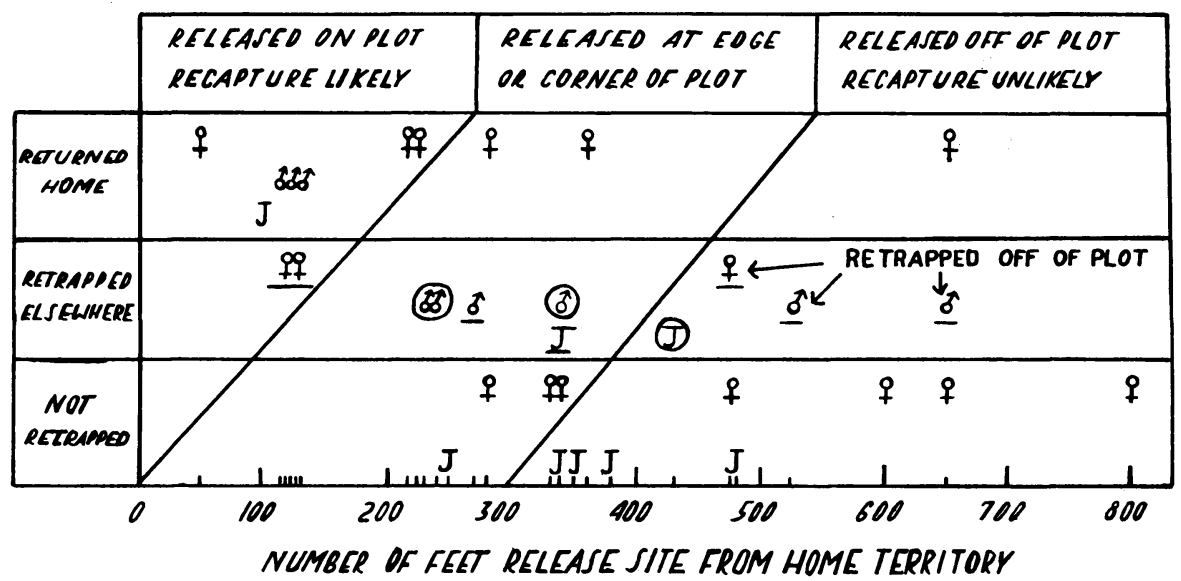

Fig. 29. Comparison of homing ability between female, male, and juvenile (sub-adult) pocket gophers released varying distances from their place of capture. Those underlined did not return home but established a new territory. Those circled were recaptured, shortly after being released, either in a drift trap or at a capture station, hence did not have a chance to return home.

fence and traps had already been used successfully elsewhere on the Experimental Range for five years to catch dispersing pocket gophers and other small vertebrates.

In our experiments to see if released gophers would be caught in drift traps as they returned home, only one animal was eaught in a drift trap that was located on the same side of the drift fence as the animal's release station. Two were captured in drift traps located on the opposite side of the fence from where they were released. Eight presumably went under the fence and returned home before being recaptured. This material is listed in table 3 and partly illustrated in figure 28. In nine instances gophers apparently were in burrows when they went past the drift fence. The gophers which went under the fence did not dig passageways, as no fresh workings could be found. They must have utilized existing burrow systems. Of the three released gophers that were later captured, in a drift trap, two of them had reached the opposite side of the fence before they were caught.

Both sexes readily homed when release distances were not too great (fig. 29). Of five females, three males, and one juvenile (sub-adult) released less than 230 feet from their home territory, all survived, and all but two of the females returned home. Of a total of nine male gophers released, all 
were eventually retrapped, but only nine of the total of sixteen females released were recaptured. Only two of the seven juveniles (sub-adults) released were recaptured, as might be expected since the capture stations where they were trapped may not have been their permanent home territory.

Much additional study is needed to supplement our limited data on the ability of gophers to return to their own territories when released beyond the territories of several others. How do they find their way through burrows of other gophers without getting into lethal fights? Are some tunnels more or less common property? Does it usually take hours or days to return? Our study furnished little information about the minimum time required to return home, so we do not know if some of the return trips were made within a few hours after being released.

\section{TERRITORIALITY}

Pocket gophers are territorial, that is, they appear actively to defend their home range from others of the same species. This defense is probably restricted to the tunnel systems, for gophers seldom venture aboveground more than a few inches from feed holes. Since caged gophers are fiercely intolerant of one another, regardless of sex, with the heaviest individual always dominant, we speculate that this same antisocial behavior exists in nature even though only a few of the animals trapped displayed combat injuries.

Only in the breeding season was more than one adult gopher trapped in the same burrow system. Then two females or a male and a female might be captured in the same burrow opening. Sometimes more than one animal could be trapped from the same burrow during the same day. Whether these multiple catches represent cohabitation or whether they are the result of rapid reinvasion after the first animal is captured is not known, but it does seem likely that in the breeding season there are occasional instances of individuals venturing at least a little way into their neighbor's burrow system when they are of the opposite sex or are both females.

Once a gopher has established a territory, it remains there for the rest of its life except for minor boundary shifts. These minor shifts may be of several types. Sometimes a large gopher crowds a smaller animal out of part of its former territory. On other occasions a gopher may shift part of its territory to take advantage of part of a recently vacated territory where better food and soil conditions are offered. But an established gopher seldom moves to an entirely new territory.

Rarely did we find overlap in territorial boundaries between members of the same sex (fig. 30). The few instances of apparent overlap in the illustrations are actually the result of minor boundary shifts during that time period and are also due to the method of determining territorial limits, which was done by drawing lines between outer points of capture. When the territories of males are superimposed on those of females, there are numerous examples of overlapping boundaries. Apparently members of opposite sexes have at least a limited penetration of tunnels across the outermost boundaries of the other's territory. For example, in 1949-1950 male 261 occupied an 
area that penetrated within the territory limits of females $22,24,26,205$, and 241. Generally the overlap occurs only at the periphery, but there were cases where the territory of a male completely enclosed that of the females, e.g., male 264 surrounded female 266 in 1950 and female 576 in 1951. Yet the orderly spacing of individuals in the population is still apparent.

An example of territorial behavior from 1949 to February, 1953, will be cited for one arbitrary gopher territory on the plot, which for convenience we will call area "A." A few additional comments on adjacent areas, particularly the one to the south of A, will also be given. The movements listed below by gophers into and out of area $\mathrm{A}$ are, for the most part, just minor shifts of portions of their home ranges.

From May to July, 1949, sub-adults male 225 and female 228 occupied area A. Male 225 was last seen December 7, but female 228 was trapped 12 times in A from August to December. Male 225 may have been driven out by male 231, for male 231 moved into a territory on the south edge of A sometime between August 9 and 24, after moving 115 feet to the east from his juvenile range, which currently was occupied by a larger male (195, trapped there only once and no female). It may not be significant but male 225 disappeared shortly after testes became scrotal in male 231 .

From January to April, 1950, female 228 was still present in area A. Male 231 moved into $\mathrm{A}$. He may have been driven out of the adjacent territory by male 199, who was larger and a year older and who moved into the adjacent territory on about January 31 . It is also possible that male 231 moved into A because of the females in and adjacent to A. Sometime in February male 231 had shifted to the north side of A, which was also at the south border of female 241's territory. In late February, male 231 moved east about 80 feet to just north of his original juvenile range and then disappeared after being seen there three more times, when he was then about 14 months old. The reasons for these moves by male 231 are not apparent unless he was pushed out by the females and male 199. On April 12, female 300 was trapped in the territory just south of area A.

From May to December female 228 was still in area A. She was trapped once a short distance in territory to the south of A but was retrapped one hour later 36 feet away, back in A. Juvenile female 365 was trapped four times in A from May to July and then disappeared. Male 199, who was in territory to the south, drowned in a trap in A during a heavy rain on November 14. Sub-adult male 357 was trapped in A and then died from overheating in a trap in the territory just south on July 27 . On November 7, male 195, then 20 months old and 345 feet from his juvenile range, was trapped once in territory just south of A but was never seen again.

During 1951 female 228 was still in area A and female 241 was still living in territory just north of A. Sub-adult female 515 moved into the west side of A in May and remained there. Between April and June sub-adult males 454,470 , and 518 were trapped at least once in A, but male 454 and male 518 were never trapped again. In the territory south of $\mathrm{A}$, female 300 was last trapped in April and no other females, were in the area, but just prior to 


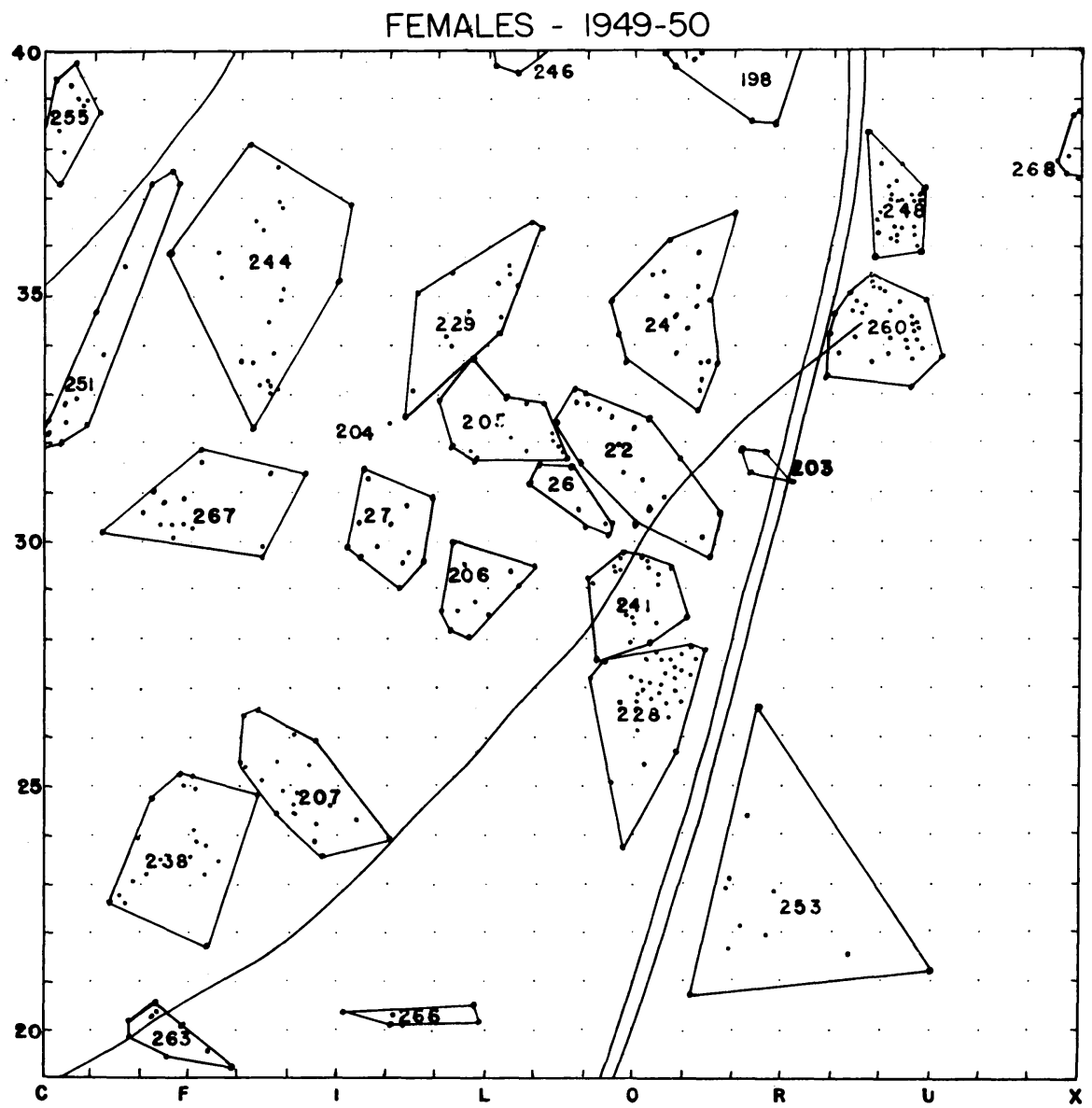

Fig. 30A-H. The relative size of territories of male and female pocket gophers on study plot as determined by connecting, for the most part, the outer points of capture. The coordinates are staked at 20 -foot intervals (ordinates numbered from 19 to 40 , abscissas lettered from $\mathrm{C}$ to $\mathrm{X}$ ). To insure that these individuals represent the stable population, no gopher is included unless it was trapped two or more times between the period from November 1 through February. Where territories appear to overlap, it is due to individuals occupying such areas at different times.

Fig. 30A. Female pocket gopher territories for 1949-50. 


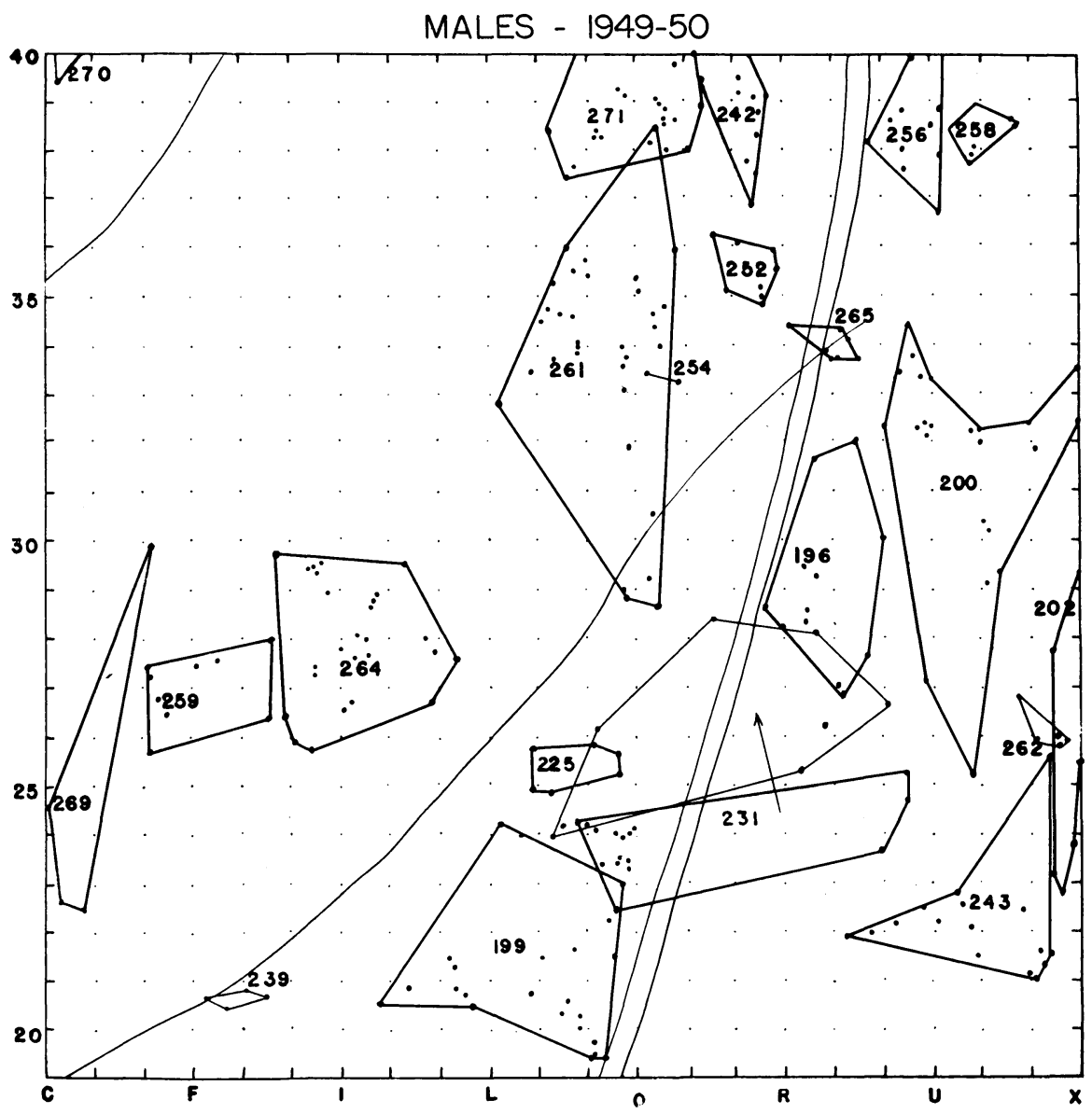

Fig. 30B. Male pocket gopher territories for 1949-50. 
FEMALES - 1950-51

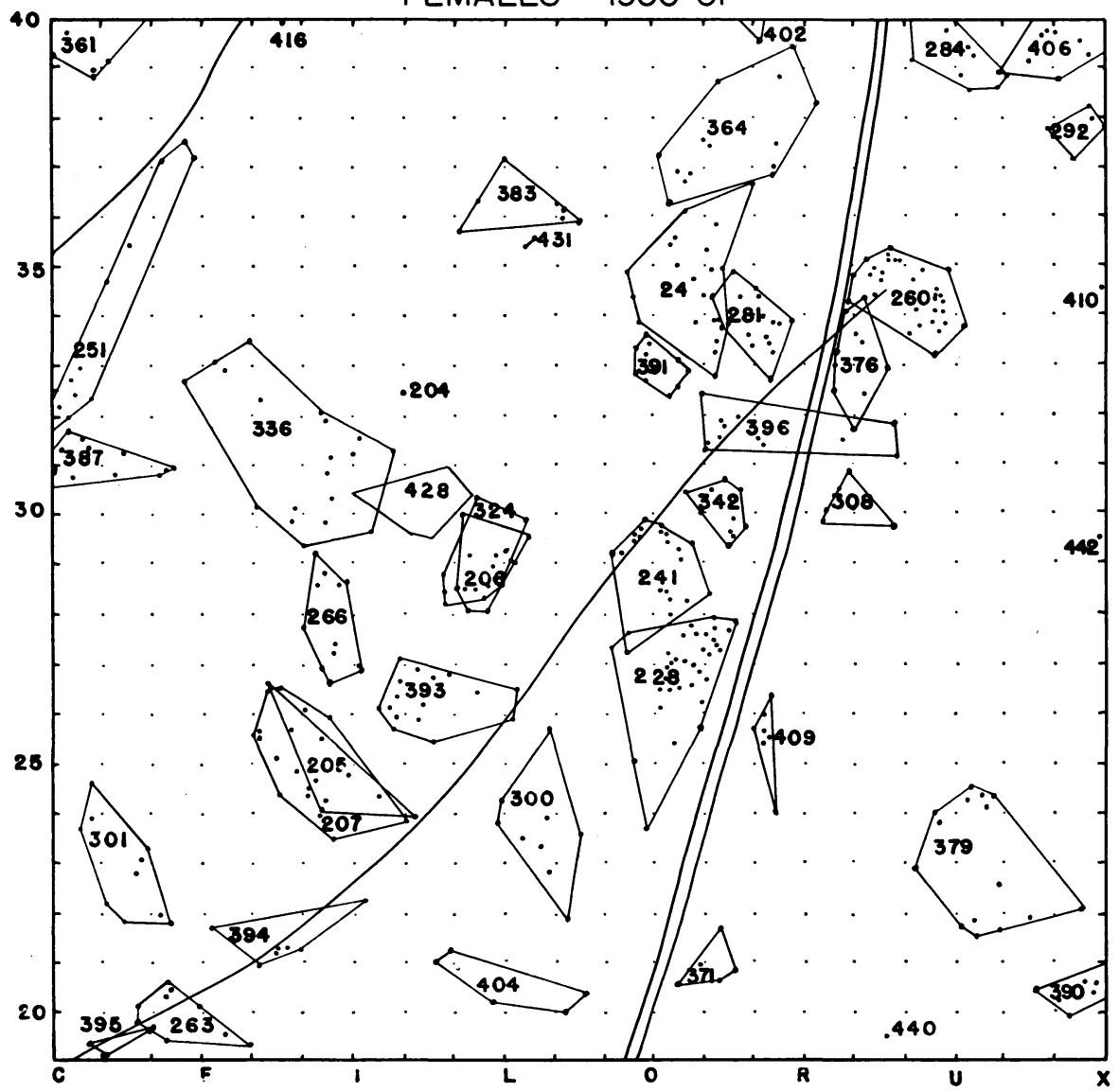

Fig. 30C. Female pocket gopher territories for 1950-51. 


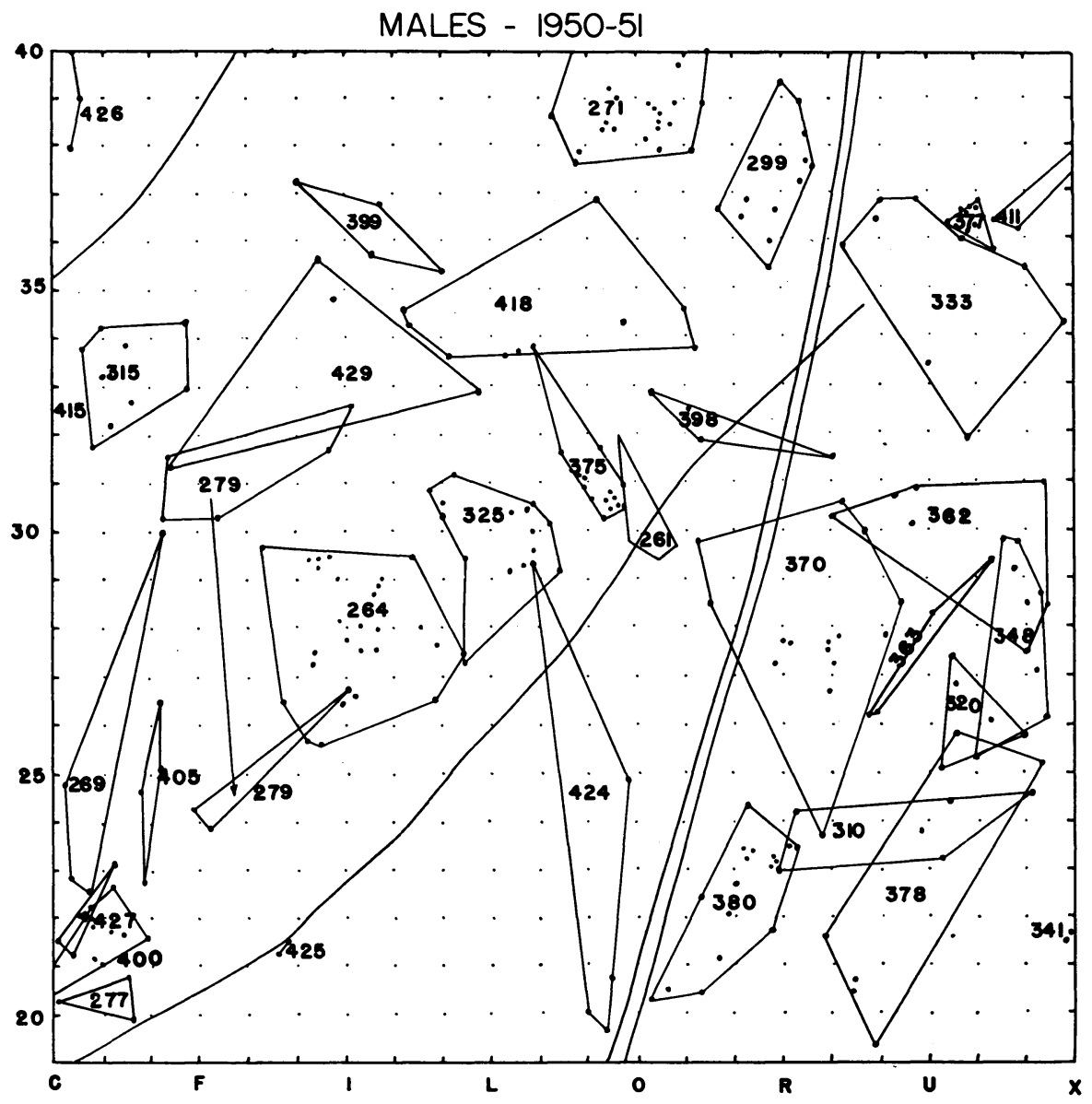

Fig. 30D. Male pocket gopher territories for 1950-51. 
FEMALES - 1951-52

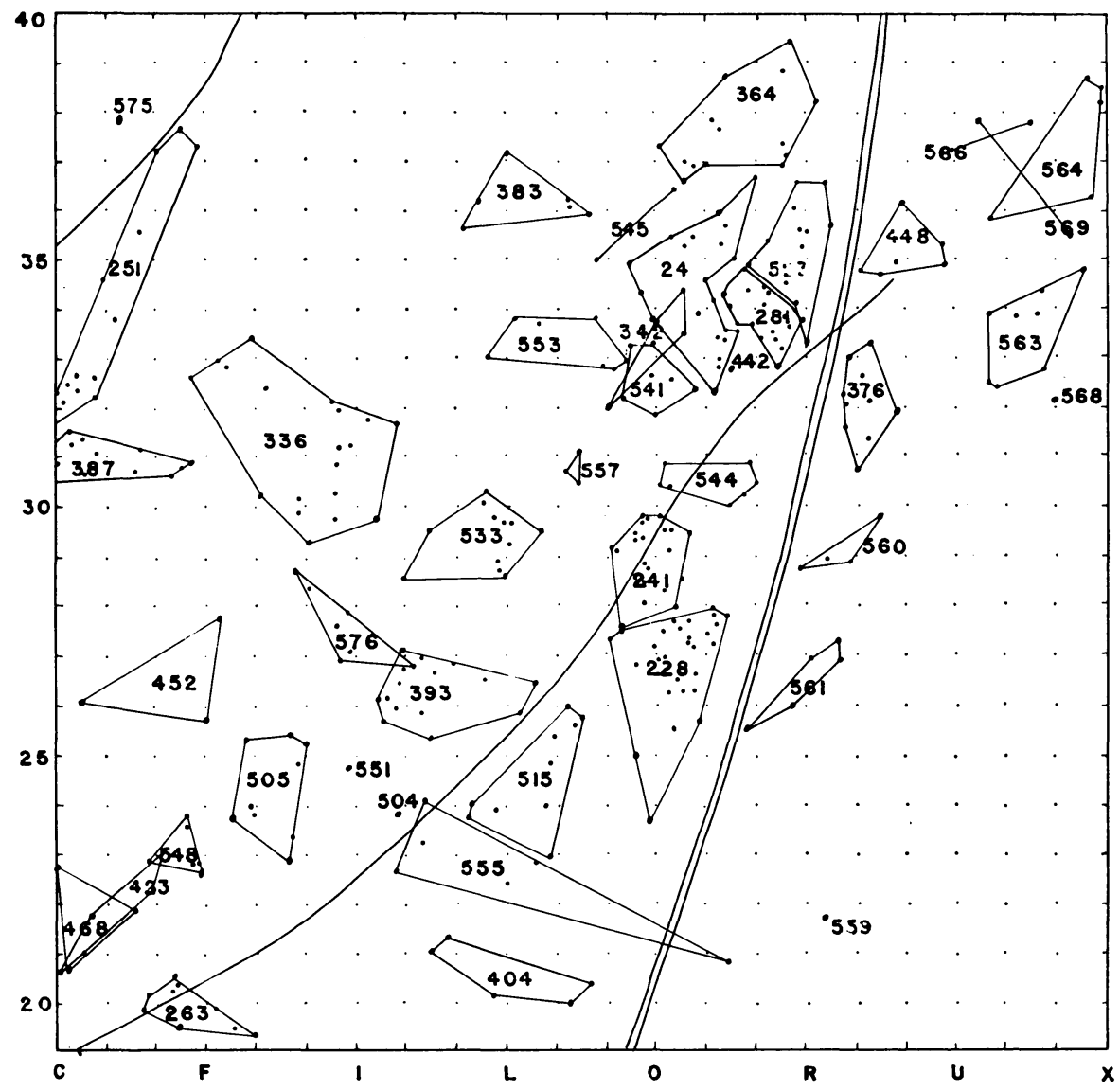

Fig. 30E. Female pocket gopher territories for 1951-52. 


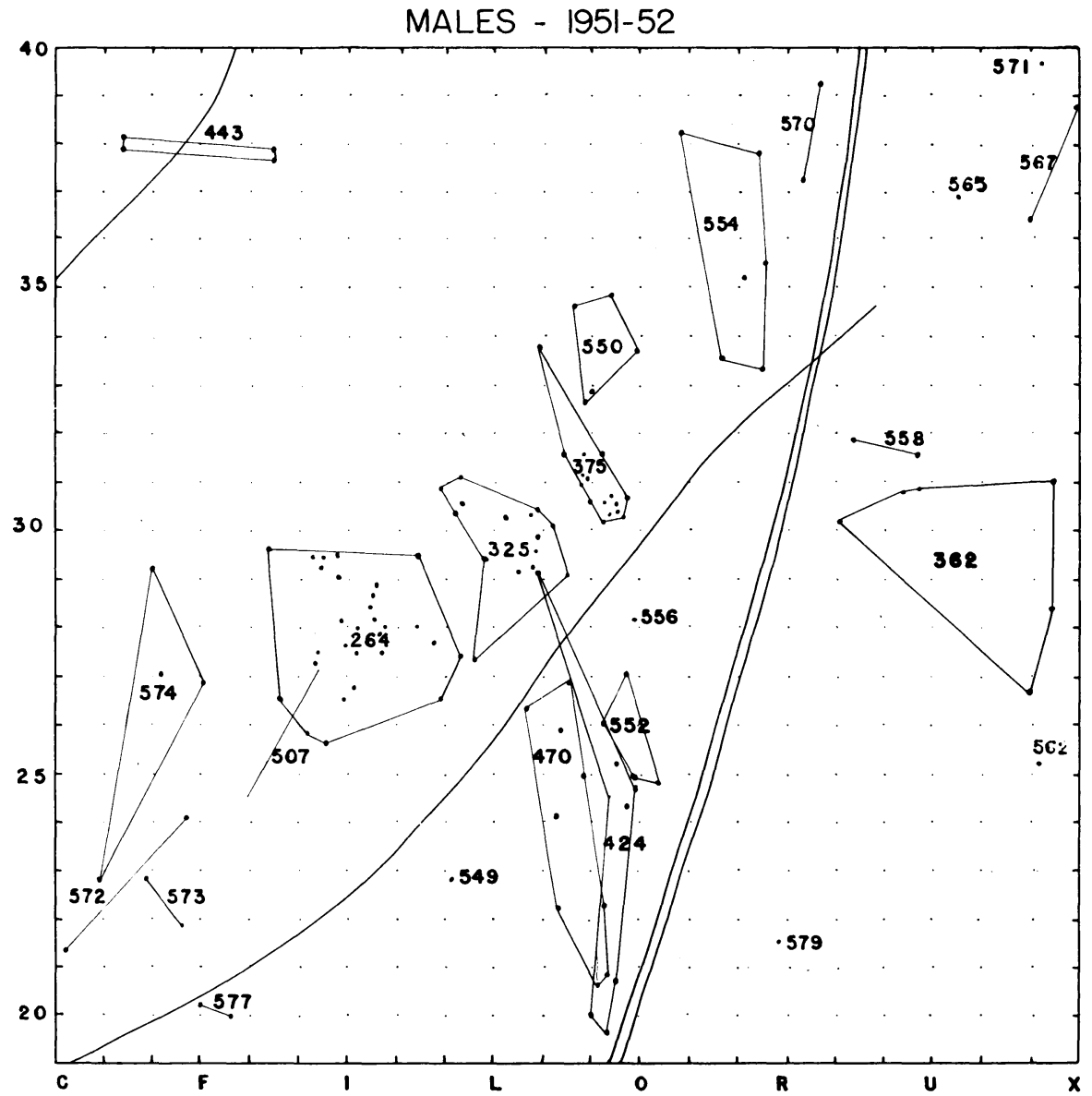

Fig. 30F. Male pocket gopher territories for 1951-52. 


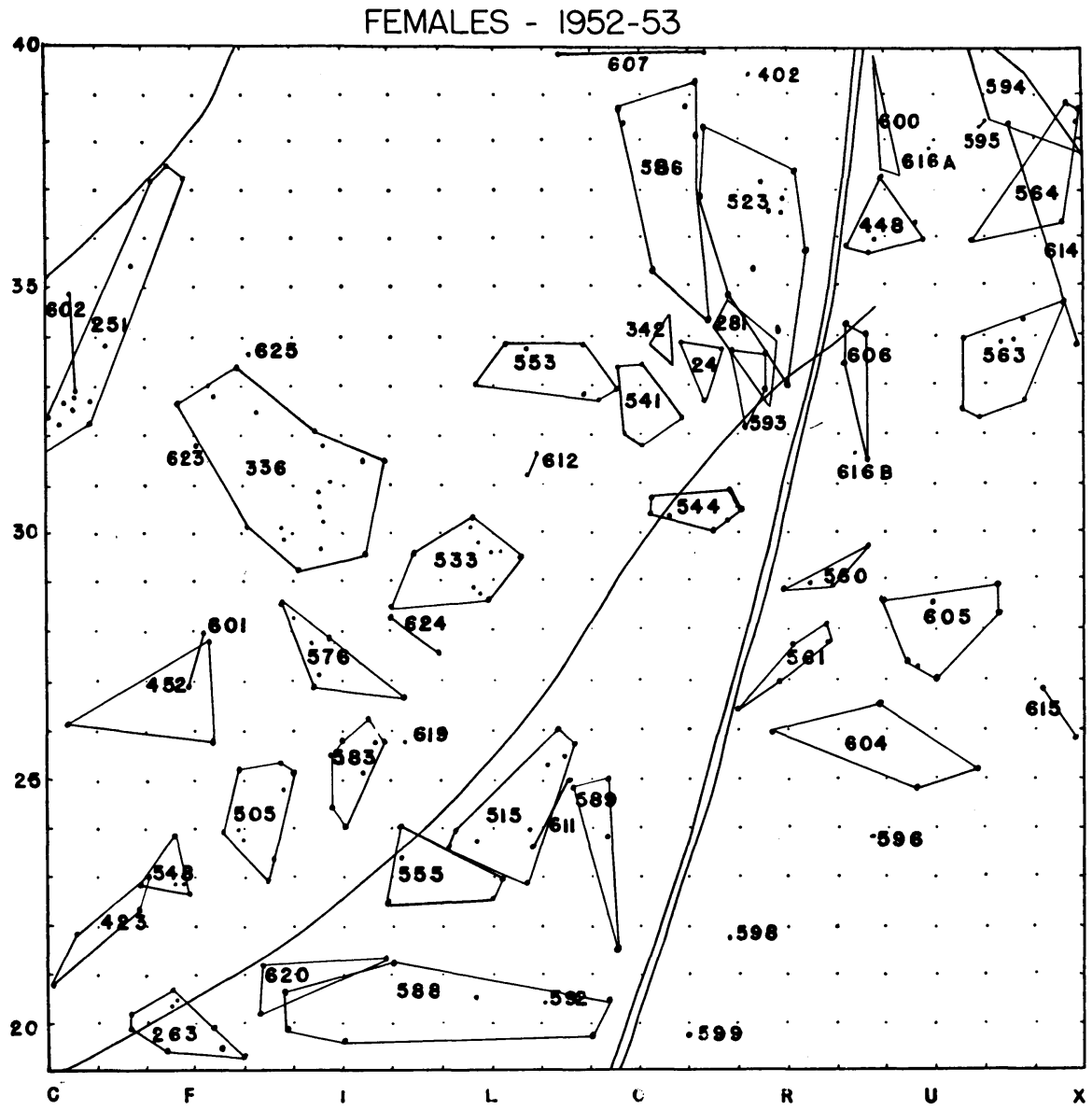

Fig. 30G. Female pocket gopher territories for 1952-53. 


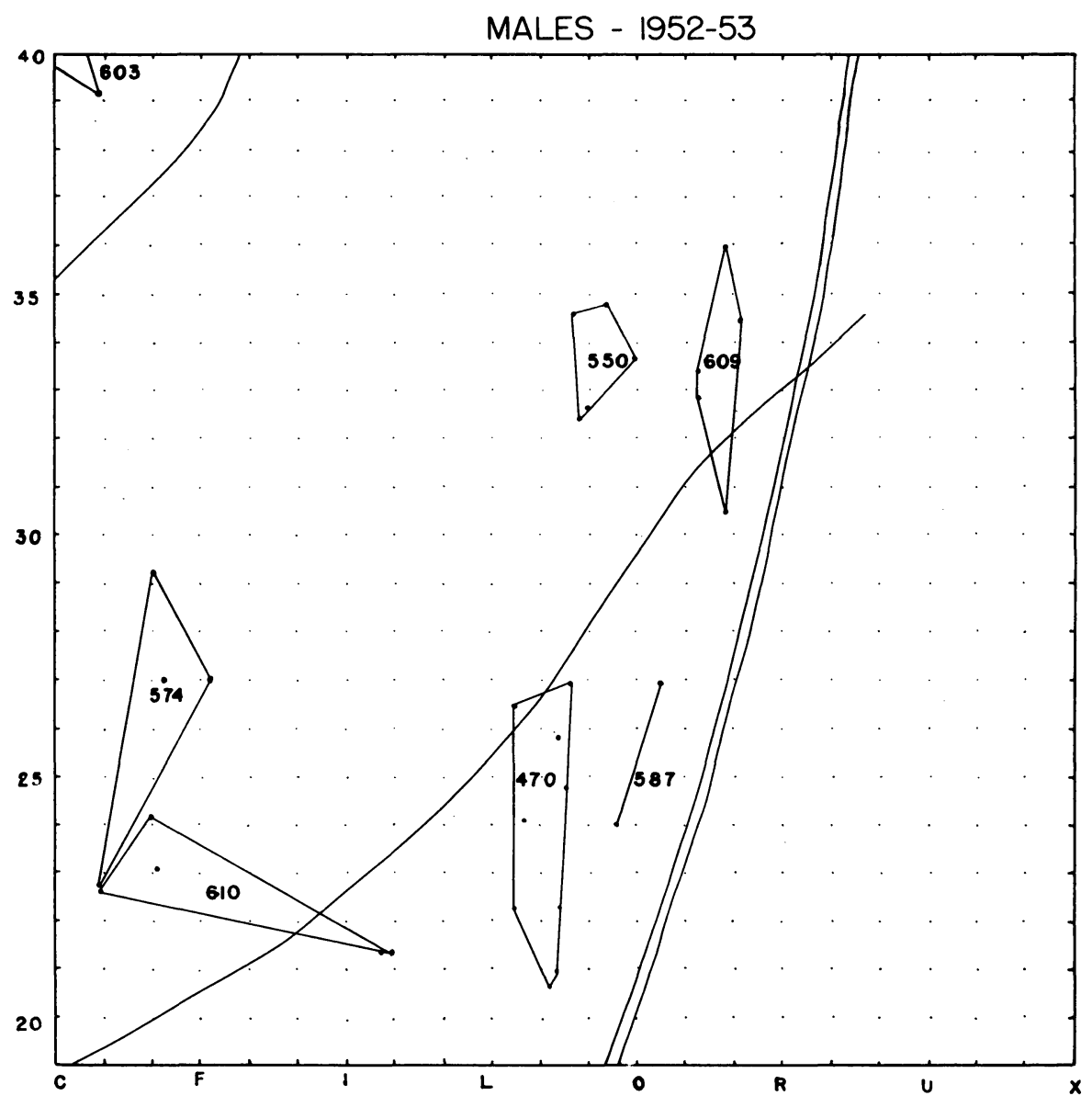

Fig. 30H. Male pocket gopher territories for 1952-53. 
that, male 424, who had been living farther south, moved 110 feet on February 21 or 22 to the south edge of $\mathrm{A}$.

In 1952, male 424 was last trapped in May about 100 feet to the north of area A. Female 228 had extended her range into part of the area south of $\mathrm{A}$ and was last trapped there when 35 months old. She was captured 35 times. Female 241 was last trapped in February still in her territory north of $A$. Male 552 was trapped only twice in 1952, first in A then in area to south of A. Sub-adult male 587 moved 130 feet from his juvenile range into northwest corner of A. Male 470, who was in A as a sub-adult in 1951, was caught in February about 115 feet south of the territory that was south of A, but in April and May he was back in the area just south of A. Female 515 who was also a sub-adult in A in 1951 was in his region just south of A in February; then she moved west to a territory where she remained into 1954. Sub-adult female 589 was first trapped in late November in area just south of A.

On January 6, 1953, male 470 was still south of the area just south of A but on January 31 he was trapped 100 feet to the north in A. In February he was captured in A and the region to the south of A. Adult female 611, in breeding condition, appeared in A in the middle of January. Male 587 moved from $\mathrm{A}$ to adjacent area to the south. Female 589 remained in $\mathrm{A}$ and the area to the south of A until she was kill-trapped in April, 1954.

The function of territoriality among pocket gophers is not to assist in pair formation to the extent found in birds, for male gophers are polygamous. Also territoriality among the gophers seemed to be least pronounced during the breeding season when trespass in birds is not tolerated. There is no indication that males aid females in defending their territories from other females or males. It seems unlikely that they would but we cannot prove this. Whenever a trapped animal was temporarily withheld during the breeding season and another gopher was later captured from the same burrow, it would usually be one of the adjacent neighbors, although two adult males were seldom caught in succession.

We interpret the phenomenon of territoriality in gophers as indicating an intolerance of all other members of the same species regardless of sex. Males are probably more intolerant of other males than of females, but females are perhaps as intolerant of males as they are of other females. During the breeding season females appear to become more tolerant of males and presumably also of other females, but there is no indication that males become either more or less tolerant of other males in the breeding season. We do not know if the places where territories overlap represent areas that are only loosely defended or whether they are actually neutral zones.

We calculated the size of territories on an area basis by connecting the outermost points of eapture during the winter and spring when the population was stable (fig. 30). An objection to this method is that a gopher's territory actually consists of only a branching tube and restricted feeding areas on the ground surfaces surrounding feed holes. In another sense, however, a territory might justly be measured by surface area, since there is a minor shifting of lateral burrows-new ones are dug, old ones plugged—over a 
period of time. At least the location of the shallower tunnels is not static. Little is known about the deeper, more permanent tunnels. It seems possible that some of the deeper burrows, which often are also larger in diameter, may occasionally be used by individuals other than the resident gopher as was pointed out in the section on homing.

TABLE 4

THE AVERAGE SIZE OF TERRITORIES IN RELATION TO NUMBER OF BREEDING SEASONS SURVIVED

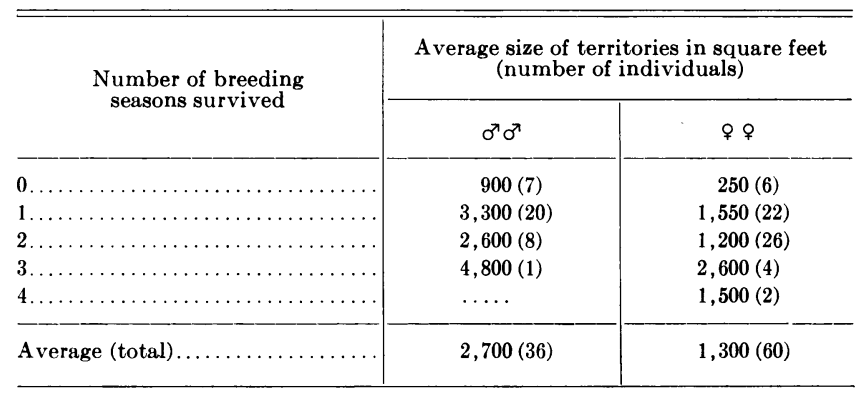

TABLE 5

TERRITORY SIZE VERSUS NUMBER OF CAPTURES

\begin{tabular}{|c|c|c|}
\hline \multirow{2}{*}{$\begin{array}{l}\text { Territory size } \\
\text { (square feet) }\end{array}$} & \multicolumn{2}{|c|}{$\begin{array}{l}\text { Average number of captures } \\
\text { (number of individuals) }\end{array}$} \\
\hline & $\sigma^{\top} \sigma^{\top}$ & ㅇ \\
\hline$\ldots \ldots \ldots \ldots \ldots \ldots$ & $6(12)$ & $8(30)$ \\
\hline $1-2,000$. & $9(6)$ & $15(16)$ \\
\hline $2-3,000$. & $11(5)$ & $18(10)$ \\
\hline $3-4,000$. & $12(3)$ & $16(2)$ \\
\hline $4-5,000$. & $14(3)$ & $21(1)$ \\
\hline $5-6,000$. & $9(3)$ & $11(1)$ \\
\hline $6-7,000 \ldots \ldots$ & $\ldots(0)$ & $\ldots(0)$ \\
\hline $7-8,000 \ldots \ldots \ldots \ldots \ldots$ & $22(2)$ & $\ldots(0)$ \\
\hline $8-9,000 \ldots \ldots \ldots$ & $32(2)$ & $\ldots(0)$ \\
\hline Average (total).. & $11(36)$ & $12(60)$ \\
\hline
\end{tabular}

Territories of males averaged 2,700 square feet, those of females one half that, or 1,300 square feet. As females become older, the extent of their territories usually did not continue to increase appreciably as did some, but not all, of the territories of the males (table 4). In determining territory size, we did not include individuals whose territories may have extended off the plot into places that were not trapped. Also we did not include dispersal distances of young animals. After 15 captures the size of female territories did not increase appreciably, but the more often a male was caught the more likely it was that its territory size would be increased (table 5). Males may have a larger territory because they may serve more than one female. They 
also require more food since they grow to be larger than females of the same age. Of gophers trapped fifteen or more times, heavier females tended to have a smaller territory, but the tendency was less pronounced with males (fig. 31).

Territories of both sexes were not noticeably larger when the population density was low. When an animal dies or disappears, it is thought that the neighboring animals explore the abandoned system. But gophers do not seem to extend their territory permanently over both ranges whenever a neighbor disappears, although there are instances where they may take advantage of

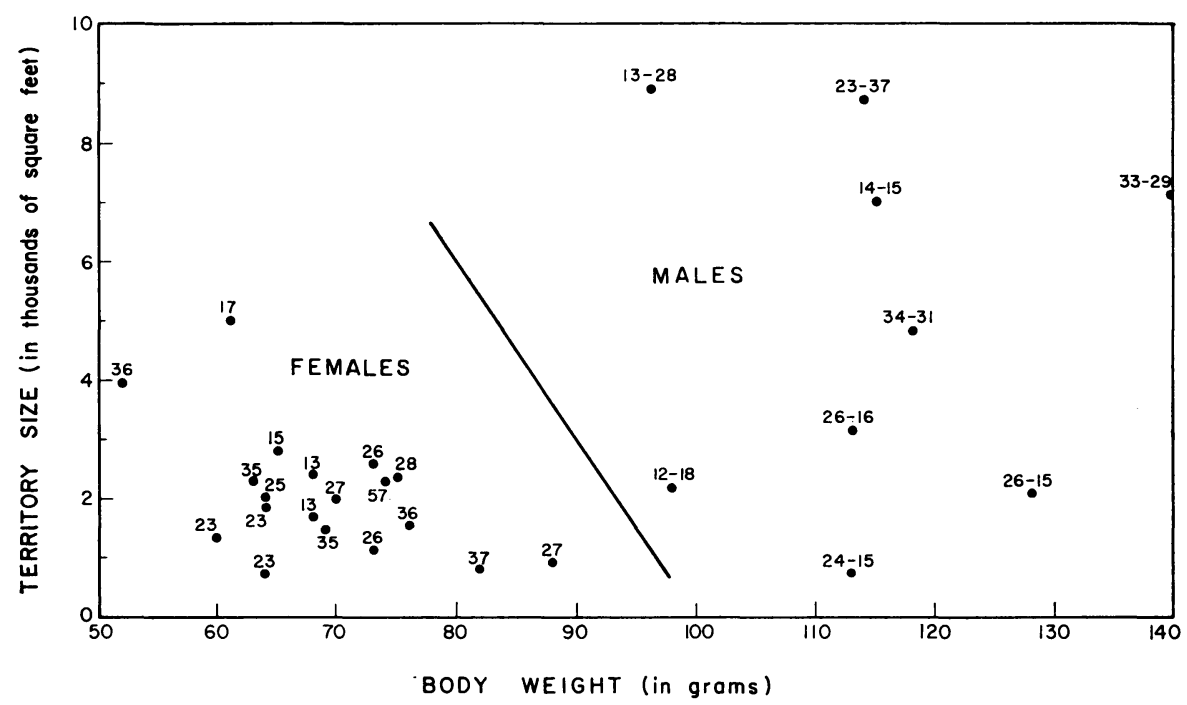

Fig. 31. A comparison of the size of territory with the body weight of male and female pocket gophers trapped fifteen or more times. Weight used is the average of all an individual's November and December weight records for the last year it was trapped during this two-month period. Age, in months, is listed for each female, and months of age and number of captures are given for each male.

part or all of the new habitat by making a shift in their territory boundaries. This type of behavior was particularly noticeable in irrigated lawns around houses at the Experimental Range. Here, removal of gophers often resulted in a new individual moving in within a few days.

Although our gophers were highly territorial, we found an unexpected fluidity within the population. The vacating of a territory from various causes often resulted in the territory being occupied within a short time by another individual. In most cases the new occupant was unmarked, indicating that it came from off the plot. This phenomenon occurred to some extent throughout the year, but was most pronounced in late spring. Age of the new occupants varied but they were primarily sub-adults.

In an experiment on the plot to determine where these new individuals came from, we maintained traps continually in the same holes. At one such 
station 18 gophers were captured between March 10 and May 6, 1953, including two repeats of animals used in homing experiments. Trapping started on March 6 and ended May 29. Only two gophers were caught in May. Nine of the 16 individuals were sub-adults. The seven adults and one recently established sub-adult were marked animals from surrounding territories. The four greatest distances that the marked adults had traveled from the nearest part of their territory to the vacant trap-station area were 110, 100, 85 , and 70 feet.

These data and some of the results of homing experiments with sub-adults would seem to indicate that for a period of time sub-adults can exist within the framework of a gopher population's territorial network and manage to locate themselves in recently vacated territories. This condition seems to exist even though much of the dispersal from their birthplace is also apparently done aboveground. Perhaps these sub-adults live for a time in marginal habitats, which could be between burrow systems within an occupied territory, hence can quickly occupy better sites as they become available. This explanation does not indicate, however, how they find such vacant territories unless their temporary residence was quite tenuous and adjacent to their new territory.

\section{HABITAT FACTORS REGULATING DISTRIBUTION OF TERRITORIES}

\section{Soil}

Of prime consideration in a study of the dynamics of a pocket gopher population is the soil substrate in which the animals must carry out their life functions. It seems fair to postulate that such factors as texture, depth, and fertility of soil may have a bearing on the local distribution and density of gophers. Compact, rock-filled soil may be less suitable than easily tilled loam. Infertile soil may restrict gopher abundance by reducing vegetative growth - the animals' food supply, even if suitable in other ways.

An intensive soil survey of the study plot was therefore undertaken in an attempt to correlate these basic factors with the distribution of gophers on the plot. Soil depths were taken at 484 stakes, 20 feet apart on the study plot. The average depth for each square was then determined by averaging the depths at the four corners (fig. 32). The median depth on the plot is about 2 feet.

Soil profile descriptions and relative density measurements were made at 140 locations on the plot. Six soil series were found to cover the following percentages of the area of the plot: Vista-80 per cent, Hanford-8 per cent, Visalia -7 per cent, Cometa -2 per cent, Fallbrook_-2 per cent, and Sesame-1 per cent (fig. 33). These six soils differ in their physical properties but all, with the exception of Cometa-a sedimentary remnant-are colluvial soils arising in place.

According to Talbot, Nelson, and Storie (1942), about 87 per cent of the land at the Experimental Range consists of residual soils formed in place 
through the decomposition and distintegration of the underlying coarsegrained granitic bedrock. As a general rule, the bedrock occurs at depths varying from about 6 inches to 5 feet from the surface; characteristically the soils are of sandy-loam or stony-sandy-loam textures, of neutral reaction, and of brown or grayish-brown color, with low organic-matter content. Al-

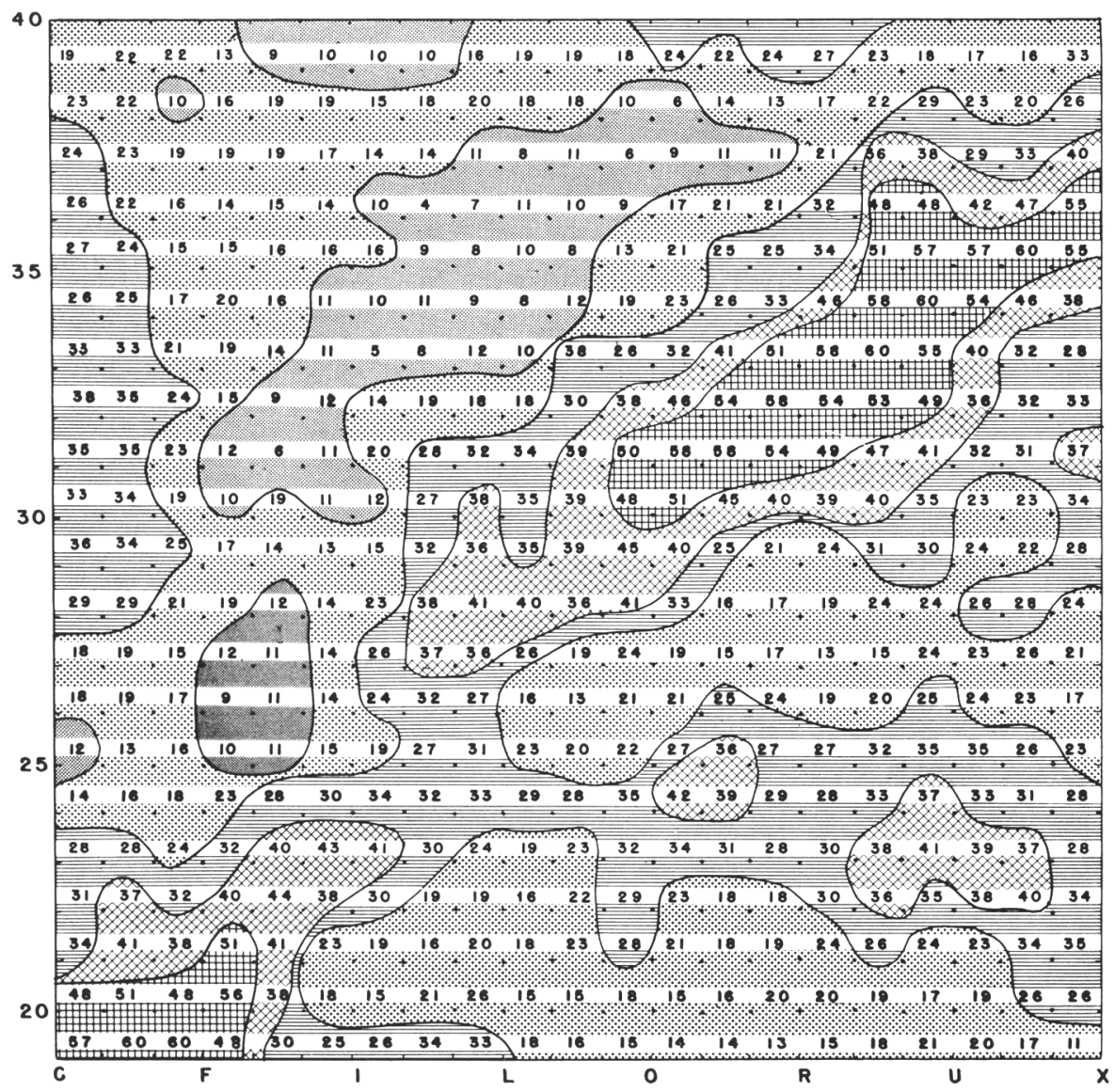

Fig. 32. Average soil depths on study plot. Each number represents the average depth in inches of the four corners of that particular $20 \times 20$-foot square. Depth contours are drawn at 1-foot intervals. The numbered and lettered coordinates of the plot are at 20 . foot intervals.

though the residual soils, mostly of the Vista series, are permeable, their water-holding capacity is low because of their coarse texture and the small volume of soil overlying the bedrock. Consequently, most of the precipitation during the cooler winter months runs off and is of little use to plants. By early summer the moisture content of the upper soil is reduced below the minimum necessary for plant growth, and it becomes extremely difficult for pocket gophers to dig in this hard, dry soil. 


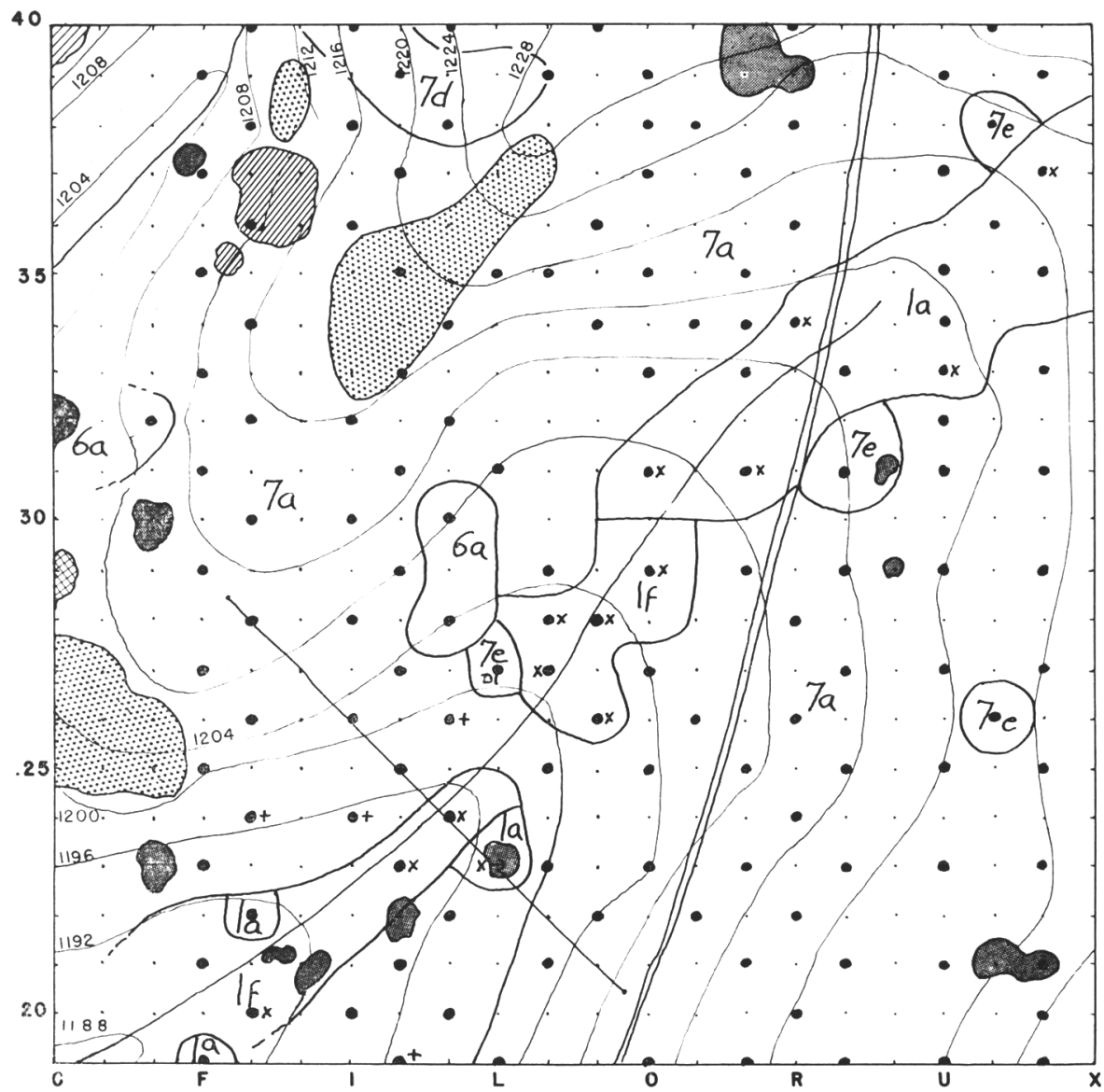

Fig. 33. Soil types, contour lines at 4-foot intervals, location of drift fence (28-F to $20-\mathrm{N}$ ), and woody vegetation on study plot. Soil types were determined at the 140 locations indicated by the large dots. Most of the soil belongs to Vista series (7a), but Hanford (1a), Visalia (1f), Cometa (6a), Sesame (7e), and Fallbrook (7d) are also represented. Unrelated substrata $(x)$ and highly saline $(+)$ conditions are also indicated. The woody vegetation is interior live oak-Quercus Wislizenii (coarse stipple), blue oakQ. Douglasii (fine stipple), Digger pine-Pinus sabiniana (parallel lines), and wedgeleaf ceanothus-Ceanothus cuneatus (crosshatched). The numbered and letter coordinates of plot are at 20 -foot intervals.

Due to the variability in soil types resulting in most gopher territories encompassing more than one soil type, except for Vista series, it was impossible to determine what influence the different types of soils had on the gophers. There was a strong correlation, however, between depth of soil and gopher abundance. They did not live in the shallower soils under 1 foot in depth and were most abundant in soils 2 or more feet in depth. 


\section{Soil Temperature}

Numerous soil and burrow temperatures were recorded with standard thermomenters, maximum-minimum thermometers, and thermocouples inserted in burrows. Apparently there is little air circulation in burrows for their temperatures were always essentially the same as the soil temperatures of

TABLE 6

TYPICAL DAILY MAXIMUM-MINIMUM AND RANGE OF SOIL TEMPERATURES*

\begin{tabular}{|c|c|c|c|}
\hline \multirow{2}{*}{$\begin{array}{c}\text { Depth } \\
\text { (inches) }\end{array}$} & \multicolumn{2}{|c|}{ San Joaquin Experimental Range-August } & \multirow{2}{*}{$\frac{\text { Davis-September }}{\text { No litter }}$} \\
\hline & No litter & Litter & \\
\hline Air & $95-54 ; 41^{\circ} \mathrm{F}$ & $95-54 ; 41^{\circ} \mathrm{F}$ & $91-46 ; 45^{\circ} \mathrm{F}$ \\
\hline $\begin{array}{l}\text { Soil depth } \\
\text { surface }\end{array}$ & $\begin{array}{l}\text { (Shaded) } \\
109-44 ; 65\end{array}$ & $98-61 ; 37$ & $\begin{array}{c}\text { (Not shaded) } \\
\ldots \ldots \ldots \ldots \ldots\end{array}$ \\
\hline $1 / 2 \prime \prime \ldots$. & $\ldots \ldots \ldots \ldots$ & $\ldots \ldots \ldots \ldots$ & $113-54 ; 59$ \\
\hline $3^{\prime \prime} \ldots \ldots \ldots \ldots \ldots \ldots \ldots$ & $\ldots \ldots \ldots \ldots$ & $\ldots \ldots \ldots \ldots$ & $84-69 ; 15$ \\
\hline $4^{\prime \prime} \ldots \ldots$ & $107-81 ; 26$ & $82-73 ; 9$ & $\ldots \ldots \ldots$ \\
\hline $\mathbf{6}^{\prime \prime} \ldots \ldots \ldots \ldots \ldots \ldots \ldots \ldots \ldots$ & $\ldots \ldots \ldots \ldots$ & $\ldots \ldots \ldots \ldots$ & $82-75 ; 7$ \\
\hline $8^{\prime \prime} \ldots \ldots \ldots \ldots$ & $97-89 ; 8$ & $78-65 ; 13$ & $\ldots \ldots \ldots \ldots$ \\
\hline $12^{\prime \prime}$. & $\cdots \cdots$ & $\ldots \ldots \ldots \ldots$ & $77-74 ; 3$ \\
\hline $24^{\prime \prime} \ldots$ & $\begin{array}{l}? \\
\ldots \ldots \ldots \ldots\end{array}$ & $\ldots \ldots \ldots \ldots$ & $76 ; 0$ \\
\hline $36^{\prime \prime} \ldots \ldots \ldots \ldots \ldots \ldots \ldots \ldots$ & $\ldots \ldots \ldots \ldots$ & $\ldots \ldots \ldots \ldots$ & $77 ; 0$ \\
\hline
\end{tabular}

*The double lines indicate the estimated depth gophers would have to be able to reach to escape day-time temperatures. Davis data from Smith (1929).

corresponding depths. The principal temperature-regulation problem facing gophers is to escape from high summer temperatures. Burrows a few inches deep are probably ample protection from cold, whereas access to a depth of 2 feet or more may be necessary in summer if little or no litter is present (table 6). At a depth of about 8 inches on the plot, where litter was present, maximum soil or burrow temperatures in the summer were regularly $10^{\circ}$ to $20^{\circ} \mathrm{F}$ less than maximum air temperatures. When air temperature on the plot reached or surpassed $100^{\circ} \mathrm{F}$, therefore, it seems likely that gophers would have to have access to burrows at least 1 or 2 feet deep. However, we did not determine in the laboratory the maximum temperatures gophers could tolerate for various periods of time. 
TABLE 7

FORAGE YIELD AND SOIL DEPTH ON VISTA SOIL Vista series

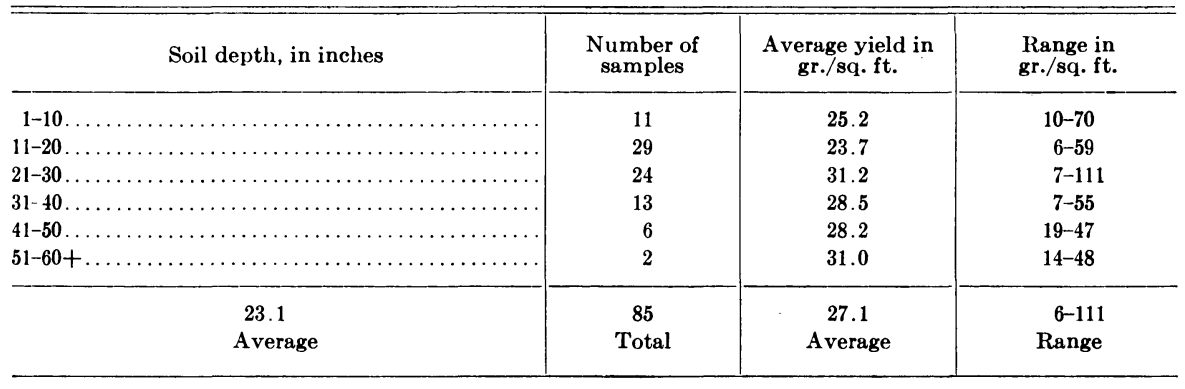

TABLE 8

DRY WEIGHT OF SQUARE-FOOT CLIPPINGS AT FORAGE MATURITY

\begin{tabular}{l|l|l|l|l|l|l|l|l|l|l|l|l}
\hline \hline Stake & D & F & H & J & L & N & P & R & T & V & X \\
\hline
\end{tabular}

May, 1952

3,264 pounds per acre

\begin{tabular}{|c|c|c|c|c|c|c|c|c|c|c|c|}
\hline $39 \ldots \ldots \ldots \ldots \ldots$ & 15 & 11 & 10 & 12 & 21 & 7 & 27 & 35 & 23 & 27 & 22 \\
\hline $37 \ldots \ldots \ldots \ldots \ldots$ & 41 & 27 & 14 & 10 & 11 & 30 & 27 & 34 & 48 & 63 & 37 \\
\hline $35 \ldots \ldots \ldots \ldots \ldots$ & 6 & 30 & 15 & 16 & 54 & 23 & 28 & 48 & 69 & 92 & 14 \\
\hline 33. & 13 & 9 & 7 & 18 & 34 & 34 & 63 & 65 & 57 & 26 & 25 \\
\hline $31 \ldots \ldots \ldots \ldots \ldots$ & 35 & 8 & 7 & 9 & 21 & 53 & 78 & .. & 40 & 50 & $\ldots$ \\
\hline $29 \ldots \ldots \ldots \ldots \ldots$ & 14 & 14 & 14 & 30 & 54 & 90 & 66 & 35 & 55 & 22 & 25 \\
\hline 23. & 19 & 55 & 28 & 29 & 72 & 58 & 21 & 20 & 34 & 27 & 20 \\
\hline $21 \ldots \ldots \ldots \ldots$ & 47 & 63 & 24 & 18 & 33 & 22 & 15 & 40 & 14 & 32 & 33 \\
\hline $19 \ldots \ldots \ldots \ldots$ & 69 & 68 & 78 & 54 & 16 & 41 & 18 & 13 & 9 & 6 & 28 \\
\hline
\end{tabular}

May, 1953

1,728 pounds per acre

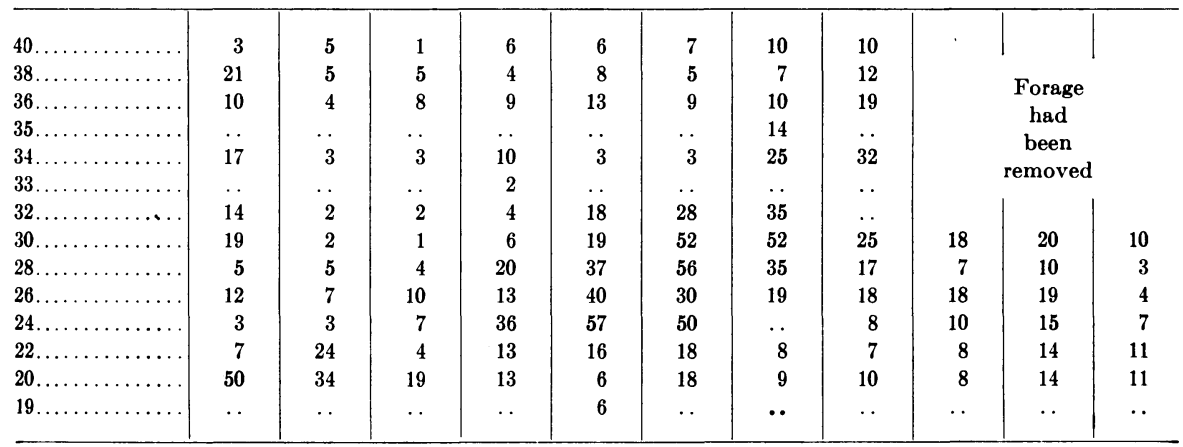


Few gophers lived on the plot where the soil was less than a foot deep. And it is possible that the exceptional occurrence of gophers in shallow soil was the result of faulty depth determinations by striking "floats" in the soil, so that in such instances the soil was actually deeper than recorded. Occasionally runways, perhaps exploratory tunnels, were extended into areas of shallow soil depths. It seems likely that high soil temperature is one reason

TABLE 9

\section{DRY WEIGHT OF HERBACEOUS FORAGE ON 21 SQUARE-FOOT SAMPLES} CLIPPED IN MAY, 1953

\begin{tabular}{|c|c|c|c|}
\hline Herbaceous forage & $\begin{array}{l}\text { Grams per } \\
\text { square foot }\end{array}$ & $\begin{array}{l}\text { Pounds } \\
\text { per acre }\end{array}$ & $\begin{array}{c}\text { Per cent } \\
\text { composition }\end{array}$ \\
\hline Foxtail fescue $\ldots \ldots \ldots \ldots$ Festuca megalura $\ldots \ldots \ldots \ldots \ldots \ldots \ldots$ & 6.43 & 618 & 30.1 \\
\hline Soft chess $\ldots \ldots \ldots \ldots \ldots$ Bromus mollis $\ldots \ldots \ldots \ldots \ldots \ldots \ldots \ldots$ & 4.13 & 396 & 19.4 \\
\hline Whitetip clover. . . . . . . Trifolium variegatum ................. & 2.76 & 265 & 12.9 \\
\hline 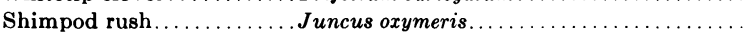 & 2.71 & 260 & 12.7 \\
\hline Broadleaf filaree $\ldots \ldots \ldots \ldots$ Erodium botrys $\ldots \ldots \ldots \ldots \ldots \ldots \ldots$ & 1.98 & 190 & 9.3 \\
\hline Slender oat............ Avena barbata $\ldots \ldots \ldots \ldots \ldots \ldots \ldots \ldots$ & 0.93 & 89 & 4.4 \\
\hline 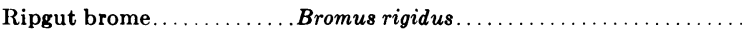 & 0.85 & 82 & 4.0 \\
\hline Quaking grass $\ldots \ldots \ldots \ldots$ Briza minor $\ldots \ldots \ldots \ldots \ldots \ldots \ldots$ & 0.48 & 46 & 2.3 \\
\hline Spanish-clover . ......... Lotus americanus............... & 0.35 & 33 & 1.6 \\
\hline Clovers.............. Trifolium $\mathbf{s p p} . \ldots \ldots \ldots \ldots \ldots \ldots \ldots$ & 0.15 & 14 & 0.7 \\
\hline 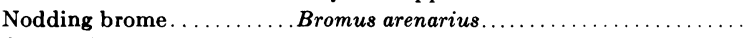 & 0.13 & 12 & 0.6 \\
\hline Ground lupine $\ldots \ldots \ldots \ldots$ Lupinus bicolor $\ldots \ldots \ldots \ldots \ldots \ldots \ldots \ldots$ & 0.09 & 9 & 0.4 \\
\hline Popcorn flower............ Plagiobothrys nothofulvus. . .............. & 0.08 & 8 & 0.4 \\
\hline Common monkey flower....Mimulus guttatus.......... & 0.09 & 9 & 0.4 \\
\hline Red brome................Bromus rubens.... & 0.05 & 5 & 0.2 \\
\hline Chorizanthe............Chorizanthe membranacea. & 0.05 & 5 & 0.2 \\
\hline Mediterranean barley .......Hordeum gussoneanum... & 0.04 & 4 & 0.2 \\
\hline Catch fly $\ldots \ldots \ldots \ldots \ldots \ldots$ Silene gallica $\ldots \ldots \ldots \ldots$ & 0.03 & 3 & 0.1 \\
\hline Linanthus................... Linanthus bicolor. . & 0.01 & 1 & trace \\
\hline Plantain............... Plantago erecta... & trace & 0 & trace \\
\hline ....... Orthocarpus linearilobus. & trace & 1 & trace \\
\hline .......... Lotus strigosus............ & trace & 0 & trace \\
\hline Turkey mullein ..........Eremocarpus satigerus... & 0.01 & 1 & trace \\
\hline
\end{tabular}

why gophers did not live in the shallow soils, but of course in shallow burrows they would also be more vulnerable to bobcats and badgers or other digging carnivores. The amount of vegetation produced in these shallower soils, surprisingly, was not appreciably less than that found in deeper sites (table 7) except, of course, where only a few inches of soil were present.

\section{Vegetation}

It became apparent during the course of the live-trapping on the plot that the distribution of gopher territories was not randcm. Therefore, in addition to evaluating the soil differences, the vegetation on the plot was also studied. In May, 1952, 117 square-foot areas were clipped on the plot at $1 / 4$ of the grid stakes and the dry weight determined (table 8). Average production on the plot was 3,264 pounds of dry-weight forage per acre. Eighty-six similar samples were obtained in 1953 when the average production was 1,728 pounds of dry-weight forage, or only 53 per cent of what it was in 1952, 
which was the best combined grass and legume year at the Range during the gopher study.

Twenty-one of the forage samples collected in 1955, representing two transects across the plot along row 30 and row $\mathrm{N}$, were analyzed for weight and species composition (table 9 ). The results of this material are illustrated graphically in figure 34 .

PROFILES
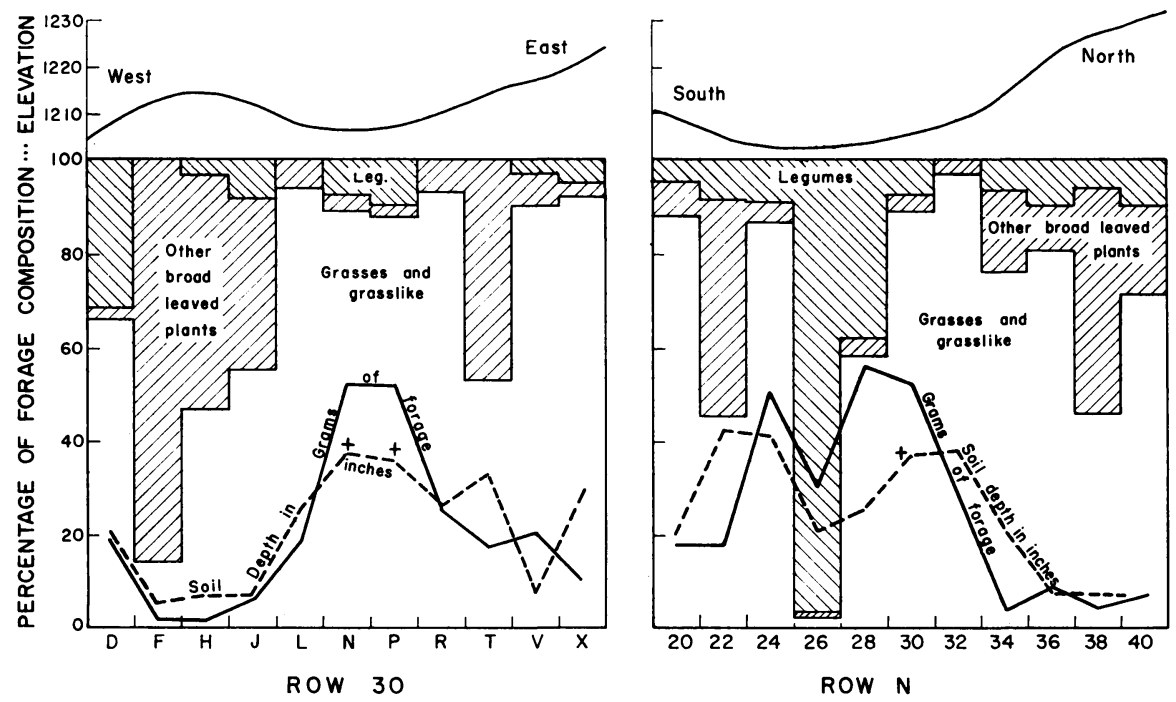

Fig. 34. Production of grasses and grasslike forage, legumes, and other broad-leaved plants on each of 21 square-foot sites along two perpendicular transects on the gopher plot in May, 1953. Depth of soil, grams of herbaceous forage, and contour profile for the transects are also given. (See table 9 for species composition.)

Female weights were, on the average, heavier on the deeper soil where more vegetation was produced, but the differences were not statistically significant. Similarly, there was no significant difference in the mean weights of females or males in the same month or season in different years, although the data suggest there may have been a real difference. Better techniques, however, are needed to measure the difference. Live weights are not adequate because of the variable contents of the alimentary tract. The main difficulty encountered with the plot was that it was so diversified in habitat conditions that the territories of individual gophers often ranged over several soil types and through sites producing different amounts of herbage. We had no way of knowing how much time the animals spent in the different parts of their territories.

The weights of female gophers kill-trapped in the irrigated gardens around the homes at the Range in October and November were significantly heavier than females kill-trapped at the same time in the pastures. 
Comparison of Weights, in Grams, of Female Gophers Kili-Trapped in Yards ANd in Pastures

\begin{tabular}{|c|c|c|c|}
\hline $\begin{array}{c}\text { Number of female } \\
\text { gophers }\end{array}$ & $\begin{array}{l}\text { Mean and stand. } \\
\quad \text { ard error }\end{array}$ & $\begin{array}{l}\text { Standard } \\
\text { deviation }\end{array}$ & $\begin{array}{l}\text { Coefficient } \\
\text { of variatio }\end{array}$ \\
\hline \multicolumn{4}{|c|}{ OCtOBber AND Novenber } \\
\hline $\begin{array}{llll}\text { Yards } \ldots \ldots \ldots & 15 \\
\text { Pastures } & \ldots & \ldots & 18\end{array}$ & $\begin{array}{l}88.5 \pm 3.5 \\
65.8 \pm 2.6\end{array}$ & $\begin{array}{l}14.3 \\
10.9\end{array}$ & $\begin{array}{l}16.1 \\
16.5\end{array}$ \\
\hline \multicolumn{4}{|c|}{ MARCH $A N D$ APRIL } \\
\hline Yards ....... 12 & $88.0 \pm 3.2$ & 10.9 & 11.0 \\
\hline Pastures .... 48 & $84.5 \pm 1.8$ & 12.6 & 14.9 \\
\hline
\end{tabular}

$\Lambda$ the conclusion of the major part of the study, the forage in the northeastern corner of the plot (table 8) was killed with herbicides and then burned. This greatly reduced the number of animals in the area. Some of the borderline individuals made a slight shift of their territory while others in the middle of the bare area disappeared. Whether the influence was due primarily to the loss of feed or to the loss of cover was not determined.

\section{PREDATION}

The role played by vertebrate predators in determining density of a pocket gopher population is not completely understood. A plausible hypothesis, however, is that predators are of comparatively minor significance. Type and depth of soil, weather, and vegetation seem to be the primary factors regulating pocket gopher densities. This is in agreement with Errington (1946), who states that the physical makeup of the habitat is the important factor. This will be discussed more fully in a later section on population dynamies.

At the San Joaquin Experimental Range, as elsewhere, the rodent population is more instrumental in determining the density of its predators than vice versa (Howard, 1953c). Obviously, if predators could keep their important prey species at low population levels, even though other factors of the habitat were optimum for the prey, few predators would then be able to survive. Rodents will, of course, probably become more numerous, at least for a time, if most of their principal predators are greatly reduced in numbers. But the basic density of gophers is primarily determined by other conditions of the habitat rather than by any one of the many species of predators. Other gophers seem to be the most important vertebrate limiting their numbers.

For convenience we refer to the basic density of pocket gophers that a given environment supports as the carrying capacity of that habitat for gophers. Gophers in excess of this carrying capacity, or basic density of the population, are called the biological surplus. When conditions of the habitat (exclusive of predation) become more favorable for gophers, then both the carrying capacity and the biological surplus increase. Consequently, the more favorable the habitat, the greater is the production of gophers, the higher is the habitat's carrying capacity for gophers, and the greater is the number of gophers (biological surplus) that are "available" to predators. For example, when a gopher habitat is greatly improved, as when planted 
to alfalfa, the gopher population usually increases manyfold, and this will oceur regardless of whether or not there is a similar increase in number and kinds of predators.

$\Lambda$ the Experimental Range each species of rodent has numerous species of predators. Likewise, these predators have many alternate species of prey. On the basis of other investigations at the Range (Fitch, 1940, 1947, 1948, 1949; Fitch, Swenson, and Tillotson, 1946 ; and Fitch and Twining, 1946), the following classification of six gopher predators can be made. The list is arranged in the order of decreasing importance as a predator of gophers at the Range. The percentage indicates the gopher content, by weight, of the diet of each predator.

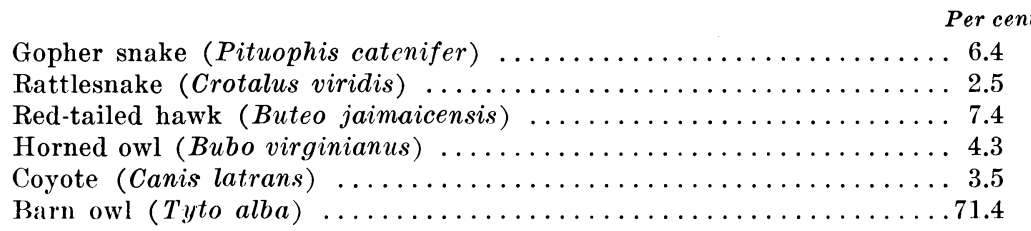

Even though the pocket gopher comprised 71.4 per cent by weight of the barn owl's diet, these birds are so rare at the Range that they are insignificant as a check on gopher numbers.

The coyote is the only mammalian carnivore for which data are available and gophers comprised only 3.5 per cent of its recorded prey. Skunks, foxes, badgers, and bobcats may actually be more important than some of the other animals listed. Since domestic cats at the Experimental Range are known to catch many gophers, including adults, its seems likely that bobcats in particular may feed extensively on gophers. Sub-adult gophers dispersing aboveground are highly vulnerable to predation. The aggressiveness or territorial behavior in adults may also cause some adults to expose themselves to aboveground predators. This situation is probably more common when the gopher density has reached the carrying capacity of the area.

We strongly suspect that the most important predators of adult pocket gophers are mammalian carnivores. When someone learns how to identify the age of a gopher adequately from its skeleton, it will then be possible to examine hawk and owl pellets and carnivore scats to see if they contain remains of many adult gophers. It is possible that these predators feed for the most part on juvenile and sub-adult animals caught while wandering aboveground before they have established their territory. We do not know if hawks or owls catch many adult gophers in the act of pushing dirt aboveground or feeding from feed holes, but they may. By observing, behind glass, rattlesnakes in gopher burrows, it was obvious that a rattlesnake must wait outside the burrow before it can strike an adult gopher. Young might be eaten in the nest, but a gopher tunnel is too confining to permit a snake to strike. It was interesting to observe through the glass that even though a gopher gave way to a rattlesnake coming through its tunnel, it was not very frightened and would attempt to drive the snake away by pushing dirt toward it. In several tests neither snake nor gopher was injured. 


\section{PARASITES}

No ticks or fleas were observed on any of the gophers at the Range even though a careful search was made for them. Tryon (1947) reports them as common on Thomomys talpoides in Montana. R. S. Miller (correspondence) says that the Thomomys he is studying in Colorado is invariably infested with fleas and quite often ticks and warbles as well. Others also have found fleas on gophers. The junior author found fleas on T. monticola above the Experimental Range at about 7,000 feet. At the Range one species of louse (Trichodectes geomydis) and three species of mites (Trobicyla californica, Haemolaelaps geomys, and Hirstionyssus geomydis) were frequently found on gophers. Most of the adults had several tapeworms (Hymenolepis horrida), and one animal had 108 immature tapeworms with short strobila. None of the five juvenile gophers examined had tapeworms. Even though an occasional warble had been reported in gophers by Moore and Reid (1951) and Tryon (1947), none was observed in animals at the Range.

\section{ANIMAL ASSOCIATES}

No other rodent in the western United States digs burrows so frequently and so extensively as do pocket gophers. In fact, in California these animals probably dig more than all the other 88 or so species put together. Consequently, many different species of rodent and other animals not so well adapted for digging are quick to utilize portions of abandoned gopher tunnels as their own home. Even ground squirrels are prone to enlarge unoccupied gopher burrows for their own use, but we have no evidence of either species driving the other from its burrow system. Scheffer (1954) reports on other kinds of animals found in runways of the mole, which is not a rodent but is an insectivore that makes extensive tunnels and also lives a fossorial existence.

From time to time other vertebrates were captured on the study plot in live traps set for gophers. These include the tiger salamander (Ambystoma tigrinum), deer mouse (Peromyscus maniculatus), pocket mouse (Perognathus inornatus), kangaroo rat (Dipodomys heermanni), whiptail lizard (Cnemidophorus tigris), and gopher snake (Pituophis catenifer). One gopher snake was caught in the same trap along with an uninjured adult female pocket gopher. (The snake weighed 101 grams and was $880 \mathrm{~mm}$ long from snout to tail tip. It was caught fast with about $150 \mathrm{~mm}$ of the head end out of the trap). Cave crickets were occasionally seen in burrows when traps were being set. Many of the other burrow-inhabiting vertebrates present at the Range (Childs and Howard, 1955) also have been presumed or known to have occupied gopher tunnels.

\section{DISCUSSION}

\section{Population Fluctuation}

In this section we attempt to integrate the inherent group attributes of pocket gophers with the various climatic, edaphic, and biotic factors of the 
"ecosystem" (Evans, 1956) that may play important roles in determining the variations observed in the structure of the gopher population on the plot. Even though it may not be possible to understand all of the factors responsible for the annual variation in the population structure, to be presented later with regard to density, sex ratios and age ratios (fig. 35), it is possible to deduce certain interrelationships between both the individuals and the community of pocket gophers and the dynamic complex of the ecosystem as a whole. In preparing this section we have consulted the important works by Solomon (1949), Allee et al. (1949), Andrewartha and Birch (1954), Dice (1952), Lack (1954), Odum (1953), and others.

The average litter size was 4.6 , but we have arbitrarily taken five young per year as the average annual female production rate, since we believe a few individuals produced two litters per season and no adult female was known not to have bred. More information about natality among the gophers might have revealed some significant factors, however, regarding variations in the "realized" natality of the population in different years. Any appreciable drop in the average number of offspring produced annually by each female, would certainly have a pronounced effect on the density of gophers. For example, a drop from five to three immatures would mean a drop of 11 per cent in the proportion of females that year that were immatures. Since the observed productivity of the gophers is adequate to at least double the population density in one year, as was done in 1950, a 50 per cent lessening of the average number of offspring per female below five individuals would be far more significant in altering the population structure than would be a similar increase in fecundity per year. The per cent of immatures of each sex increases progressively more slowly as the annual number of offspring produced per female becomes greater.

On the plot the male:female sex ratio of breeding adults for the year 1949-1954, respectively, were $1: 1,1: 1.7,1: 1.3,1: 2,1: 4$, and $1: 3$. This variation alters the percentage of males following breeding that will be immatures. It affects only males because they are polygamous. For example, with a 1:1 ratio the immatures will make up 71 per cent of both sexes, if there are five young per litter. When the sex ratio is $1: 4$ the percentage of females that are immature will still be 71 per cent but 90 per cent of the males will be immatures. The percentage of breeding adults in different age classes varied each year. In 1953, 31 per cent of the breeding adults in January were two years old whereas in 1951 only 13 per cent (fig. 36) were. It would also appear that sexual strife occurs in males with the onset of breeding since the male percentage of the population is always least at the beginning of breeding (fig. 37).

In 1950 , following the population low of 1949 , the gopher density did not recover to the apparent optimal density for the site, which it would probably have approached more closely if fecundity had been increased several-fold. But perhaps this degree of stabilization is more beneficial to the population in the long run, thus favored by natural selection. Nevertheless, the highest rate of survival for immatures did occur during 1950, the year when the carrying capacity of the site was at its best. But the fact that the density 


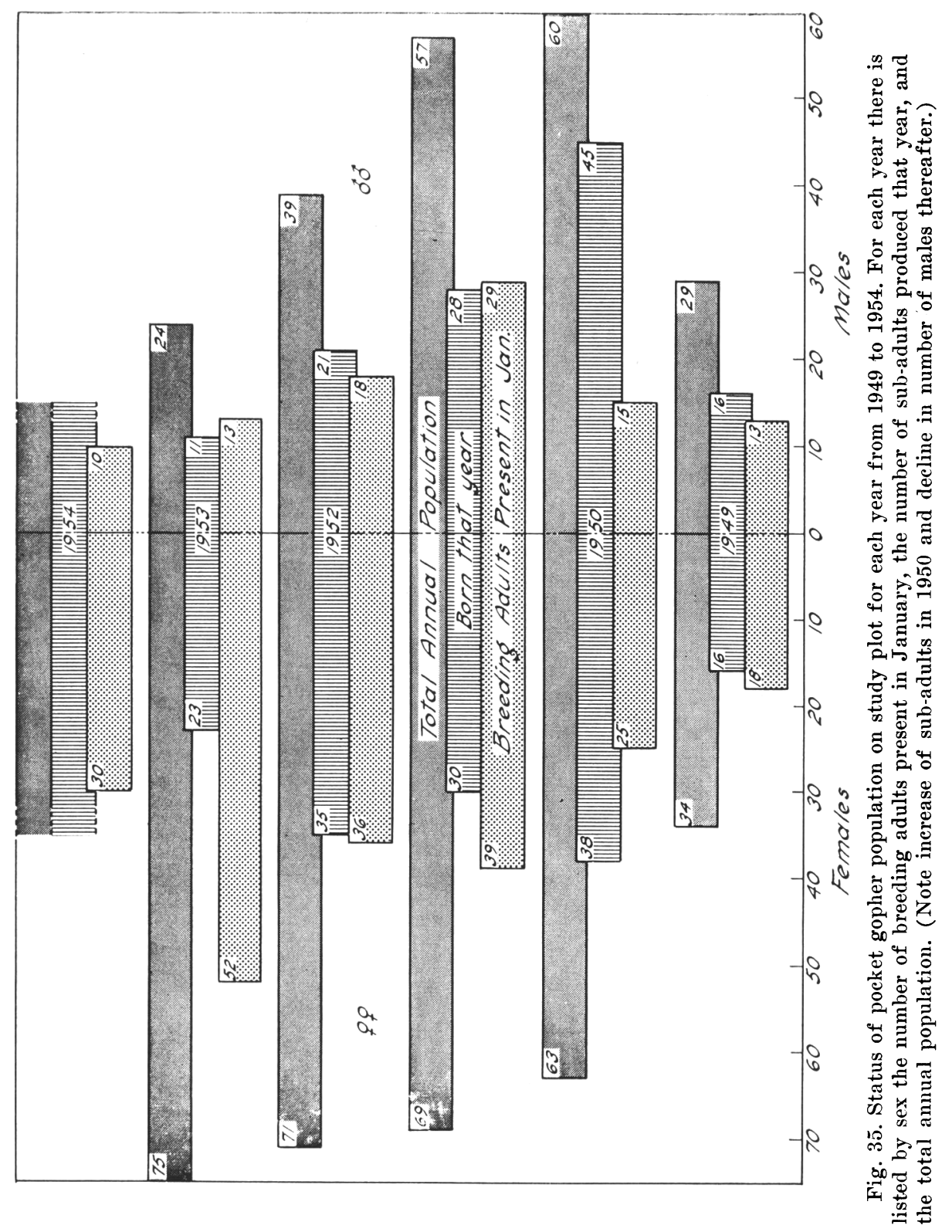




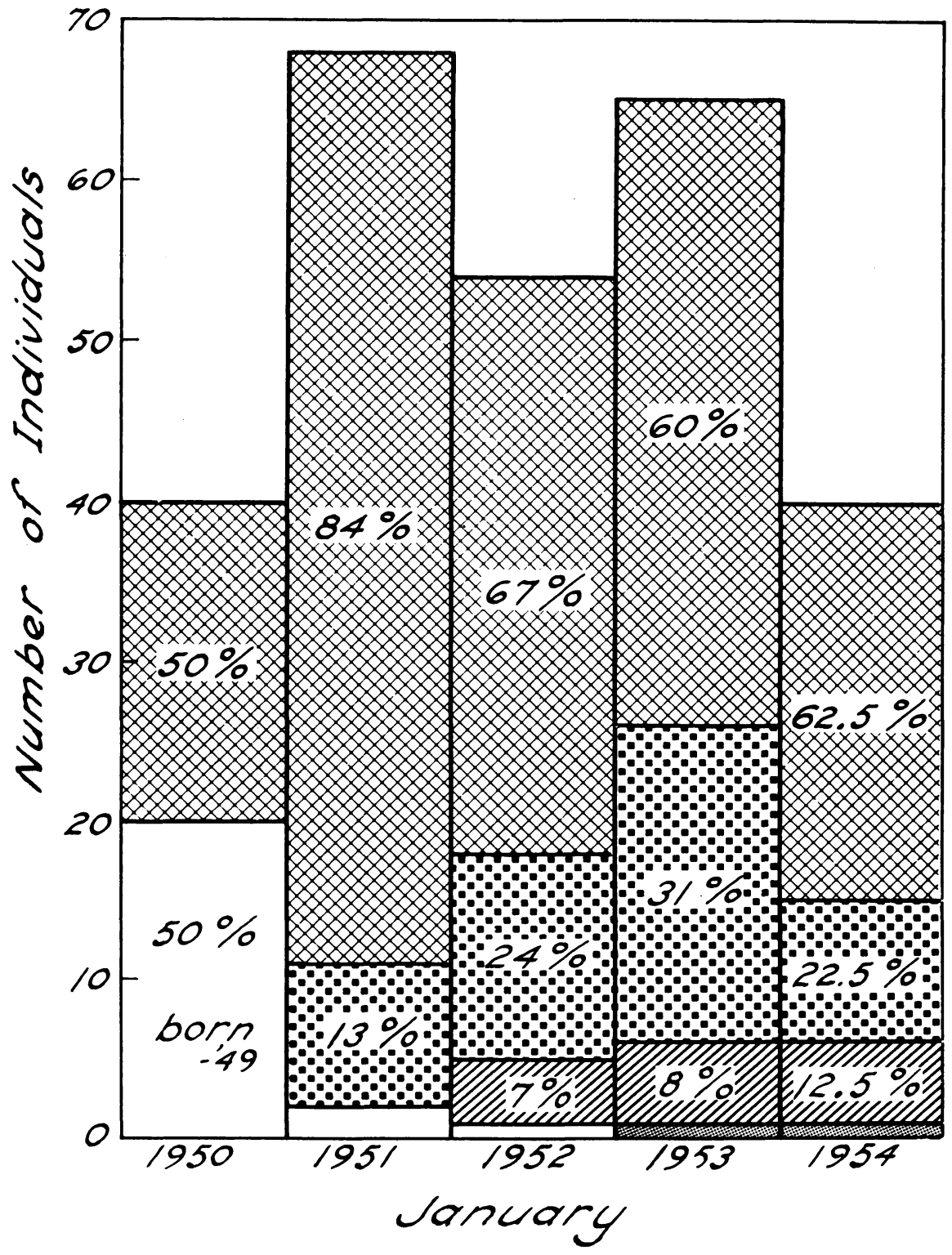

Fig. 36. The density of adult population (the pocket gopher breeding population) that was present on the study in January of each year classified according to the per cent in each age class; e.g., in 1953, 60 per cent were one year of age, 31 per cent, two years old, 8 per cent, three years, and 1 per cent, four years old. 
of gophers in 1949 was low is probably an even more important factor favoring a high rate of survival of immatures in 1950.

The percentage of gophers in different age classes in any given year does not in itself give a reliable indication of whether or not the population as a whole of each sex will be increased or decreased that year. This is borne out

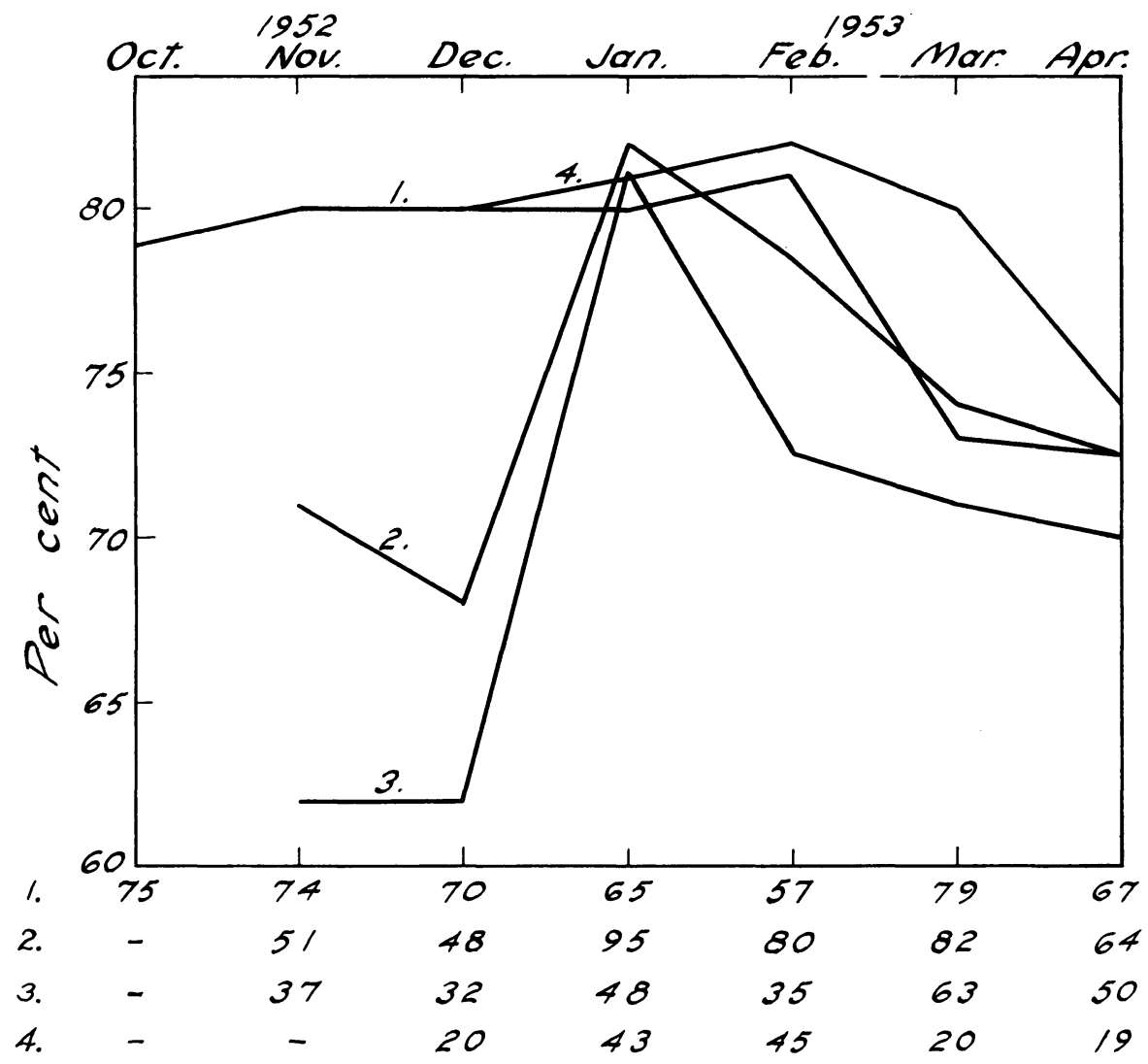

Fig. 37. A comparison of the percentage of the pocket gophers which were females when compared at monthly intervals for four situations: 1. animals known to have been living on the study plot; 2. gophers obtained anywhere on the Experimental Range; 3. individuals kill-trapped (Macabee trap), mostly adjacent to plot; and 4. gophers live-trapped on plot. The number of individuals of both sexes used in calculating the percentages are listed. Some animals appear in both columns 3 and 4 .

by figure 38 , which compares the age pyramids with known percentages on how much the density of each sex increased or decreased each year. An example of what a stable population is like is also shown for the five-year average of the polygamous males and as a logistic curve for females, since 71.4 per cent of females each year are immatures, if each female produces an average of five young each year of an equal number of males and females. 


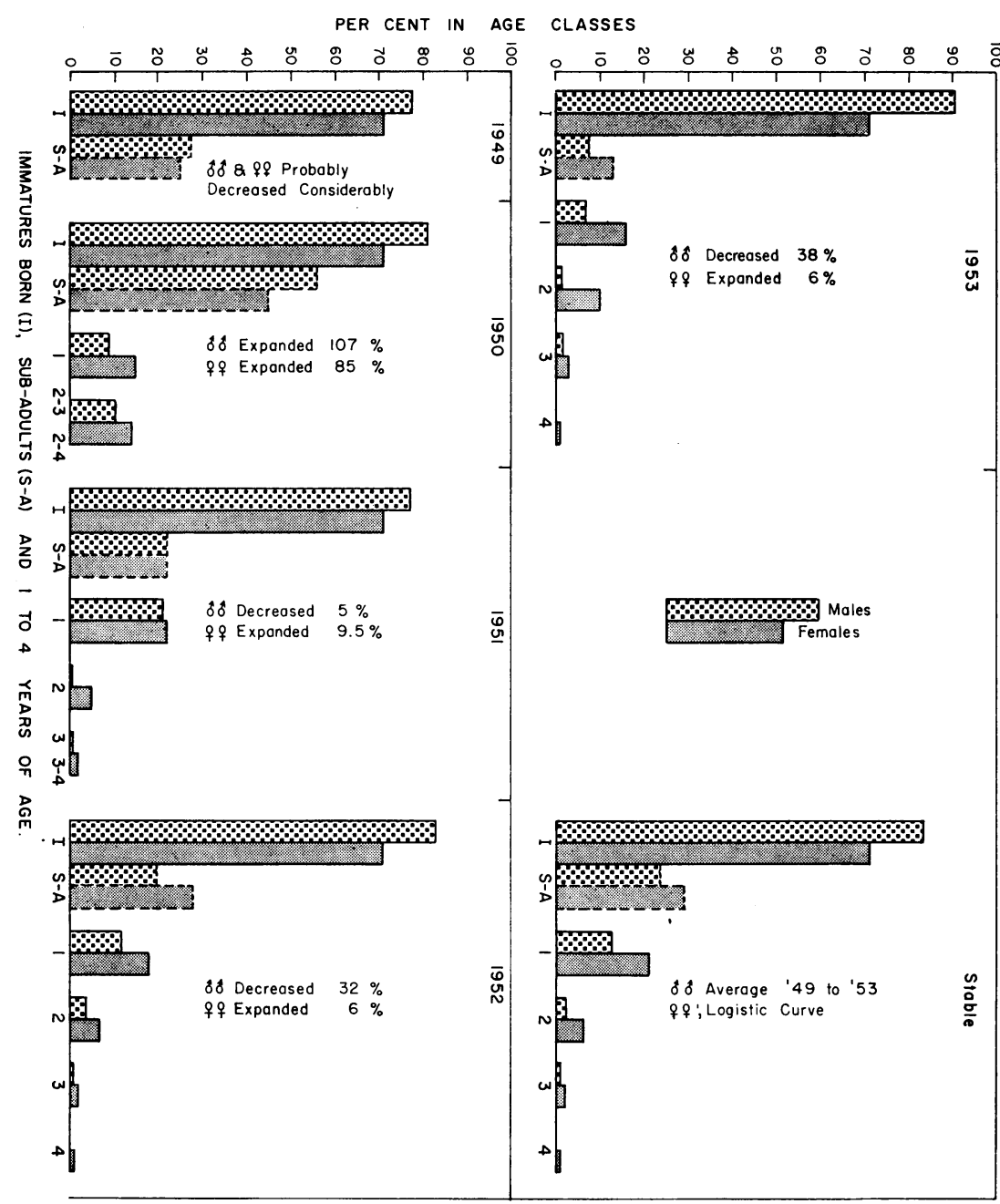

Fig. 38. A comparison between the per cent of males and females in different age classes for each year on gopher plot and their percentage change in density. Sub-adults represent that portion of the estimated number of immatures born that survived long enough to be trapped at least once as sub-adults.

The difficulty of using age pyramids as an indication of population stability is due to several causes. With a high rate of survival in 1950, a high percentage of the immatures lived to become sub-adults. Since there was a low rate of increase in 1949, the one-year-olds in 1950 were no more numerous than the two-to-four years of age. Likewise, in 1951 there was a high percentage of one-year-olds because of the high rate of increase in 1950. The percentage of females in the figure that are new-born is always 71.4, because we have assumed that each adult female averaged five offspring each year. 


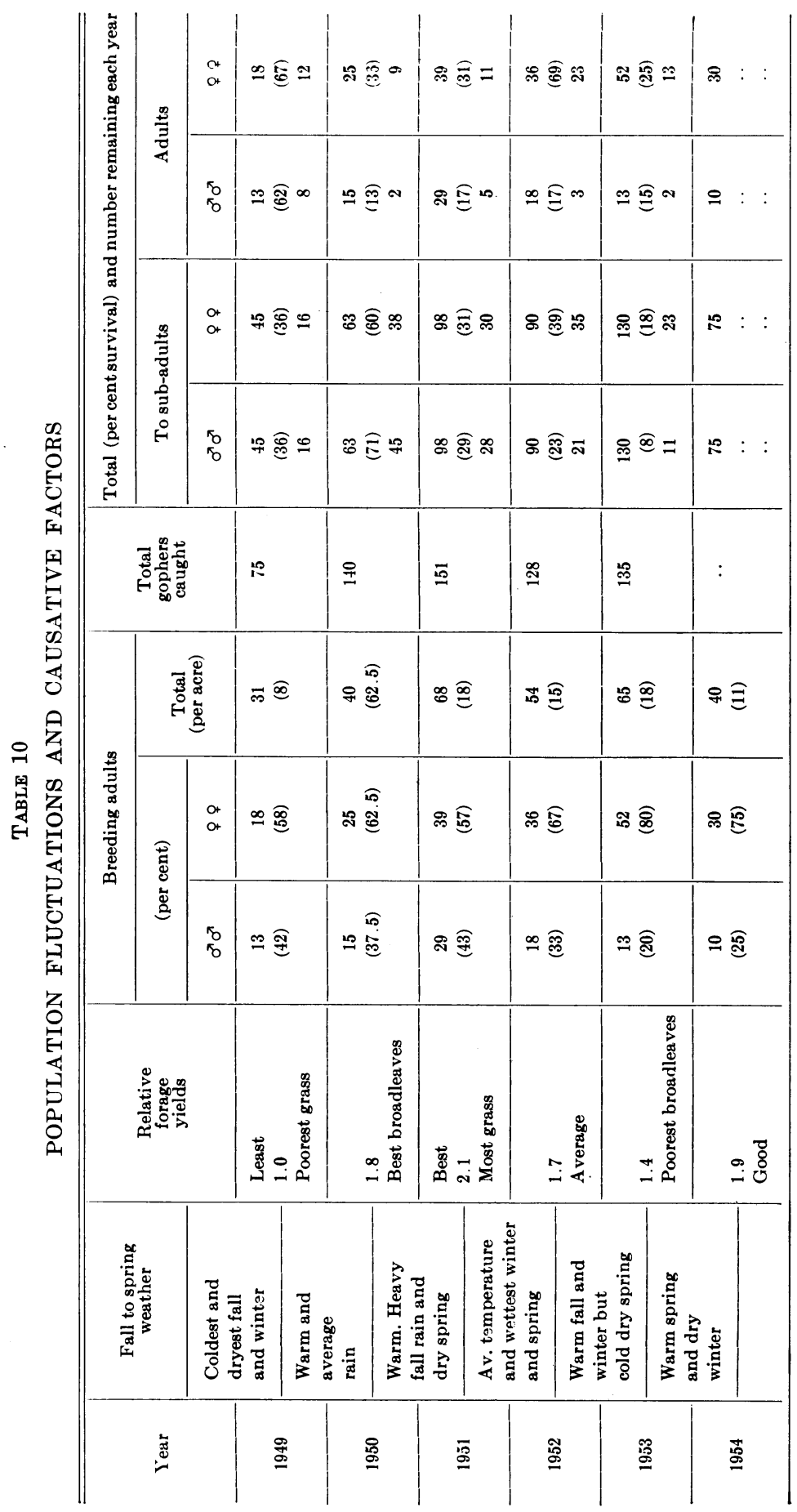


The percentage of males, which are polygamous, that are immatures each year ranged from 71 to 90 , depending upon whether the sex ratio was near $1: 1$ or $1: 4$, respectively.

The carrying capacity or basic adult population on the plot was probably determined by the number of territories the environment could support in the different years. The techniques in this study did not demonstrate a close correlation between territory size and either the amount of forage or the population density, but such a relationship probably exists. For example, when the territory sizes of rangeland gophers of only a few adults per acre are compared with those in irrigated alfalfa fields, where there may be 50 or more adults per acre, it is then clear that territories must be smaller in the better sites that have higher population densities, since the territories do not overlap to any extent. Miller (1957) found the average area occupied by nine gopher territories in flood-irrigated alfalfa to be about 800 square feet, only about 40 per cent the size of those on the plot.

There are frequent instances on rangelands, however, where territoriality has little effect on gopher density. This situation exists when gophers are so few in number that territoriality and gopher density are not interrelated. When gopher densities are so low that much of the available habitat is not utilized, the animals then occur in clusters or even singly. And, of course, there are numerous instances of this type, when something other than current food supply has been responsible for limiting gopher numbers. That food supply is often not the limiting factor of rodent numbers has been pointed out by Chitty (1952 and 1955), Clarke (1955), Godfrey (1955), and others. The authors do not have adequate reproductive data to determine whether or not adverse effects of population density affected the reproductive potential of later generations of gophers, i.e., a lessening of reproductive success of individuals born to parents that had been subjected to unfavorable conditions of stress as proposed by Chitty (ibid.) and discussed by Clarke (ibid.) and Godfrey (ibid.)

Further research is necessary to determine the optimal environmental factors on the plot, but table 10 illustrates some of them. Weather conditions promoting forage include temperature and moisture conditions only from late fall to early spring, for the rest of the year is always warm and dry. The following points are also listed for each year: the number and per cent of breeding adults of each sex; the total number of breeding adults and th? equivalent number on a per acre basis; the total number of individuals of all ages trapped at least once on the plot, including those that moved on or off the plot during that year; the estimated number of gophers of each sex born on plot, by assuming that each adult female averaged five offspring per year, and the actual per cent and number of immatures surviving long enough to be trapped as sub-adults on the plot; and the number of adults of each sex that were yearlings or older and per cent and number of them that survived the year where listed.

The production of annual forage on the plot is clearly important (table 10). With ample rain in early fall while the weather is still warm, the annual plants can germinate and develop a strong root system and sufficient growth 
before winter sets in, to provide food and cover during the winter. Then, if there is sufficient rain in the spring to re-wet the shallow soil after the rapid growth of forage begins, there will be an abundant supply of food and cover available to the gophers.

We have not been able to distinguish between the degree of importance of forage as food and as cover, for to a large degree the same plants serve both purposes. The less food there is available the more exposed are the gophers when they feed or deposit excavated soil at the ground surface and, also, the more frequently will they have to expose themselves in search of food. We think that as a result of this situation predation becomes more significant in determining the population density as the habitat becomes less favorable for gophers. But broadly speaking, as far as its effects on the stability of the "basic" gopher density is concerned, predation of pocket gophers appears to be largely density-proportional, the fewer the gophers the more likely predators are to keep the density below the carrying capacity of the area.

Mortality per se is positively correlated with the favorability of the gopher habitat. The more suitable the habitat is for gophers the higher will be the total mortality rate of gophers per unit area. For example, in less favorable habitats there may be a spring density averaging about one adult female per acre, with an annual mortality rate of about 2.5 (71 per cent) females of all ages per acre; whereas in more favorable habitats, where there may be 30 adult females per acre in the spring, such a favorable ecosystem will then result in over 75 (71 per cent) females of all ages dying annually per acre. Presumably, many of these gophers, which are in surplus to the supply of habitats available, would succumb to predators. If sufficient predation were not present, however, most of them would probably still disappear due to territoriality or other factors. But the percentage of the population available to predators seems to be determined by the rate of fecundity that year and the carryover population density from the previous year, which governs the number of available territories; hence, predation is not always densityproportional but may become density-dependent. However, predation probably never reduces the basic gopher population more than what its realized reproductive potential can replace several-fold the following spring.

There does not seem to be any indication of an overpopulation phenomenon with gophers. Territoriality probably prevents the build-up of an overpopulation of gophers that might be sufficient to cause any sudden reduction in numbers due to overcrowding, damage to the suitability of the environment of gophers, increased susceptibility to disease, creation of a populationinduced food shortage, or an effective increase of enemies. Fluctuations in basic gopher densities are primarily regulated by the adequacy of food and cover, although the mechanism of territoriality in a species where males are polygamous and females live longer will have some influence. Predation, parasites, and disease are subordinate as population controls of gophers on the plot. They may be important mortality factors but they usually are not very significant per se in determining the basic carrying capacity of the habitat.

Interspecific competition between gophers and other animals living on 
or about the plot did not appear to be an important mortality factor. Intraspecific strife in the form of territoriality, on the other hand, is the master population density-controlling factor responding to the effects brought about by the amount of the annual forage produced. Yet, when density is low, intraspecific strife is probably proportionately lower, perhaps due to the mechanics of gophers being restricted to separate burrow systems that are more widely spaced during poor forage years. At least in 1949, following the unfavorable forage production year of 1948-1949 when the gopher density was lowest, the adults then experienced their highest degree of survival. It is not known how the various age classes fared in the winter of 1948 .

Occupation by gophers of less suitable habitats was not a phenomenon associated just with years of high population densities, as the result of an overflow of individuals from favorable niches into the less suitable sites. The productivity, i.e., the realized natality of the gopher population on the plot always appeared adequate to stock all available marginal habitats. What we call "marginal" habitats are sites that are adequate for occupancy during only certain seasons. They are not adequate for year-round habitation with any reasonable degree of security to the animal. They are called marginal only during the time that they are suitable for partial or temporary occupation by gophers, but in other years they may become completely inadequate or unsuitable. Marginal habitats probably serve as a temporary sanctuary until the individual either improves its status or succumbs.

As far as the study plot is concerned, all of the components of its ecosystem as well as the structure of the gopher population are continually in a state of flux. The performance of the gopher population depends not only on its inherent qualities and on the habitat but also on the entire ecosystem of which it is an integral part. To single out various factors and label them as the principal density-controlling forces of the gopher population, as we have done, is dangerous. Even though some factors appear to be the master controls, one must remember that "a chain is no stronger than its weakest link." There are many complex entities that may remain obscure because of compensatory actions that may exist between group attributes of gophers and the physical and biotic factors of their environment. Even though we ascribe weather and its influence on the annual supply of food and cover as being the dominant factor responsible for setting the general level of the annual density of gophers, we think Solomon's (1949) statement has merit: "On the whole, then, it seems there is no certain basis in present knowledge for any very simple generalization about the determinants of the level of density, except that the immediate determinants are all the chief elements of the ecosystem."

Perhaps the best justification we have for suspecting weather and the resulting yield of annual forage as being such an important controlling factor of gopher density is because this is one part of the whole dynamic complex that is highly variable and variability of which is also "understandably" correlated with the variations in gopher numbers. Lack (1954) points out that "the critical mortality factors (food supply, predators, and disease) are density-dependent, hence climate (weather) per se cannot be the primary 
factor controlling numbers." Actually it is often difficult to classify many of the various factors as being either density-dependent, density-proportional or density-independent unless their use is clearly defined in each instance. Even though we recognize the existence of this paradox, we have nevertheless listed these factors in figure 39, in our schematic representation of the integration of the gopher population. We look upon the changes of

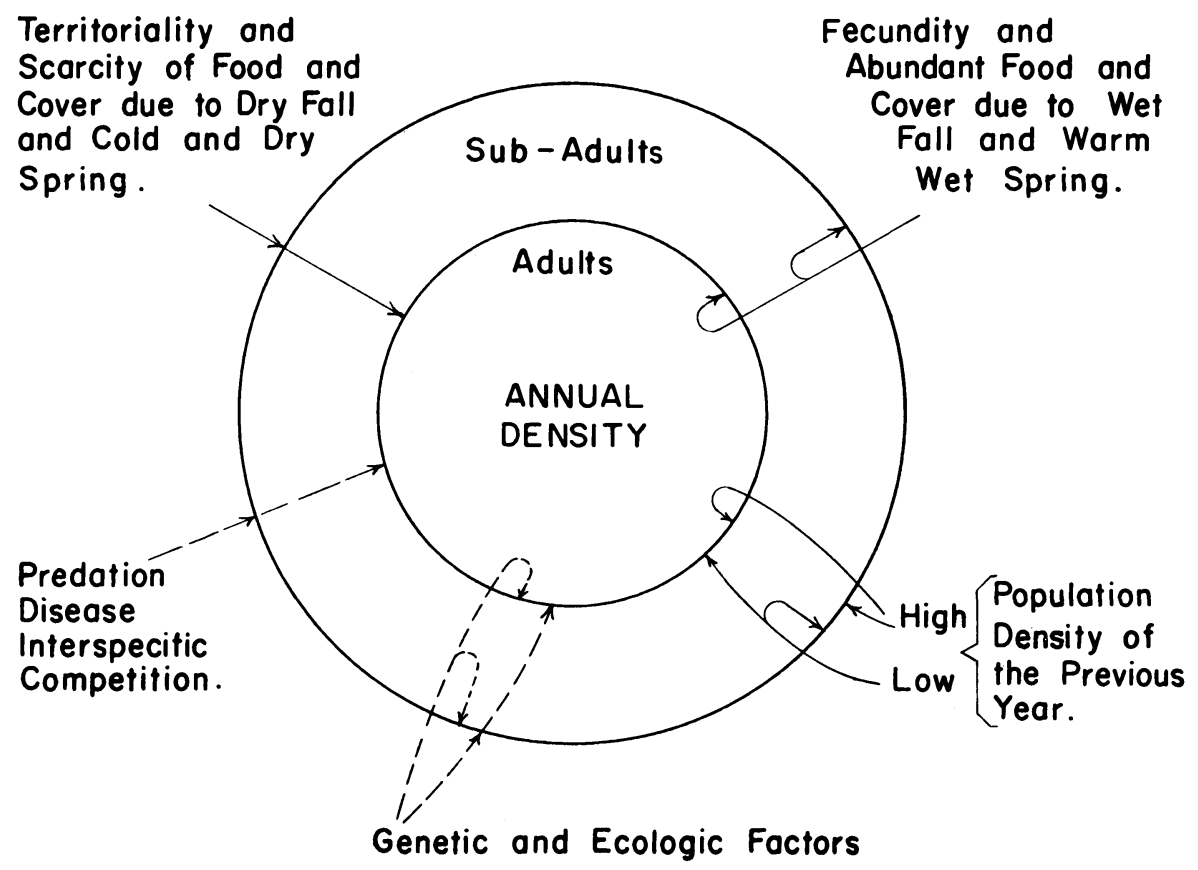

Fig. 39. A schematic representation of the interplay between the primary densitydependent factors that regulate the population structure of pocket gophers on the plot. Genetic and ecologic factors may be either dependent or independent of density. Predation and interspecific competition are probably mostly density-proportional, since we think about the same percentage of gophers is affected except when the population density becomes low, when the factors are then density-dependent.

weather as being dynamic in their effect on the gopher population, since both weather and population change from day to day, yet we are cognizant that climate and density of a population are also both static, in the sense that each has evolved a relative degree of stability when considered over long periods of time.

In the gopher population territoriality per se plays a significant role in regulating the gopher density to take advantage of the occurrence of optimal conditions of the environment without surpassing the limits of tolerance of the habitat. Territoriality functions with the gopher population in the following ways: (1) spaces individuals, resulting in a more stable population organization, which is then primarily determined by weather conditions 
(food and cover) ; (2) tends to limit the breeding population to the ecological carrying capacity of the ecosystem so that adults do not eat themselves out of house and home; (3) helps to insure an adequate year-long food supply by preventing overpopulation and exploitation of the food following breeding, when there is always a surplus of food; (4) provides protection to the immatures from intolerant, nonmaternal adults ; and (5) enables each individual to become very familiar with its restricted home range (tunnel system), which reduces the number of necessary exposures to enemies and aids in escaping from predators.

Our evidence that intraspecific strife, or territoriality, often is an important factor causing mortality is partly based on the fact that the highest rate of survival of the adult gophers occurred in 1949 when the population density was lowest, a year when the spring and previous winter environments had been unfavorable. In the following year of 1950 , when the carrying capacity of the ecosystem was near maximum, the population did not build up at its maximum intrinsic rate of natural increase, although there was the highest rate of survival of immatures that year. Intraspecific strife was particularly evident in 1951, however, due to the high carryover in density from 1950. Intraspecific strife is, of course, clearly either densityproportional or density-dependent, for as the population approaches the current carrying capacity of the habitat, fewer territories are available for subadults so they are probably forced by territoriality into longer periods of exposure to predators and other natural mortality factors. This type of competition is clearly the result of environmental limitations, and that is why irrigated alfalfa fields can support many times as dense gopher populations as are observed on many rangelands. But even though territoriality usually becomes more intense as density increases, a vastly improved habitat following a poor year will allow the density to increase for a while without crowding (territoriality) becoming a significant mortality factor.

\section{FORAGE RELATIONSHIPS}

Fitch and Bentley (1949) studied the use of California annual-plant forage by range rodents in four enclosures at the San Joaquin Experimental Range. One of the rodent enclosures, $1 / 4$ acre in extent, was kept stocked as well as possible with eight male pocket gophers from 1935 to 1943 . During this eightyear period the yield of green forage produced was measured in the gopher enclosure and another pen of similar size but without rodents. This made it possible to conclude that the population of 32 gophers per acre had decreased the potential yield of the $1 / 4$-acre pen, on the average, by 25 per cent. This amounts to 813 pounds dry weight per acre annually. Major difficulties in sampling and other problems made it impossible to measure the additional amount of herbage lost during the long dry-forage season.

The penned pocket gophers had no apparent effect on the composition of the herbaceous forage. It should be pointed out, however, that these effects cannot be evaluated easily because of the wide fluctuations from year to year in the abundance of most plant species as a result of annual weather differ- 
ences. Furthermore, some difficulties in interpretation were encountered because sites in the different pens were not equally favorable to all plant species. Since the density of pocket gophers at the Range is perhaps 4 to 10 times that of ground squirrels, gophers compete with livestock for forage more than do squirrels.

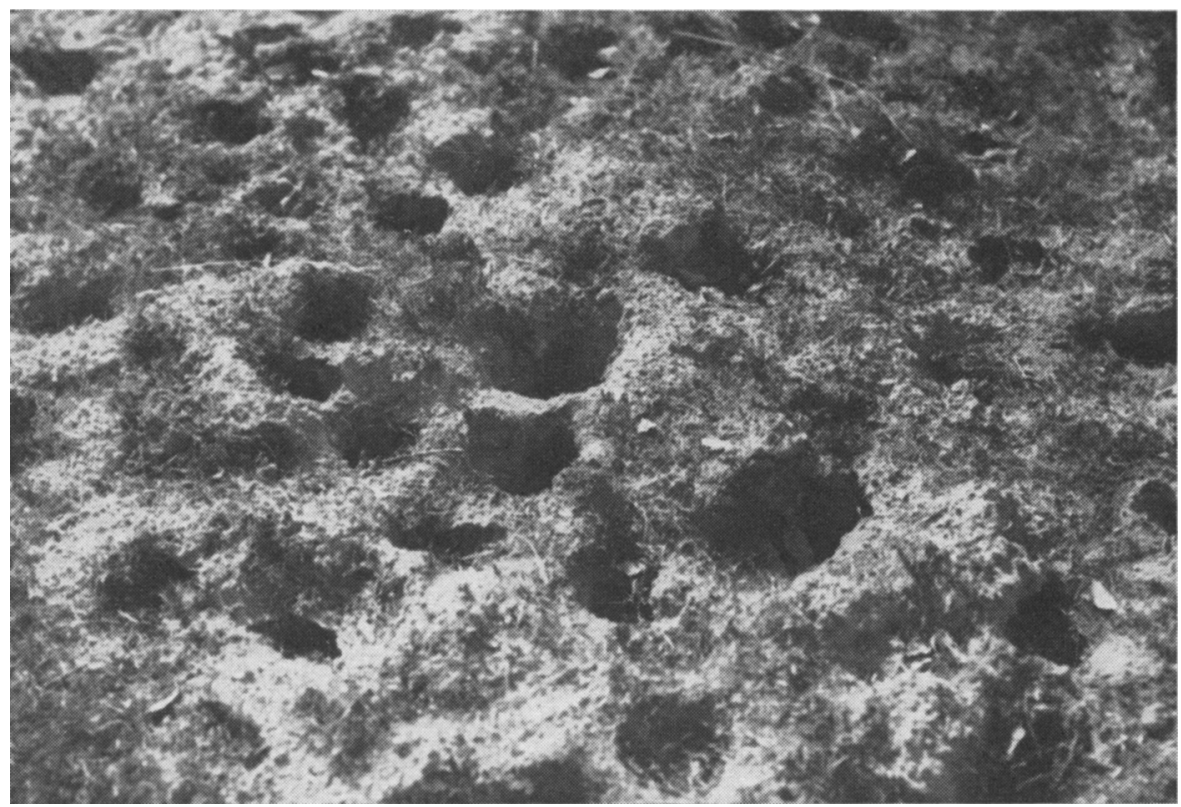

Fig. 40. A portion of an ungrazed swale at the San Joaquin Experimental Range that was examined daily, which would have had a dense stand of herbaceous vegetation if pocket gophers had not consumed practically all the forage. Note numerous gopher "feed holes" and how these animals do not select desirable plants but gather practically all the forage within reach of a feed hole. They usually keep their tail and hind feet in the burrow entrance while gathering forage. When the dry forage in this swale was burned, the number of gophers was greatly reduced. It is not known, however, how much this reduction in gophers was due to a loss of food and how much from loss of cover.

One of the best studies designed to appraise the relation of pocket gophers to mountain meadows was conducted on Thomomys talpoides quadratus by the U.S. Fish and Wildlife Service and U.S. Forest Service (Moore and Reid, 1951). This seventeen-year investigation indicates that artificial control of the Dalles pocket gopher is sometimes necessary. In addition to making available to livestock or game the forage the gopher would use or destroy, gopher control appears to be essential as a range management practice if infested mountain meadows that are in poor range condition are to be improved. While the increase in forage value due to gopher control was found to be slow, the estimated cost of control measures was amortized within a few years. Beginning with the fifth year, the value of the increased grazing capacity for any one year was then equal to, or greater than, the estimated 
cost of control. A contrary view is held by Ingles (1952), who suggests that gophers in mountain meadows may actually be of benefit economically. Ellison (1954) says that the gopher is "a potent factor in speeding accelerated erosion." However, he does not think the gopher is a primary cause of accelerated erosion on the Wasatch Plateau, Utah.

Experiments at the San Joaquin Experimental Range have shown that the quality of forage, which is essentially an annual-plant type, deteriorates when completely protected from grazing. If ungrazed, the forage cover tends to progress for an indefinite period through annual grass stages to become dominated by tall grasses, such as ripgut brome (Bromus rigidus Roth) and slender wild oats (Avena barbata Brot.) (Talbot and Biswell, 1942). These species are coarse and relatively unpalatable to livestock. "Under light to close utilization by cattle, an earlier stage of succession is maintained with a more desirable mixture of species, including clovers and filarees" (Bentley and Talbot, 1948). Observations on the natural area at the Range, which has not been grazed by cattle since 1934, indicates that rodents and other wildlife are unable to maintain this earlier stage of succession without the assistance of cattle except on low-productive sites of shallow soil and around the margins of brush plants (Howard, 1953c).

Since at the Experimental Range moderate degrees of grazing by cattle tend to maintain the forage in an earlier stage of succession, which is more palatable to livestock than the forage on the protected areas, one might erroneously suspect that grazing would bring about an increase in gophers as has been reported for mountain meadows and other types of ranges (Bond, 1945 ; Buechner, 1942 ; Garlough, 1937 ; and Moore and Reid, 1951). The increase in tap-rooted and bulbous-rooted plants may explain the increase in gophers on some deteriorated ranges. Perhaps the reason there are fewer gophers on grazed pastures at the Experimental Range is that there are not enough weedy plants, not taken by cattle, to provide much food or cover for gophers. Gophers at the Range sometimes consume most of the forage that is produced on ungrazed areas (fig. 40).

\section{Effect of Burrows}

The total effect of gopher burrows and digging by gophers on the ecology of an area is far from completely understood (Taylor, 1935). If soil is deep enough for burrowing, yet so shallow because of hardpan that root growth is restricted, gopher burrowing may result in the creation of mima mounds or hogwallows (Arkley and Brown, 1954 ; Price, 1949 ; Scheffer, 1947; and Dalquest and Scheffer, 1942).

Examples of another type of mound construction by gophers occurred on the plot and elsewhere on the Experimental Range. Wherever fallen brush provided good cover, gophers took advantage of this protection when depositing their excavated soil. This resulted in construction of mounds a foot or more high and several feet in diameter. These mounds persist for many years, even after the original brush cover has been burned or otherwise removed. Gophers also take advantage of boxes or barrels turned upside down on the ground to deposit excavated soil in a place protected from predators. 
The vulnerability to predation while pushing excavated soil aboveground may partly explain, along with diminished food supply, why there are fewer gophers at the Range on closely grazed pastures than on those grazed only moderately close.

Since Miller (1957) found that pocket gophers in irrigated alfalfa per day bring an average of 5.13 pounds of soil dry weight to the surface, the belief is often expressed that perhaps such burrowing activity improves soil conditions for plant growth by increasing aeration, water percolation, fertilization, and other cultivation activities. Unfortunately, this subject is a difficult one to test experimentally, and there may be instances of which we are unaware where the digging activity of gophers can actually be considered beneficial. It appears, however, that plant roots and the myriad bacteria, protozoans, worms, crustaceans, arachnids, insects, and other small animals in the soil my accomplish a more desirable form of soil conditioning than do gophers.

The loose earth brought up and piled in crescent or delta-shaped mounds on the surface of the ground by the gopher becomes available for transportation by water. Rain and melted snow carry some of this loose soil down slopes, and in the course of centuries, it contributes to the great and fertile valleys below. So, from a geological standpoint, the pocket gopher may actually have a prior claim to the agricultural land where he is now so unwelcome. Unfortunately, man is now anxious to slow up this natural erosion process, especially the erosion of rich farm lands, and gophers do contribute to soil erosion and gully formation (Crouch, 1942 ; Day, 1931; and Grinnell, $1923)$.

On some soils, when rain water is channeled down gopher burrows subsurface erosion ensues. This happens most frequently where an unusually large amount of water has accumulated along a roadway or in a livestock trail. After the tunnels become enlarged, the tops eventually cave in and deep gullies are formed. On both tilled and untilled lands in parts of California many gullies have originated in this manner. Close grazing is often mistakenly blamed for such erosion, since once the gully has been formed, one can no longer recognize that a gopher started the erosion. This same phenomenon occurs with ground squirrels.

\section{Importance to Man}

Pocket gophers can cause great economic loss to the farmer (Miller, 1953, and Storer, 1953), particularly in the western United States, where man has augmented their food supply and improved conditions for their existence through cultivation and irrigation. This land use occasionally provides so suitable a habitat that pocket gophers become very numerous; in alfalfa fields, for example, the senior author has seen instances of 50 or more breeding adults per acre and there are many instances where the numbers are probably several times this many when sub-adults are included. On the annual-type ranges in California, grazing will sometimes bring about a reduction in pocket gophers, but in mountain meadows and elsewhere the reverse is apparently more common. 
In California, the gopher now rates as the state's most important fieldrodent pest. One animal can be both annoying and costly when its burrowing activity causes water to escape from an earthen reservoir or irrigation ditch, allowing the water to go where it is not wanted. Gophers cause further deterioration and hamper improvement of mountain meadows already in poor range condition (Moore and Reid, 1951). As a species, they can compete with livestock for range forage more vigorously than ground squirrels (Fitch and Bentley, 1949). Gophers spread weeds (Cook, 1939; Crouch, 1942; Day, 1931; and Ellison, 1946). Their extensive burrowing activities and incessant gnawing (Howard, 1953a) make them a serious pest, one that no home gardener, in particular, will tolerate.

In the light of the technical developments now applied to the science of agriculture, any beneficial effects pocket gophers might exert on California rangelands can hardly be credited as being of any significance, even on these untilled lands. In fact, their control, where necessary, appears to be good conservation. Nevertheless, at least from an academic point of view, all potential beneficial attributes of rangeland gophers are of considerable interest, for we want to be certain that none has been overlooked.

\section{SUMMARY}

From the fall of 1947 to the summer of 1954, the life history of the Digger pine pocket gopher (Thomomys bottae mewa) was investigated at the San Joaquin Experimental Range, O'Neals, California. More than 1,000 gophers were handled. Most of the information about the population dynamies of gophers was obtained by live-trapping 330 marked individuals 1,798 times on a 3.7 acre study plot. This repeated live-trapping lasted for five years. Others were maintained in laboratory cages. Gophers live a solitary existence except during the breeding season when multiple captures occurred in the same burrow. Few of the females were breeding before they were one year old. A few females produced two litters a season, but generally they had only one litter, usually in February or March. The best external characteristic for indicating breeding activity in females, according to 222 that were autopsied, is a swollen or open vagina.

Body weight is not a reliable indication of age. Males continue to grow throughout their life. Weights of live-trapped gophers changed from +0.75 to -1.14 grams per hour while confined in a trap. One female lived for another year after losing 22.5 per cent of her weight when held in a trap with insufficient food for 20 hours. This is easy to understand, however, for the weight of the alimentary tract of seven gophers (T. b. navus) averaged about one fifth (18.1 to 25.7 per cent) of their gross body weight.

It is not uncommon for females to live as long as three or four years. More than half of the female gophers reaching the age of one year also live to be two years old, except when the population density is high and the turn-over, consequently, more rapid. Males do not live as long as females.

Our data indicate that gophers are polygamous. The adult sex ratio of males to females varied from about $1: 1$ to $1: 4$. Females predominated (1:4) when the population density was high. 
The home range of a pocket gopher is also its "territory," for adults vigorously defend their entire burrow system from individuals of both sexes, except for brief periods during the breeding season. Male territories occupied an average surface area of 2,700 square feet, whereas females only one half that, or 1,300 square feet.

During March, April, and May juveniles left home, to become sub-adults, by often traveling aboveground in their dispersal movement. More than 200 sub-adults were captured in funnel traps placed on the ground surface along hardware-cloth drift fences.

Gophers often seem instinctively capable of returning home when released in other burrows 200 feet or more away. They apparently return by traveling through existing burrow systems, passing through the territories of other gophers. Individuals released on the opposite side of a drift fence returned without getting caught in traps along the fence and without digging under the wire fence.

Attempts to correlate soil and forage conditions with gopher distribution and weights in a cause-and-effect relation are discussed.

No ticks, fleas, or warbles were found on gophers at the Experimental Range, which seems unusual. However, one species of louse, three kinds of mites, and tapeworms were found.

The ecological factors responsible for creating fluctuations in the density of gophers are discussed. Also the significance of pocket gophers with respect to animal associates, forage relationships, effect of burrows, and importance to man is discussed.

\section{ACKNOWLEDGMENTS}

Acknowledgments are due many people in addition to those listed below. We are especially grateful to Superintendents Fred D. Douthitt and, later, Charles A. Graham of the San Joaquin Experimental Range, and others of the Pacific Southwest Forest and Range Experiment Station, U.S. Forest Service, for the opportunity of centering this research project at the Range, for the housing they provided, and for the many courtesies afforded us.

Gordon L. Huntington both directed and materially assisted in the soil survey of the pocket gopher study plot. The forage survey was guided and assisted by Lisle R. Green. Morton T. Swarth helped survey the plot. The U.S. Fish and Wildlife Service made available information about the gopher burrows that Everett E. Horn had excavated at the San Joaquin Experimental Range in the 1930's. Seth B. Benson made available the gopher specimens in the Museum of Vertebrate Zoology at Berkeley, which had been collected from localities near the study area. Oliver P. Pearson has given much advice regarding the reproductive data. Identifications of parasites were made by Marietta Voge, Sherwin F. Wood, and E. W. Jameson, Jr.

The manuscript has been read critically, in part or in entirety, by S. B. Benson, R. S. Miller, M. A. Miller, R. M. Hansen, and O. P. Pearson. This study was initiated in 1947 by the senior author, but most of the field work on the study plot was done by Jay C. Quast in 1949-50, by Nathan W. Cohen in 1950-51, and by the junior author from 1951 to 1954 . Formerly, while 
the field work was under way, the authors were members of the faculty and staff, respectively, of the Department of Zoology, University of California, Davis.

\section{LITERATURE CITED}

Allee, W. C., A. E. Enerson, O. Park, T. Park, and K. P. Schmidt

1949. Principles of animal ecology. W. B. Saunders Co., 837 pp.

ANDREWARTHa, H. G., and L. C. Birch

1954. The distribution and abundance of animals. University of Chicago Press, $782 \mathrm{pp}$.

ARKLEY, R. J., and H. C. BRow N

1954. The origin of mima mound (hogwallow) microrelief in the far western states. Soil Sci. Soc. Amer. Proc. 18:195-99.

Bentley, J. R., and M. W. TAlbot

1948. Annual plant vegetation of the California foothills as related to range management. Ecology 29:72-79.

1951. Efficient use of annual plants on cattle ranges in the California foothills. U.S. Dept. Agr. Cir. 870, 52 pp.

BLAIR, W. F.

1941. Techniques for the study of mammal populations. Juur. Mammal. 22:148-57.

BoND, R. M.

1945. Range rodents and plant succession. Trans. 10th North Amer. Wildlife Conf., pp. 229-34.

BRYANT, H. C.

1913. Nocturnal wanderings of the California pocket gopher. University California Publ. Zool. 12:25-29.

BUECHNER, H. K.

1942. Interrelationships between the pocket gopher and land use. Jour. Mammal. 23: $346-48$.

Childs, H. E., JR., and W. E. Howard

1955. The vertebrate fauna of San Joaquin Experimental Range. California Forest and Range Exp. Sta., Misc. Paper No. 19. 20 pp.

Chitтty, D.

1952. Mortality among voles (Microtus agrestis) at Lake Vyrnevy, Montgomeryshire in 1936-9. Roy. Soc. London Phil. Trans. 236 (B 638):505-52.

1955. Adverse effects of population density upon the viability of later generations. Pp. 57-67, In The numbers of man and animals. Ed. by J. B. Cragg and N. W. Pirie. Oliver and Boyd Ltd. for the Inst. of Biology, Edinburgh, Scotland, $152 \mathrm{pp}$. Clarke, J. R.

1955. Influence of numbers on reproduction and survival in two experimental vole

Cook, J. B. populations. Royal Soc. Proc. Ser. B, 144:68-85.

1939. Pocket gophers spread Canada thistle. California Dept. Agr. Bul. 28:142-43.

Crouch, W. E.

1942. Pocket gopher control. U.S. Fish and Wildlife Service Conservation Bul. 23, 20 pp.

DALquest, W. W., and V. B. ScheFFER

1942. The origin of the mima mounds of western Washington. Jour. Geol. 50:68-84.

DAY, A. M.

1931. Soil erosion is often caused by burrowing rodents. U.S. Dept. Agr. Yearbook

DICE, L. R. 1931, pp. 481-84.

1952. Natural communities. University Michigan Press, $547 \mathrm{pp}$.

Dice, L. R., and W. E. Howard

1951. Distance of dispersal by prairie deermice from birth places to breeding sites. University Michigan Contrib. Lab. Vert. Biol. No. 50, 15 pp. 
DiCE, L. R., and H. J. LeraAs

1936. A graphic method for comparing several sets of measurements. University Michigan Contrib. Lab. Vert. Genetics No. 3, 3 pp.

Ellison, L.

1946. The pocket gopher in relation to soil erosion on mountain range. Ecology 27: 101-14.

1954. Subalpine vegetation of the Wasatch Plateau, Utah, Ecological Monographs 24: 89-184.

EmLen, J. T., JR.

1944. Device for holding live wild rats. Jour. Wildlife Mangt. 8:264-65.

English, P. F.

1932. Some habits of the poeket gopher, Geomys breviceps breviceps. Jour. Mammal. 13:126-32.

Errington, P. L.

1946. Predation and vertebrate populations. Quart. Rev. Biol. 21:144-77, 221-45.

Evans, F. C.

1956. Ecosystem as the basic unit in ecology. Science 123(3208):1127-28.

FARNER, D. S.

1945. Age groups and longevity in the American robin. Wilson Bul. 57:56-74.

Fiтch, H. S.

1940. Some observations on horned owl nests. Condor 42:73-75.

1947. Predation by owls in the Sierra foothills of California. Condor 49: 137-51.

1948. A study of coyote relationships on cattle range. Jour. Wildlife Mangt. 12:73-78.

1949. Study of snake populations in central California. Amer. Midland Nat. 41:513-79.

FiTCH, H. S., and J. R. BENTLEY

1949. Use of California annual-plant forage by range rodents. Ecology 30:306-21.

Fitch, H. S., F. Swenson, and D. F. Tillotson

1946. Behavior and food habits of the red-tailed hawk. Condor 48:205-37.

Fitch, H. S., and H. Twining

1946. Feeding habits of the Pacific rattlesnakes. Copeia (2) :64-71.

Garlough, F. E.

1937. Research studies in the control of destructive mammals. Trans. 2d North Amer. Wildlife Conf., pp 303-10.

GODFREY, G. K.

1955. Observations on the nature of the decline in numbers of two Microtus populations. Jour. Mammal. 36:209-14.

GRINNELL, J.

1923. The burrowing rodents of California as agents in soil formation. Jour. Mammal. 4:137-49.

1933. Review of the recent mammal fauna of California. University California Publ. in Zool. 40 (2) : 71-234.

GunTHER, W. C.

1956. Studies on the male reproductive system of the California pocket gopher (Thomomys bottae navus Merriam). Amer. Midland Nat. 55:1-40.

HILL, J. E.

1937. Morphology of the pocket gopher mammalian genus Thomomys. University of California Publ. Zool. 42:81-171.

HisAw, F. L.

1924. The absorption of the pubic symphysis of the pocket gopher, Geomys bursarius (Shaw). Amer. Nat. 58:93-96.

1925. The influence of the ovary on the resorption of the pubic bones of the pocket gopher, Geomys bursarius (Shaw). Jour. Expt. Zool. 42:411-33.

Holliger, C. D.

1916. Anatomical adaptations in the thoracic limb of the California pocket gopher and other rodents. University California Publ. Zool. 13:447-94.

Hooper, E. T.

1941. Type localities of pocket gophers of the genus Thomomys. University Michigan Mus. Zool. Misc. Publ. No. 52, 26 pp. 
HowARD, W. E.

1949. Dispersal, amount of inbreeding and longevity in a local population of prairie deermice on the George Reserve, southern Michigan. University Michigan Contrib. Lab. Vert. Biol. No. 43, 52 pp.

1951. Relation between low temperature and available food to survival of small rodents. Jour. Mammal. 32:300-12.

1952. A live trap for pocket gophers. Jour. Mammal. 33:61-65.

1953a. Tests of pocket gophers gnawing electric cables. Jour. Wildlife Mangt. 17: 296-300.

1953b. Growth rate of nails on adult pocket gophers. Jour. Mammal. 34:394-96.

1953c. Rodent control on California ranges. Jour. Range Mangt. 6:423-34.

HowaRD, W. E., and L. G. INGLES

1951. Outline for an ecological life history of pocket gophers and other fossorial mammals. Ecology 32:537-44.

HowARD, W. E., and M. E. SMITH

1952. Rate of extrusive growth of incisors of pocket gophers. Jour. Mammal. 33:485-87.

Howell, A. B.

1922. Surface wanderings of fossorial mammals. Jour. Mammal. 3:19-22.

Hutchison, C. B., and E. I. Коток

1942. The San Joaquin Experimental Range. California Agr. Exp. Sta. Bul. 663. 145 pp. IMLER, R. H.

1945. Bullsnakes and their control on a Nebraska wildlife refuge. Jour. Wildlife Mangt. 9:265-73.

INGLES, L. G.

1952. The ecology of the mountain pocket gopher, Thomomys monticola. Ecology 33 (1) : 87-95.

KeLLY, A. O.

1948. The mima mounds. Sei. Monthly $66: 174-75$.

LACK, D.

1954. The natural regulation of animal numbers. Oxford at Clarendon Press, $343 \mathrm{pp}$.

MerRiam, C. H.

1906. Monographic revision of the pocket gophers, family geomyidae, exclusive of the species of Thomomys. North Amer. Fauna No. 8, 262 pp.

Miller, M. A.

1946. Reproductive rates and cycles in the pocket gopher. Jour. Mammal. 27:335-58.

1952. Size characteristics of the Sacramento Valley pocket gopher (Thomomys bottae navus Merriam). Jour. Mammal. $33: 442-56$.

1953. Experimental studies on poisoning pocket gophers. Hilgardia 22(4) :131-66.

1957. Burrows of the Sacramento Valley pocket gopher in flood-irrigated alfalfa fields. Hilgardia 26 (8) :431-52

MOORE, A. W., and E. H. REID

1951. The Dalles pocket gopher and its influence on forage production of Oregon mountain meadows. U. S. Dept. Agr. Cir. 884. 36 pp.

MOREJOHN, G. V., and W. E. HOWARD

1956. Molt in pocket gopher, Thomomys bottae. Jour Mammal. 37:201-13.

ODUM, E. P.

1953. Fundamentals of ecology. W. B. Saunders Co. 384 pp.

Price, W. A.

1949. Pocket gophers as architects of mima (pimple) mounds of the western United States. Texas Jour. Sci. 1:1-17.

SAGAL, BERNICE E.

1942. Natural history of the pocket gopher, Thomomys bottae, of Alameda County, California. Thesis (M.A.) University California Library, Berkeley. 92 pp.

SCHEFFER, T. H.

1945. Burrow associations of small mammals. Murrelet $26: 24-26$.

1954. Concerning the pocket gopher in mole range. Wash. Agr. Exp. Sta. Cir. 242. 4 pp.

SCHEFFER, V. B.

1947. The mystery of the mima mounds. Sci. Monthly $65: 283-94$. 
SMith, Alfred

1929. Daily and seasonal air and soil temperatures at Davis, California. Hilgardia $4(3): 77-112$.

Solomon, M. E.

1949. The natural control of animal populations. Jour. Anim. Ecology 18:1-35.

STORER, T. I.

1953. Controlling field rodents in California. California Agr. Exp. Sta. Cir. 434. 47 pp.

TALBOT, M. W., and H. H. Biswell

1942. The forage crop and its management. California Agr. Exp. Sta. Bul. 663:13-49.

TAlbot, M. W., J. W. Nelson, and R. E. STORIE

1942. The experimental area. California Agr. Exp. Sta. Bul. 663:7-12.

TAYLOR, W. P.

1935. Some animal relations to soils. Ecology $16: 127-36$.

Tevis, L., JR.

1955. Observations on chipmunks and mantled squirrels in northeastern California. Amer. Midl. Nat. 53:71-78.

TRYoN, C. A., JR.

1947. The biology of the pocket gopher, Thomomys talpoides in Montana. Montana State Coll. Agr. Exp. Sta. Tech. Bul. 448:1-30.

Wight, H. M.

1930. Breeding habits and economic relations of the Dalles pocket gopher. Jour. Mammal. $11: 40-48$. 


\section{CONTENTS}

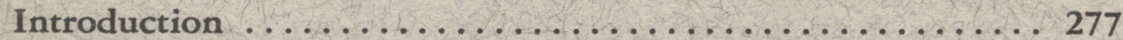

General characteristics and behavior of gophers........ 278

The Digger pine pocket gopher................. 281

The study area.......................... 281

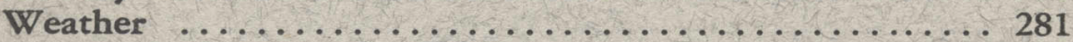

Vegetation $\ldots \ldots \ldots \ldots \ldots \ldots \ldots \ldots \ldots \ldots \ldots \ldots . \ldots \ldots 28$

Methods ............................. 284

The field plot $\ldots \ldots \ldots \ldots \ldots \ldots \ldots \ldots \ldots \ldots \ldots \ldots . \ldots \ldots$

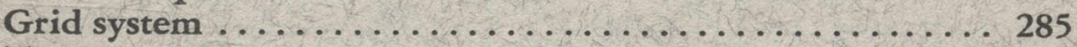

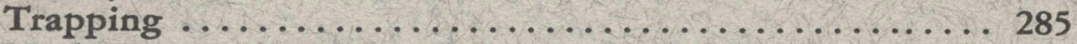

Marking and recording ..................... 288

Capture frequency........................ 289

Age criterion ........................... 293

Reproduction........................... 294

Body growth and weights..................... 298

Longevity ........................... 302

Dispersal............................ 312

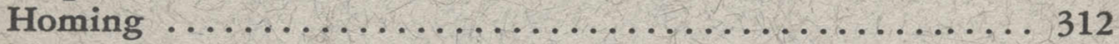

Territoriality ........................... 316

Habitat factors regulating distribution of territories....... 329

Soil ................................. 329

Soil temperature ........................ 332

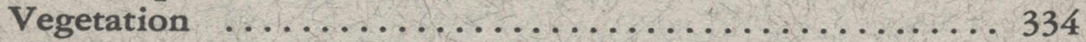

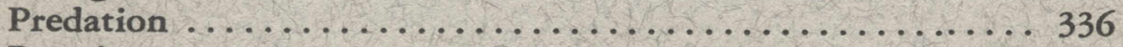

Parasites . . . . . . . . . . . . . . . . . . . . . . 338

Animal associations ........................ 338

Discussion ............................. 338

Population fluctuations $\ldots \ldots \ldots \ldots \ldots \ldots \ldots \ldots \ldots \ldots . \ldots \ldots$

Forage relationships $\ldots \ldots \ldots \ldots \ldots \ldots \ldots \ldots \ldots \ldots \ldots . \ldots \ldots$

Effect of burrows ....................... 351

Importance to $\operatorname{man} \ldots \ldots \ldots \ldots \ldots \ldots \ldots \ldots \ldots \ldots, 352$

Summary .............................. 353

Acknowledgments...................... 354

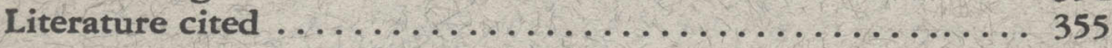


The journal Hilgardia is published at irregular intervals, in volumes of about 600 pages. The number of issues per volume varies. Subscriptions are not sold. The periodical is sent as published only to libraries, or to institutions in foreign countries having publications to offer in exchange.

You may obtain a single copy of any issue free, as long as the supply lasts; please request by volume and issue number from:

$$
\begin{aligned}
& \text { Agricultural Publications } \\
& 207 \text { University Hall } \\
& 2200 \text { University Avenue } \\
& \text { Berkeley 4, California }
\end{aligned}
$$

The limit to nonresidents of California is 10 separate issues on a single order. A list of the issues still available will be sent on request. 